\title{
ipen
}

INSTITUTO DE PESQUISAS ENERGÉTICAS E NUCLEARES

Autarquia associada à Universidade de São Paulo

\section{ESTUDO DE TRATAMENTO QUÍMICO DE URINA PARA REDUÇÃO NO CONSUMO DE ÁGUA EM DESCARGAS RESIDENCIAIS}

\section{ANTONIO CÉSAR TEIXEIRA DE TOLEDO}

Dissertação apresentada como parte dos Requisitos para obtenção de Grau de Mestre em Ciências na Área de Tecnologia Nuclear - Materiais.

Orientadora:

Prof. a Dra Elâine Arantes Jardim Martins

São Paulo

2013 
À minha familia, em especial aos meus pais pelo amor e carinho em todos os momentos de minha vida. 


\section{AGRADECIMENTOS}

À Deus por me guiar e ter me fortalecido nos momentos mais difíceis.

Ao meu pai e minha mãe por todo apoio, carinho e conselhos, mas, sobretudo por todo o amor a mim dispensado.

Ao professor Flávio Gramolelli Júnior pela parceria, amizade, confiança e pela grande contribuição para realização deste trabalho.

À professora Lucilena Rebelo por ter feito parte de minha formação e pela ajuda em parte deste projeto.

Às amigas do CQMA, em particular à Joyce por ter sido meu manual de sobrevivência acadêmica durante os momentos turbulentos, além dos conselhos, dicas, amizade e por ter me incentivado quando mais precisei, e à Juliana Otomo pelas preciosas dicas e por toda simpatia.

De maneira muito especial agradeço ao Dr. Hélio Akira por ter sido o grande incentivador deste trabalho e ter me ajudado a desenvolver toda a pesquisa com suas ótimas ideias, além de contribuir na minha formação profissional e pessoal.

À professora Elâine Arantes pelo privilégio de tê-la como minha orientadora neste trabalho, pois suas contribuições foram muito além do texto aqui escrito. Tive segurança, confiança e apoio em todos os momentos que precisei, fundamentalmente naqueles mais difíceis.

Aos funcionários do IPEN e do CQMA pela amizade, dedicação e disponibilidade. Em especial ao técnico Elias por todo bom humor e alegria contagiante.

À FAPESP pelo apoio financeiro ao projeto PIPE 2010/50224-4. 
"A persistência é o menor caminho do êxito".

Charles Chaplin 


\title{
ESTUDO DE TRATAMENTO QUÍMICO DE URINA PARA REDUÇÃO NO CONSUMO DE ÁGUA EM DESCARGAS RESIDENCIAIS
}

\section{ANTONIO CÉSAR TEIXEIRA DE TOLEDO}

\begin{abstract}
RESUMO
O presente estudo propõe uma alternativa para tratamento químico da urina para redução no consumo de água em descargas residenciais, possibilitando um maior tempo de permanência da água a ser descartada na bacia sanitária antes do acionamento da descarga. O processo consiste em neutralizar os componentes responsáveis pelo odor e cor característicos da urina a partir da reação química com dicloroisocianurato de sódio, NaDCC. O composto também apresenta ação bactericida podendo agir por um determinado período de tempo. Além disso, considera-se a adição de um componente indicador de nível de saturação do meio para otimizar o efeito sobre os aspectos estéticos e sanitários (odor, cor e presença de bactérias). O tratamento proposto deverá apresentar baixo custo estimulando a mudança de paradigmas por meio da conscientização da importância da redução do consumo de água nas residências. Pretende-se acompanhar o desempenho do processo proposto a partir de ensaios físicoquímicos e microbiológicos.
\end{abstract}




\title{
CHEMICAL TREATMENT OF URINE USING A SANITARY TABLET TO REDUCE WATER USAGE IN RESIDENTIAL TOILETS
}

\section{ANTONIO CÉSAR TEIXEIRA DE TOLEDO}

\begin{abstract}
The following work proposes an alternative to reduce water consumption in residential toilets by treating urine chemically, making it possible to wait longer until actually flushing the toilet. The process consists in using a tablet capable of neutralizing the components responsible for urine's smell and color by reacting them with the tablet's main component, Sodium dichloroisocyanurate, NADCC, which also is an antibacterial agent, being able to remain active for a certain period of time. Besides, the addition of an environment saturation indicator is proposed to optimize the effects over the aesthetic and sanitary - odor, color and bacterial presence - aspects. The process includes the advantage of having a low cost, stimulating the change of certain paradigms by inducing people to acknowledge the importance of reducing water consumption at their houses.
\end{abstract}




\section{SUMÁRIO}

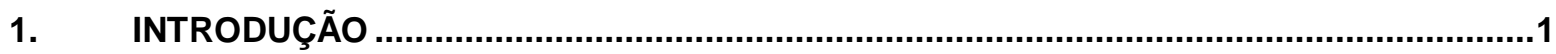

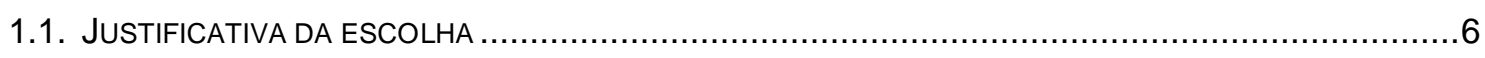

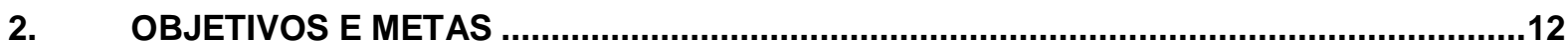

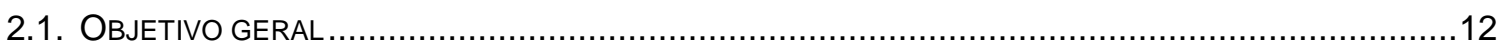

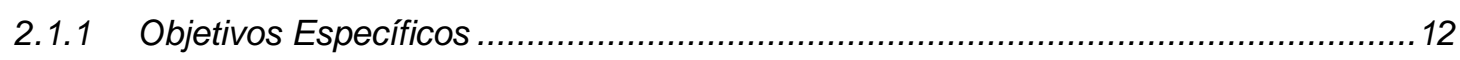

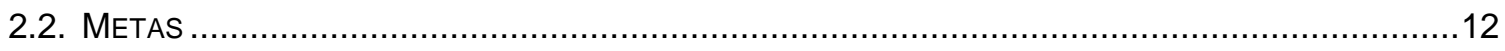

3. APORTE FINANCEIRO

3.1. Projeto fapesp: Estudo da Redução de Consumo de água em Descargas ResidencIaIS. Projeto PIPE-FAPESP-PROCESSO 10/502244 .......................................13

4. REVISÃO DA LITERATURA

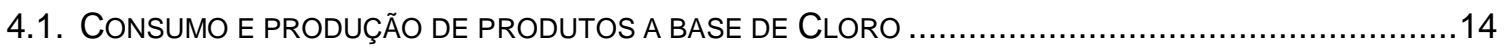

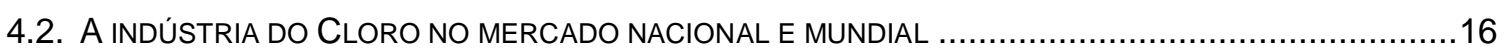

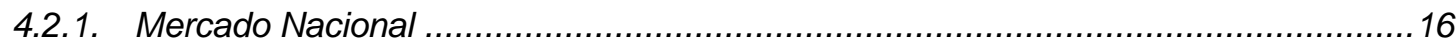

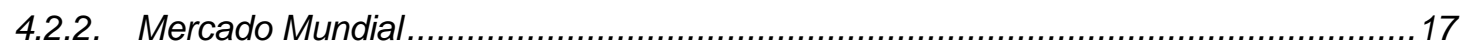

4.3. Crescimento em volume e faturamento de produtos para limpeza a base de Cloro......18

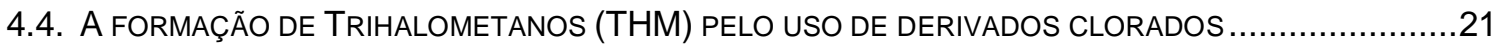

4.5. PROdutos À BASE DE CLORO UTILIZADOS EM OUTROS PAíSES COM FINALIDADE DE DESINFECÇÃO

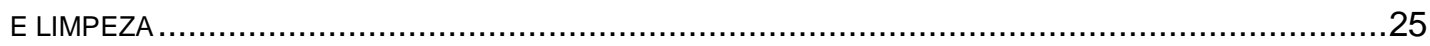

4.6. INFORMAÇÕES GERAIS SOBRE PRODUTOS SANEANTES - LEGISLAÇÃO BRASILEIRA .....................26

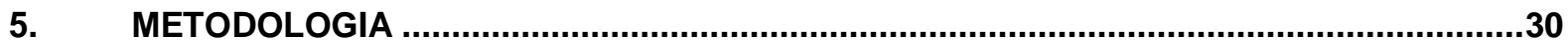

5.1. METOdologIA DO PROCESSO PARA PRODUÇÃO DE COMPRIMIDO SANITIZANTE ............................31

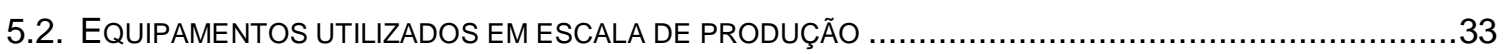

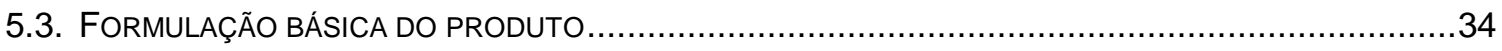

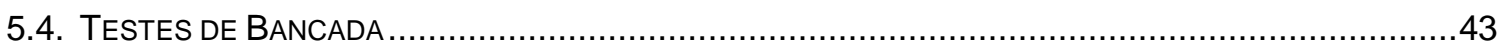

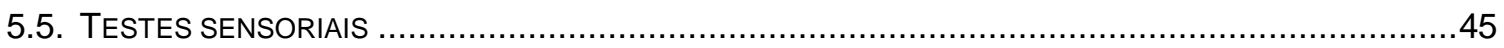

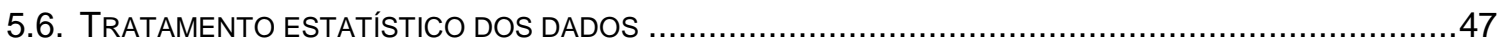

6. RESULTADOS E DISCUSSÃO

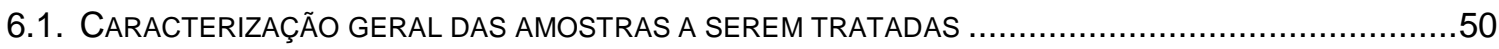

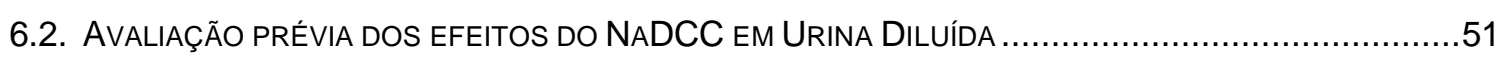

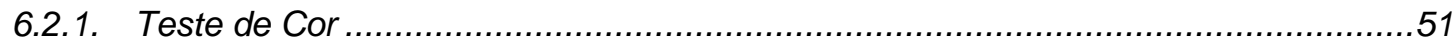

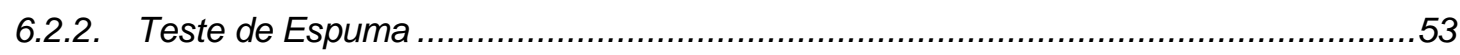

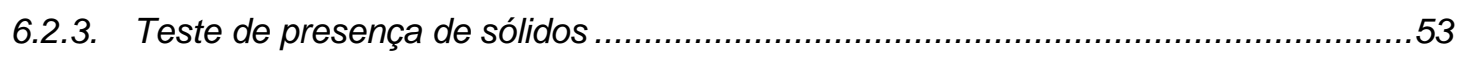

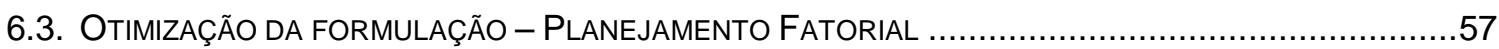

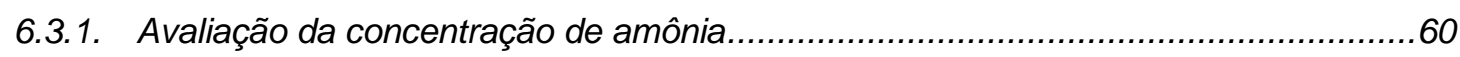




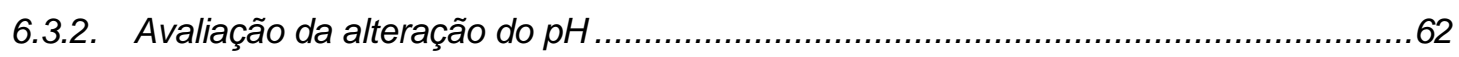

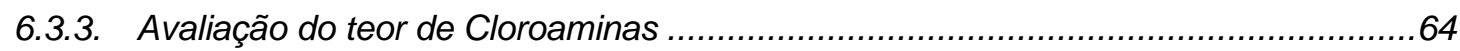

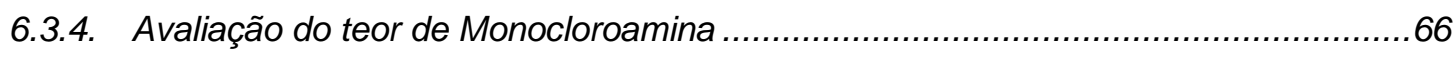

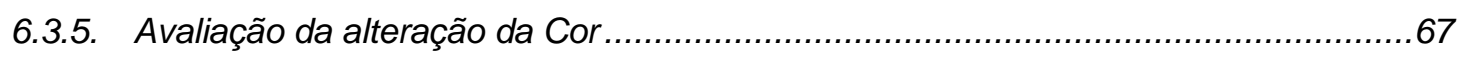

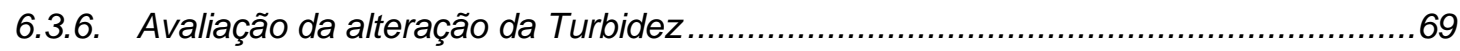

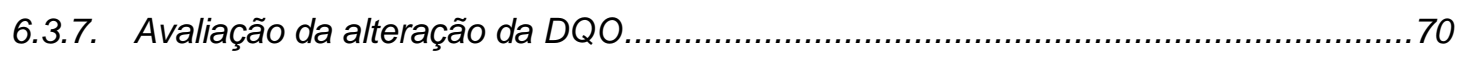

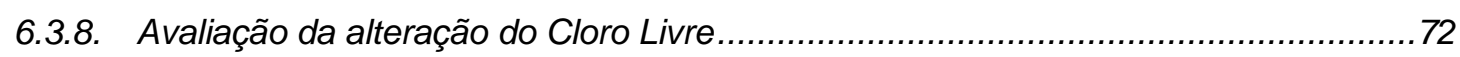

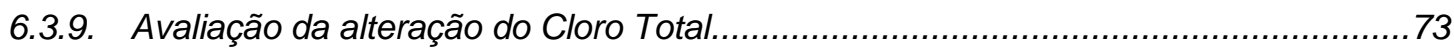

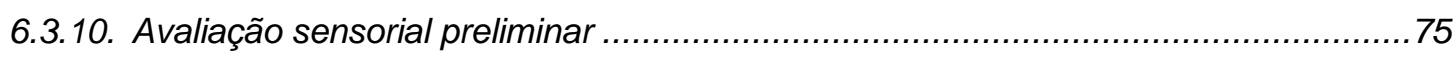

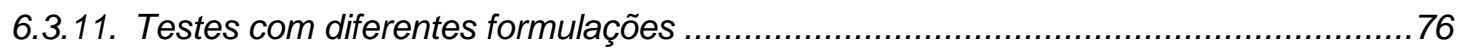

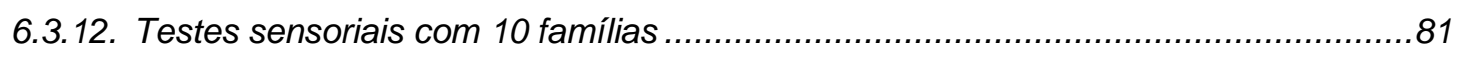

6.3.13. Testes com produtos a base de cloro disponíveis no mercado.............................83

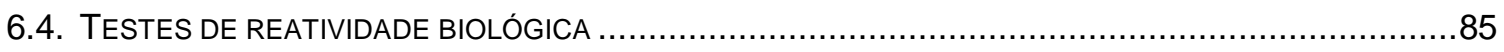

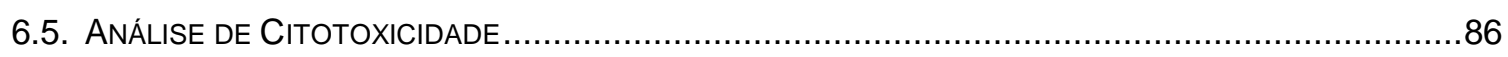

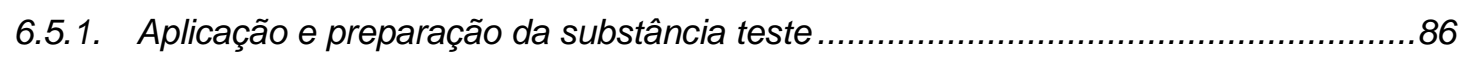

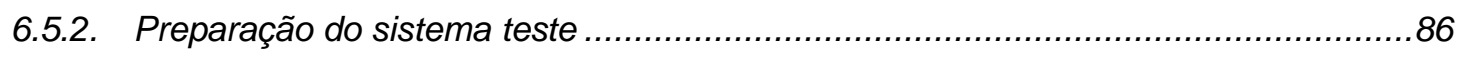

6.4.3. Resultados dos testes de Citotoxicidade............................................................96

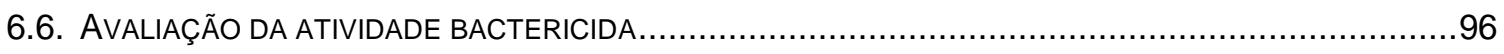

6.6.1. Aplicação e preparação da sustância teste ...........................................................96

6.6.2. Aplicação e preparação do sistema teste.............................................................96

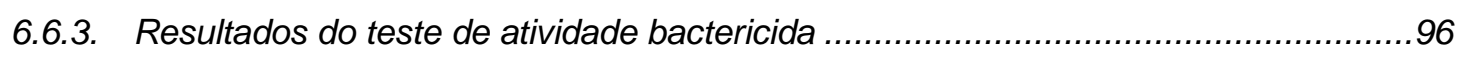

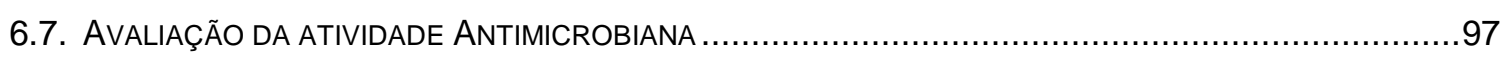

6.7.1. Aplicação e preparação das substâncias teste.....................................................97

6.7.2. Aplicação e preparação do sistema teste ...........................................................97

6.7.3. Resultados dos testes de Atividade Antimicrobiana ..............................................98

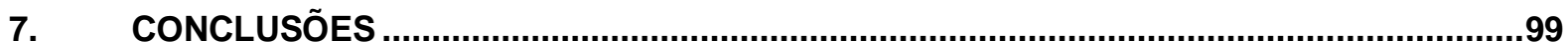

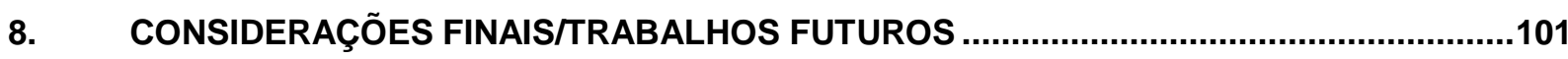

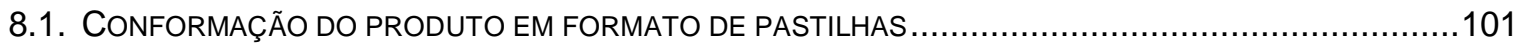

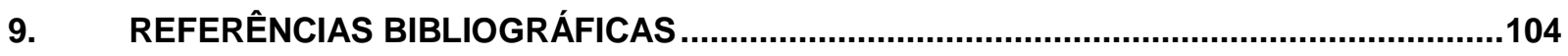

10. ANEXOS 


\section{LISTA DE TABELAS}

Tabela 1: Custo médio da tarifa social em Jundiaí..... 7

Tabela 2: Volume consumido de água em descargas residenciais, com famílias de 1 a 5 pessoas

Tabela 3: Custos de consumo com água em descargas residenciais, com famílias de 1 a 5 pessoas.

Tabela 4: Redução do volume de água com a utilização do produto, com famílias de 1 a 5 pessoas

Tabela 5: Redução dos custos com a utilização do produto, com famílias de 1 a 5 pessoas com base na Tarifa Social de Jundiaí (dados do ano de 2013)..............10

Tabela 6: Valor do pH da solução à 1\% ....................................................................... 11

Tabela 7: Estruturas químicas e teor de matéria ativa dos principais compostos

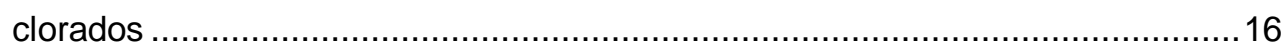

Tabela 8: Dados do faturamento de produtos alvejantes clorados .....................................18

Tabela 9: Comparação por escala numérica de 0 a 4 , entre várias qualidades dos principais derivados clorados disponíveis no mercado .....................................25

Tabela 10: Resultados das análises da solução de urina diluída .........................................50

Tabela 11: Resultados dos testes para avaliação do comportamento do NaDCC em solução de urina .51

Tabela 12: Resumo dos efeitos para o planejamento fatorial realizado..................................75

Tabela 13: Resultados das diferentes formulações avaliadas................................................77

Tabela 14: Resultados dos testes para as 6 formulações e a amostra bruta ........................77

Tabela 15: Resultados dos testes com as fórmulas FM1, FM2 e FM3 e uma adição de carga de urina em cada caso.

Tabela 16: Resultados dos testes com a formula FM1 (teste com 10 famílias) ......................82

Tabela 17: Resultados dos testes com a formula FM2 (teste com 10 famílias) .....................82

Tabela 18: Resultados dos testes com a formula FM3 (teste com 10 famílias) .....................82

Tabela 19: Resultados dos testes com os 3 produtos disponível no mercado........................ 85

Tabela 20: Formulações para análises de reatividade biológica ............................................86

Tabela 21: Valores de viabilidade celular obtidos para cada concentração dos extratos das substâncias de referência e da substância-teste

Tabela 22: Número de cilindros com resultados positivos para os micro-organismos testados 


\section{LISTA DE FIGURAS}

Figura 1: Disponibilidade de água no mundo e uso nas atividades humanas ..................... 1

Figura 2: Expressão geral do consumo de água relacionado às perdas e desperdícios .....2

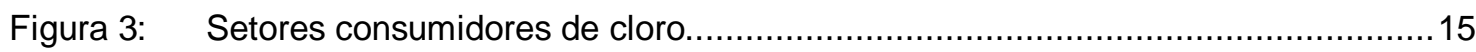

Figura 4: Gráfico das empresas produtoras de cloro a nível nacional ................................17

Figura 5: Gráfico da Produção Mundial de cloro ............................................................ 18

Figura 6: Volume de alvejantes e água sanitária consumido............................................. 19

Figura 7: Faturamento das empresas de alvejante e água sanitária....................................20

Figura 8: Dados do volume e faturamento de água sanitária .........................................20

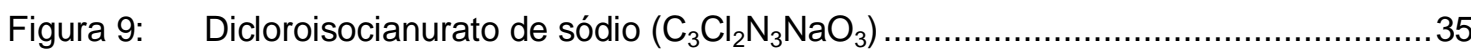

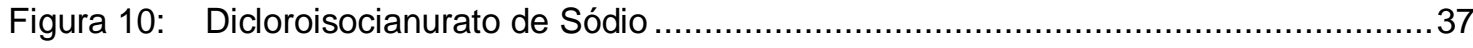

Figura 11: Efeito do $\mathrm{pH}$ na distribuição de ácido hipocloroso e íon hipoclorito na água .........38

Figura 12: Reação de hidrólise da ureia produzindo amônia................................................39

Figura 13: Curva de cloro residual mostrando um "break-point" típico. Conteúdo de

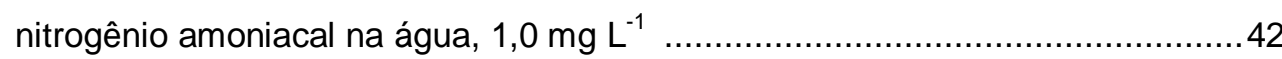

Figura 14: Dimensões das bacias sanitárias comuns......................................................... 47

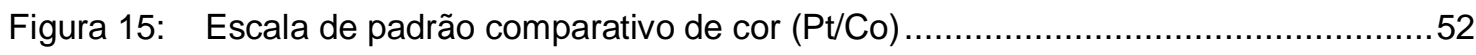

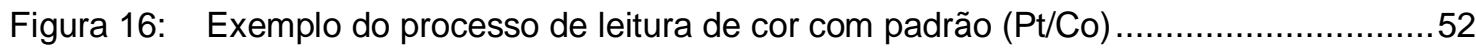

Figura 17: Exemplo do processo de medida do nível de espuma nos béqueres...................53

Figura 18: Béqueres contendo urina diluída diluída em água (proporção 1:3) antes da adição das massas de NaDCC ................................................................54

Figura 19: Sequência dos béqueres após 2 minutos da adição do produto ............................55

Figura 20: Visão superior dos béqueres após 10 minutos da adição do produto ...................56

Figura 21: Soluções de urina em tubos de ensaio após 20 minutos da adição do produto ...57

Figura 22: Sequência dos 8 testes e as massas das formulações para adição ....................59

Figura 23: Avaliação imediatamente após a adição das massas.........................................59

Figura 24: Avaliação após 5 minutos da adição das massas ..............................................60

Figura 25: Avaliação em tubos Nesler após 10 minutos da adição das massas ...................60

Figura 26: Teste para verificação da significância dos efeitos para os valores da resposta da medição da concentração de amônia..........................................................61

Figura 27: Gráfico de Rankit para concentração de amônia..................................................62

Figura 28: Teste para verificação da significância dos efeitos para os valores da resposta

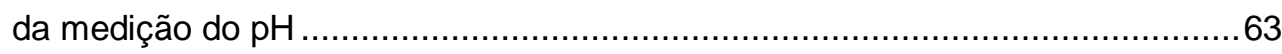

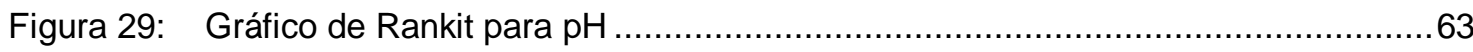


Figura 30: Teste para verificação da significância dos efeitos para os valores da resposta da medição de Cloroaminas .65

Figura 31: Gráfico de Rankit para Cloroaminas ..... .65

Figura 32: Teste de verificação da significância dos efeitos para os valores da resposta da medição de Monocloroaminas. .66

Figura 33: Gráfico de Rankit para Monocloroaminas 67

Figura 34: Teste para verificação da significância dos efeitos para os valores da resposta da medição de Cor.

Figura 35: Gráfico de Rankit para Cor 68

Figura 36: Teste para verificação da significância dos efeitos para os valores da resposta da medição da Turbidez . 69

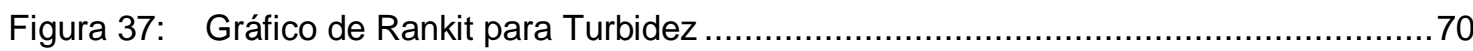

Figura 38: Teste para verificação da significância dos efeitos para os valores da resposta da medição da DQO.

Figura 39: Gráfico de Rankit para DQO

Figura 40: Teste para verificação da significância dos efeitos para os valores da resposta da medição do Cloro Livre. .72

Figura 41: Gráfico de Rankit para Cloro Livre .73

Figura 42: Teste para verificação da significância dos efeitos para os valores da resposta da medição do Cloro Total. 74

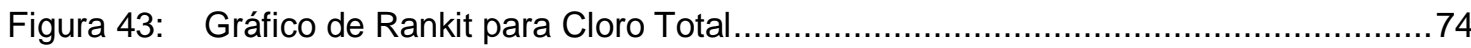

Figura 44: Resultado da avaliação sensorial preliminar ................................................. 76

Figura 45: Avaliação dos béqueres imediatamente após a adição das massas....................78

Figura 46: Avaliação dos béqueres imediatamente após 10 minutos da adição do

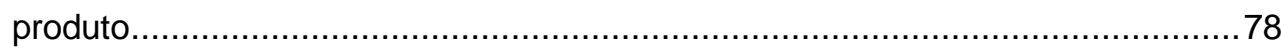

Figura 47: Avaliação dos béqueres imediatamente após 10 minutos da adição do produto. Visão superior dos Béqueres de 4 a 6 e do controle...............................79

Figura 48: Visão superior do béquer 1 com a adição de 1 carga de urina ............................79

Figura 49: Visão superior do béquer 2 com a adição de 1 carga de urina ............................. 80

Figura 50: Visão superior do béquer com a adição de 1 carga de urina .............................. 80

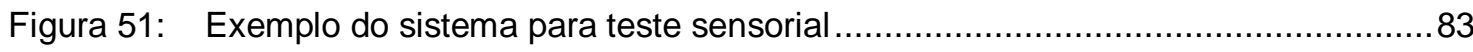

Figura 52: Produtos a base de cloro disponíveis em mercados ...................................... 84

Figura 53: Imagem dos produtos e dos béqueres contendo urina diluída.............................84

Figura 54: Porcentagem de viabilidade celular das substâncias de referência ......................87

Figura 55: Porcentagem de viabilidade celular das substâncias teste ..................................88 
Figura 56: Fotomicrografia das células $\mathrm{CHO}-\mathrm{K} 1$ expostas à substância teste $\mathrm{FM} 1$...............89

Figura 57: Fotomicrografia das células $\mathrm{CHO}-\mathrm{K} 1$ expostas à substância teste FM2 ..............91

Figura 58: Fotomicrografia das células $\mathrm{CHO}-\mathrm{K} 1$ expostas à substância de referência $284 \mathrm{CN}$.

Figura 59: Fotomicrografia das células $\mathrm{CHO}-\mathrm{K} 1$ expostas à substância de referência $284 \mathrm{CP}$ .95

Figura 60: Halo de inibição provocado pela amostra FM1 ...................................................98

Figura 61: Halo de inibição provocado pela amostra FM2 ….............................................98

Figura 62: Sistema de coleta de efluentes do vaso sanitário................................................. 101

Figura 63: Sistema de coleta de efluentes do vaso sanitário..................................................102

Figura 64: Prensa Hidráulica para compactação das pastilhas ........................................... 102

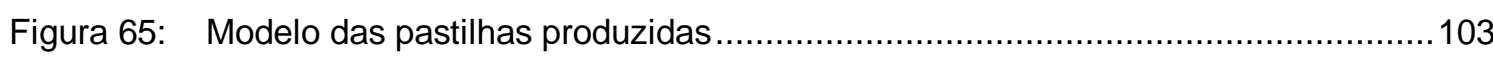




\section{LISTA DE ABREVIATURAS}

\begin{tabular}{ll} 
ABICLOR & Associação Brasileira da Indústria do Cloro \\
ABNT & Associação Brasileira de Normas Técnicas \\
ANVISA & Agência Nacional de Vigilância Sanitária \\
CAS & Chemical Abstract Service \\
CI50\% & Concentração que inibe 50\% da viabilidade celular \\
CHO-K1 & Cell Hamster Ovary \\
CONAMA & Conselho Nacional do Meio Ambiente \\
CRC & Cloro Residual Combinado \\
CRL & Cloro Residual Livre \\
DAE & Departamento de Água e Esgoto \\
DQO & Demanda Química de Oxigênio \\
EPA & Environmental Protection Agency \\
ETA & Estação de Tratamento de Água \\
EUA & Estados Unidos da América \\
FAPESP & Fundo de Amparo a Pesquisa do Estado de São Paulo \\
GPF & Galões por Função \\
HPCS & Hipoclorito de Sódio \\
IBGE & Instituto Brasileiro de Geografia e Estatística \\
INS & Insatisfatório \\
IPEN & Instituto de Pesquisas Energéticas e Nucleares \\
LPF & Litros por Função \\
NADCC & Dicloro Isocianurato de Sódio \\
NSF & National Science Foundation \\
NTU & Unidade de Turbidez Nefelométrica \\
ONU & Organização das Nações Unidas \\
PDCA & Plan-Do-Check-Act ou Plan-Do-Check-Adjust \\
PEAD & Polietileno de Alta Densidade \\
PH & Potencial Hidrogeniônico \\
RAT & Satisfatório \\
\hline Resolução da Diretoria Colegiada \\
THihalometano \\
THermissível
\end{tabular}




\section{INTRODUÇÃO}

A demanda por água está aumentando devido ao crescimento populacional, desenvolvimento tecnológico e mudanças climáticas, diminuindo a disponibilidade hídrica, o que torna esse um recurso cada vez mais escasso. Existe uma necessidade urgente de encontrar soluções inovadoras tanto para o consumo quanto para a geração e perdas de água no sistema de abastecimento e distribuição.

A disponibilidade de água no mundo e o uso de água doce por humanos são apresentados na FIG. 1.

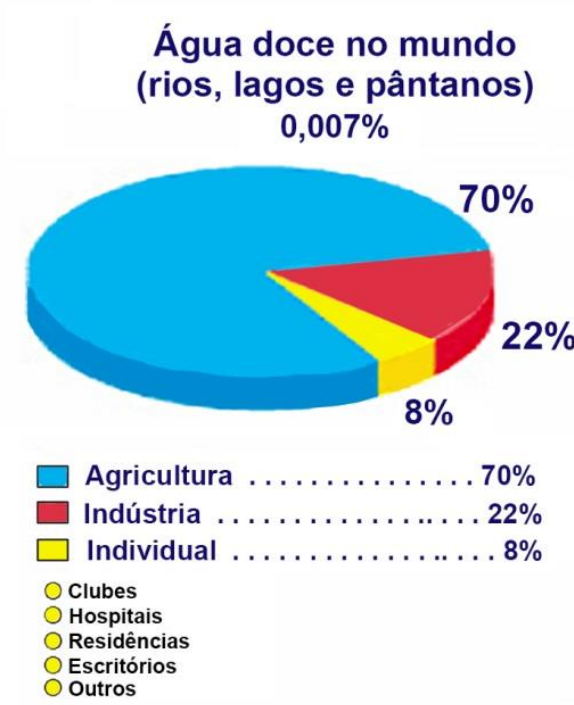

Fonte: World Resources Institute, ONU
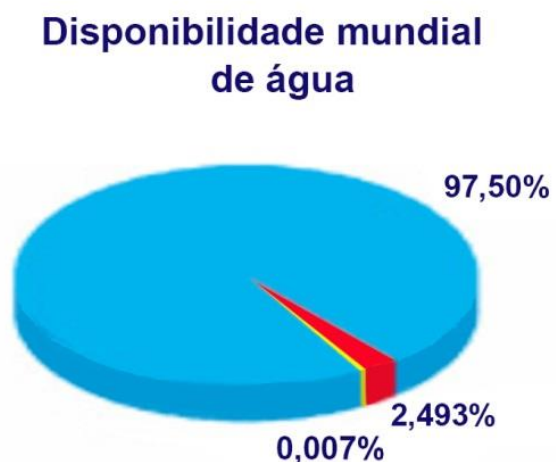

$\square$ Oceanos . . . . . . . . . 97,50\%

$\square$ Água doce (difícil acesso). . . . . 2,493\%

$\square$ Água doce (acessível). . . . . . . 0,007\%

Fonte: World Resources Institute, ONU

Figura 1: Disponibilidade de água no mundo e uso nas atividades humanas (World Resourses Institute, ONU).

A provável escassez da água é colocada na pauta de discussão mundial como um grande desafio da atualidade e que deve se agravar nas próximas décadas. No Brasil, a Política Nacional de Recursos Hídricos, instituída pela Lei 9433/97, estabelece entre seus objetivos "assegurar à atual e às futuras gerações a necessária disponibilidade de água, em padrões de qualidade adequados aos respectivos usos". Não obstante, aumentam de maneira rápida as 
regiões e os países onde o desenvolvimento econômico, o crescimento populacional e o surgimento de enormes aglomerados urbanos exercem grande pressão sobre os recursos hídricos.

A ausência de estruturas e sistemas de gestão adequados, aliados a padrões culturais incompatíveis, deixam milhões de pessoas sem o adequado acesso à água e intensificam os conflitos de uso, além de promoverem a degradação do recurso.

O termo "desperdício" compreende basicamente as perdas evitáveis, ou seja, correspondem claramente à negligência do usuário que não tem consciência ambiental. Isso pode estar vinculado ao uso propriamente dito ou ao funcionamento geral dos sistemas. Em geral, o desperdício de água está associado ao comportamento de uso e por isso é mais evidente nos sistemas individuais (edificações). As parcelas de perdas e desperdícios representam custos para os usuários e para a sociedade, sem aportar benefícios. Portanto sua eliminação ou redução a níveis razoáveis resulta em consideráveis benefícios ambientais e econômicos. Considerada essa classificação, a quantidade de água consumida pode ser expressa pela relação entre as destinações conforme apresentado na FIG. 2.

\section{CONSUMO TOTAL = CONSUMO EFETIVO + PERDA + DESPERDÍCIO}

Figura 2: Expressão geral do consumo de água relacionado às perdas e desperdícios.

Em geral o desperdício está associado ao comportamento humano de pessoas, empresas ou órgãos públicos que não têm consciência sobre o valor da água, mas pode também se enquadrar no campo da negligência comportamental consciente que não sofre ou que se sobrepõe a pressões contrárias.

Exemplo típico do desperdício é a quantidade de água não utilizada quando uma torneira permanece aberta a despeito de a água não estar sendo utilizada. Tal fato pode ser observado no cotidiano na lavagem de um veículo, 
quando o usuário simplesmente abandona a mangueira com água escoando enquanto ensaboa o carro. Comportamentos específicos também levam ao desperdício, como o hábito de abrir o registro do chuveiro elétrico antes de tirar a roupa para o banho (Prosab, 2009).

Nesse cenário, assumem especial importância as ações objetivando a ampliação da cobertura dos serviços de abastecimento água e de esgotamento sanitário, dentre os quais se inserem os programas voltados para o incremento da eficiência no uso da água. Em 2006, cerca de 1,1 bilhão de pessoas não tinham acesso à água potável e 2,6 bilhões careciam de soluções racionais para disposição de excretas no mundo (UNDP, 2006).

No Brasil, em 2006, o índice de cobertura com abastecimento de água era de $93,1 \%$ e o de esgotamento sanitário de $48,3 \%$, dos quais, 32,2\% com tratamento (Brasil, 2007). Entre os objetivos do milênio, a Organização das Nações Unidas (ONU, 2005) incluiu como meta a redução, até 2015, dos índices de falta de cobertura à metade dos que eram observados em 2000. No Brasil, o Plano Plurianual do Governo Federal estabeleceu a meta de universalização dos serviços de saneamento no ano de 2015.

Os sistemas prediais de água e de energia podem se referir a edificações dos setores residencial, comercial ou público. Edificações com ocupação predominante de escritórios, tais como prédios comerciais e públicos, apresentam comportamento de água e de energia elétrica similares, o que não ocorre com relação aos edifícios residenciais.

O consumo de água residencial pode constituir mais da metade do consumo total de água nas áreas urbanas (Gonçalves, 2006). Na região metropolitana de São Paulo, o consumo de água residencial corresponde a 84,4\% do consumo total urbano (incluindo também o consumo em pequenas indústrias). $\mathrm{Na}$ cidade de Vitória, a porcentagem desse consumo é bem similar, correspondendo a aproximadamente $85 \%$ desse total (Rodrigues, 2005).

O consumo de água residencial inclui tanto o uso interno quanto o uso externo às residências. As atividades de limpeza e higiene são as principais 
responsáveis pelo uso interno, enquanto o externo deve-se à irrigação de jardins, lavagem de áreas externas, lavagem de veículos e piscinas, entre outros. Estudos realizados no Brasil e no exterior mostram que dentro de uma residência o maior consumo de água concentra-se na descarga dos vasos sanitários, na lavagem de roupas e nos banhos. Em média, $40 \%$ do total de água consumida em uma residência são destinados aos usos não potáveis.

No ambiente doméstico, o uso da água com fins higiênicos e sanitários, descarga após a micção, como exemplo específico, é uma das situações de consumo expressivo e que ainda pode ser otimizada ou racionalizada. Alguns países como Estados Unidos, México, Canadá e Austrália têm incentivado a população a substituir as bacias sanitárias antigas e válvulas de fluxo embutidas na parede por descarga ecológica do tipo caixa acoplada.

O uso racional da água nos diversos segmentos da sociedade, em especial, nos grandes centros urbanos, é uma das melhores alternativas para aplicação imediata e cujo impacto pode ser sentido como uma menor pressão sobre a geração. Se bem organizado e conduzido, esses programas de conscientização da população e das atividades produtivas que mais demandam água podem resultar em economia significativa e com menores investimentos de capital, dando fôlego para uma ação mais consistente do poder público e dos detentores do capital.

Válvula de parede e outros equipamentos antigos são grandes consumidores de água. Essas válvulas podem consumir um volume médio de $15 \mathrm{~L}$ de água por função, Ipf, já os modelos mais modernos consomem em média $6 L$ de água, conforme determina a Norma ABNT NBR 15099:2004 (ABNT, 2004). O termo bacia sanitária é definido pela Norma ABNT NBR 8160:1999 (ABNT, 1999).

Estudos demonstram que 35\% da água de uma residência esvaem-se pela bacia em descargas sanitárias. Avalia-se que no Brasil seria preciso trocar 100 milhões de bacias sanitárias, que gastam em média 15 a 30 litros de água a cada descarga, sendo que o mercado já oferece, há anos, produtos que fazem a higienização de latrinas com 6 a 9 litros (Okamura, 2006). 
A substituição de bacias sanitárias antigas por novas fica em torno de $\mathrm{R} \$ 350,00$ por unidade em média. Essa troca, que comprovadamente promove uma economia entre 50 a $55 \%$ de água, não é motivadora para o consumidor brasileiro. Estima-se que no Brasil é necessária a troca de 100 milhões de bacias sanitárias por modelos mais econômicos. (Okamura, 2006).

Um programa de substituição de bacias sanitárias na cidade de Nova lorque, EUA, o "Toilet Rebate Program", obteve uma economia de 60 milhões de galões de água por dia. A população dessa cidade aciona aproximadamente 10.000 descargas por segundo. Os equipamentos antigos utilizam 5 galões de água por função, gpf, que equivale a aproximadamente 3,8 L/galão $\times 5$ galões = $19 \mathrm{~L}$ de água. Com um programa de "recompensa" ou incentivo em dinheiro, os nova-iorquinos começaram a substituir esses antigos equipamentos por novos que consomem no máximo 1,6 galões ou $6 \mathrm{~L}$ de água.

Além dos Estados Unidos, o México também dá exemplo de programa semelhante, iniciado em 1985. Em 1986, foram regulamentadas as condições de funcionamento das bacias de 6 litros, com prazo de 9 meses para que a indústria de produtos sanitários se adaptasse às novas exigências da norma, e para que todos os novos lançamentos de produtos (bacias), a partir desta data, fossem adequados a essa norma. Em 1991, o governo proibiu a venda e a comercialização de toda bacia com funcionamento acima de 6 litros e estabeleceu para todos os modelos de bacias um incentivo, chamado de "reposition cost", desconto obtido pelos proprietários de casas, apartamentos, escritórios, lojas, fábricas na reposição de suas bacias, quando a bacia antiga era devolvida nas revendas (Okamura, 2006).

Somente nos últimos anos a preocupação com o uso racional da água tem ganhado força entre os consumidores, e não por acaso. Com um cenário futuro tanto de escassez como de alta nos preços da água, o melhor a fazer é mudar hábitos hoje para reduzir o impacto amanhã. Entretanto, a mudança de hábitos, mais do que razões financeiras e culturais, pode ser o principal entrave para a redução do consumo de água. Se a ação não for coletiva ou, pelo menos, 
de uma fração significativa dos consumidores, o uso da água continuará sob grande influência da geração e não somente da demanda.

Nos condomínios da cidade de São Paulo os custos de água ficam em segundo lugar, só perdendo para os custos de energia. Consequentemente, qualquer iniciativa de economizar água terá um efeito muito positivo no orçamento do condomínio. O volume de água descartado nos sistemas com válvulas de fluxo embutidas pode chegar a oito vezes mais quando comparado ao sistema mais econômico para alcançar o mesmo objetivo. Ações em comunidades pequenas e relativamente homogêneas podem se tornar um início bem consistente em programas de redução do consumo de água.

\subsection{Justificativa da escolha}

A urina humana é composta principalmente de água com uma média de $96 \%$, em volume. Em sua composição também estão presentes: uréia, ácido úrico, sais e outras substâncias principalmente dos processos metabólicos do organismo. Parte de suas características físico-químicas como volume, $\mathrm{pH}$ e a concentração de sais são regulados tanto por hábitos pessoais como pelos hormônios atuantes nos rins que garantem eliminação da água e dos sais e assim, manter o equilíbrio ácido-base e mineral do corpo (Zancheta, 2007).

$\mathrm{O}$ volume de urina eliminada por pessoas normais varia entre 1 e $2 \mathrm{~L}$ por dia e depende tanto dos hábitos alimentares como do equilíbrio hormonal. Com uma dieta normal em pessoa saudável o $\mathrm{pH}$ da urina pode variar entre 4,8 a 8,0 e deve se estabilizar em torno de 6,0 em amostra de 24 horas.

Em condições normais, a urina recente apresenta-se cristalina e translúcida. Com o passar do tempo ocorre hidrólise da ureia com consequente formação de amônia (fermentação amoniacal). O aumento na concentração de íons amônio promove a elevação do $\mathrm{pH}$. Valores elevados de $\mathrm{pH}$ provocam a precipitação de fosfatos, que são relativamente insolúveis em meio alcalino. A urina alcalina, então, pode-se apresentar turva, o que às vezes provoca uma sensação estética desagradável (Bueno, 2005). 
A urina eliminada por pessoas saudáveis tem odor bastante característico, ou seja, é facilmente reconhecível, sendo a causa ainda não bem determinada. Cogita-se que possa ser causado pela presença de pequenas quantidades de alguns ácidos orgânicos voláteis. Com o passar do tempo, em repouso, a urina passa a apresentar forte odor amoniacal resultado da hidrólise bacteriana da ureia que gera amônia (Zancheta, 2007).

Como estudo de caso prospectivo, avaliaram-se informalmente os hábitos e costumes de alguns cidadãos da cidade de Jundiaí, SP. Observou-se que em uma família média de cinco pessoas, onde cada adulto expele cerca de $2 \mathrm{~L}$ de urina por dia (4 vezes em média) e que cada descarga, baseando-se nos modelos econômicos de bacias sanitárias, consome $6 \mathrm{~L}$ de água, cada pessoa utiliza, em média, $24 \mathrm{~L}$ de água por dia.

Então, uma família de cinco pessoas irá utilizar $120 \mathrm{~L}$ de água por dia, 3.600 L por mês, 43.200 L por ano, somente com descargas de urina. De acordo com as taxas de cobrança da empresa responsável pelo serviço de água e esgoto de Jundiaí, SP, em 2013, o custo da tarifa social é apresentado na TAB. 1.

Tabela 1: Custo médio da tarifa social em Jundiaí.

\begin{tabular}{c|c}
\hline Tipo de ocupação & $R \$ / m^{3}$ \\
\hline Residencial & 2,39 \\
Comercial & 4,18 \\
Industrial & 8,44 \\
\hline
\end{tabular}

Fonte: DAE, 2012.

Os valores acima levam em conta, além do consumo, o tratamento, coleta e afastamento do esgoto e estão descritos no decreto municipal 24.162 de 2012 (DAE, 2012).

A TAB. 2 ilustra o consumo de água (em litros) com famílias de 1 a 5 pessoas, cuja frequência de descargas por pessoa é de 4 vezes ao dia com uso de $6 \mathrm{~L}$ por função. Cabe lembrar que os cálculos já consideram o uso de 
sanitários de $6 \mathrm{lpf}$, ou seja, o modelo econômico comercializado. Consumos decorrentes de eventos adversos como enfermidades e relacionados à limpeza rotineira não foram considerados nos cálculos por serem dados de difícil coleta.

Tabela 2: Volume consumido de água em descargas residenciais, com famílias de 1 a 5 pessoas.

\begin{tabular}{|c|c|c|c|}
\hline & \multicolumn{3}{|c|}{ Consumo de água } \\
\hline Frequência de descargas & 4 & & \\
\hline Volume, Ipf & 6 & & \\
\hline Pessoas & L/dia & L/mês & L/ano \\
\hline 5 & 120 & 3.600 & 43.200 \\
\hline 4 & 96 & 2.880 & 34.560 \\
\hline 3 & 72 & 2.160 & 25.920 \\
\hline 2 & 48 & 1.440 & 17.280 \\
\hline 1 & 24 & 720 & 8.640 \\
\hline
\end{tabular}

Fonte: DAE, 2012.

Dados do Instituto Brasileiro de Geografia e Estatística, IBGE, indicam que a família brasileira era composta de 3,1 pessoas em 2009.

A redução de uma descarga (função) por pessoa por dia numa família com 3 pessoas (IBGE, 2010), resultaria numa economia de cerca de $24 \mathrm{~L}$ por dia ou $8.640 \mathrm{~L}$ de água por ano. O impacto seria muito significativo para uma família, estimulante quando se projeta para a população brasileira e estratégico para o planejamento público. Em termos relativos, significa uma redução de $25 \%$ no consumo de água utilizada para descargas sanitárias.

Na TAB. 3 são apresentados os custos em reais $(R \$)$, para famílias de 1 a 5 pessoas, cuja frequência de descargas por pessoa é de 4 vezes ao dia e o consumo de água por acionamento é de $6 \mathrm{~L}$ (dados do ano de 2013). 
Tabela 3: Custos de consumo com água em descargas residenciais, com famílias de 1 a 5 pessoas.

\begin{tabular}{|c|c|c|c|}
\hline \multirow{2}{*}{$\begin{array}{l}\text { Custo por } m^{3} R \$ 2,39 \\
\text { Frequência de descargas }\end{array}$} & \multicolumn{3}{|c|}{ Tarifa Social } \\
\hline & 4 & & \\
\hline Volume, Ipf & 6 & & \\
\hline Pessoas & $\mathbf{R} \$ /$ dia & R\$/mês & $\mathbf{R} \$ /$ ano \\
\hline 5 & $\mathrm{R} \$ 0,287$ & $\mathrm{R} \$ 8,61$ & $\mathrm{R} \$ 103,32$ \\
\hline 4 & $\mathrm{R} \$ 0,229$ & $\mathrm{R} \$ 6,87$ & $\mathrm{R} \$ 82,44$ \\
\hline 3 & $R \$ 0,172$ & $\mathrm{R} \$ 5,16$ & $\mathbf{R} \$ 61,92$ \\
\hline 2 & $\mathrm{R} \$ 0,115$ & $\mathrm{R} \$ 3,45$ & $\mathrm{R} \$ 41,40$ \\
\hline 1 & $\mathrm{R} \$ 0,057$ & $\mathrm{R} \$ 1,71$ & $\mathrm{R} \$ 20,52$ \\
\hline
\end{tabular}

Fonte: DAE, 2012.

Baseado nesses números, o gasto de uma família de cinco pessoas representa $R \$ 103,32$ por ano somente com descargas para eliminação de urinas.

Pela proposta, utilizando o sistema de tratamento, haveria a redução do consumo de água das famílias conforme demonstrado na TAB. 4, e uma consequente queda no custo pela utilização da água, TAB. 5.

Tabela 4: Redução do volume de água com a utilização do produto, com famílias de 1 a 5 pessoas.

\begin{tabular}{cccc}
\hline & \multicolumn{3}{c}{ Volumes com tratamento de urina } \\
\hline $\begin{array}{c}\text { Frequência de descargas } \\
\text { Volume, Ipf }\end{array}$ & $\mathbf{1}$ & & \\
\hline Pessoas & $\mathbf{6}$ & $\mathbf{R} \mathbf{\text { /mês }}$ & $\mathbf{R} \mathbf{\text { ano }}$ \\
\hline $\mathbf{5}$ & 30 & 900 & 10.800 \\
$\mathbf{4}$ & 24 & 720 & 8.640 \\
$\mathbf{3}$ & 18 & 540 & 6.480 \\
$\mathbf{2}$ & 12 & 360 & 4.320 \\
$\mathbf{1}$ & 6 & 180 & 2.160 \\
\hline
\end{tabular}

Fonte: DAE, 2012. 
Tabela 5: Redução dos custos com a utilização do produto, com famílias de 1 a 5 pessoas com base na Tarifa Social de Jundiaí (dados do ano de 2013).

\begin{tabular}{cccc}
\hline Custo por $\boldsymbol{m}^{\mathbf{3}} \mathbf{R} \mathbf{\text { 2,39 }}$ & \multicolumn{3}{c}{ Com tratamento da urina } \\
\hline $\begin{array}{c}\text { Frequência de descargas } \\
\text { Volume, Ipf }\end{array}$ & $\mathbf{1}$ & $\mathrm{L} / \mathrm{mês}$ & \\
\hline Pessoas & $\mathrm{L} /$ dia & $\mathrm{R} \$ 2,16$ & $\mathrm{R} \$ 25,92$ \\
\hline $\mathbf{5}$ & $\mathrm{R} \$ 0,072$ & $\mathrm{R} \$ 1,71$ & $\mathrm{R} \$ 20,52$ \\
$\mathbf{4}$ & $\mathrm{R} \$ 0,057$ & $\mathrm{R} \$ 1,29$ & $\mathrm{R} \$ 15,48$ \\
$\mathbf{3}$ & $\mathrm{R} \$ 0,043$ & $\mathrm{R} \$ 0,87$ & $\mathrm{R} \$ 10,44$ \\
$\mathbf{1}$ & $\mathrm{R} \$ 0,029$ & $\mathrm{R} \$ 0,42$ & $\mathrm{R} \$ 5,04$ \\
\hline
\end{tabular}

Fonte: DAE, 2012.

Segundo dados do IBGE (2010), a população brasileira em 2009 já havia ultrapassado os 191 milhões de habitantes, sendo cada família composta em média por 3,1 pessoas.

O uso do NaDCC como agente sanitizante torna-se interessante, pois a sua eficácia na redução da população microbiana é conhecida e apresentada na literatura (Nascimento e Silva, 2010; Nascimento Filho, 2005; Silva et al., 2003).

Este trabalho propõe o uso do dicloroisocianurato de sódio, NaDCC, número CAS 51580-86-0, como principal agente sanitizante químico. O NaDCC já é utilizado para tratamento de águas de piscinas, é utilizado em estações de tratamento de água para desinfecção secundária e é aprovado pela Agência Nacional de Vigilância Sanitária, ANVISA, para tratamento de água para consumo humano (Anvisa, 2003). A ação sanitizante do produto é obtida pela geração de gás cloro. Equações químicas são apresentadas ao longo do trabalho.

Um aspecto muito importante que contribui para o aumento do uso de derivados clorados, de origem orgânica, é sua característica de reduzir a probabilidade de formação de Trihalomentanos (THMs), subprodutos do processo de desinfecção, que é muito pequena ou nula, ou seja, os níveis formados não são significativos, se comparados com os derivados clorados de origem inorgânica (Macêdo, 1997). Deve-se ressaltar que, derivados clorados de origem orgânica, como o dicloroisocianurato de sódio e o ácido tricloroisocianúrico foram "Certificados" para serem utilizados em tratamento químico de água para 
abastecimento público pelo NSF (National Sanitation Foundation), dos Estados Unidos, em 2002 e o ácido tricloroisocianúrico em julho de 2001 recebeu o registro na EPA (Environmental Protection Agency) para desinfecção de água potável (Nsf 2002; Oxychem, 2001).

Outra característica que é considerada como vantagem pelo dicloroisocianurato de sódio para seu uso no dia a dia é o pH da sua solução a $1 \%$, que varia de 6,0 a 8,0 enquanto $\mathrm{pH}$ do hipoclorito de sódio e/ou de cálcio varia de 11,0 a 12,5; que é cáustico. A TAB. 6 apresenta os valores do pH para os principais derivados clorados.

Tabela 6: Valor do pH da solução a 1\%

\begin{tabular}{lc}
\hline \multicolumn{1}{c}{ Derivado clorado } & pH da solução a 1\% \\
\hline Hipoclorito de sódio & $11,5-12,5$ \\
Hipoclorito de cálcio & $10,5-11,5$ \\
Dicloro isocianuro de sódio & $6-8$ \\
Ácido tricloro isocianúrico & $2,7-2,9$ \\
\hline
\end{tabular}

Fonte: (Hidroall, 2000a; (Hidroall, 2000b); (HTH, 1999); (Genco, 1998); (Dychdaka, 1991); (Oxychem, 2001). 


\section{OBJETIVOS E METAS}

\subsection{Objetivo geral}

Propor tratamento químico da urina diretamente em bacia sanitária, visando à redução do consumo de água em descargas sanitárias.

\subsubsection{Objetivos Específicos}

- Desenvolver um método de tratamento da urina em bacia sanitária;

- Avaliar a eficiência do tratamento da urina resultando na redução do consumo de água devido à redução de descargas;

- Analisar a eliminação ou minimização de aspectos repulsivos como cor e odor e também de microrganismos que se desenvolvem nas águas da bacia sanitária após a micção.

\subsection{Metas}

- Pretende-se com este projeto obter um método para tratamento da urina em bacias sanitárias, reduzindo o consumo de água no processo de descarga em banheiros com a consequente diminuição de custos de consumo;

- Desenvolver e propor o uso de um produto cuja composição deverá atender o objetivo deste projeto;

- Propor a redução da quantidade de água atualmente utilizada em descargas em bacia sanitária devido à conscientização e mudança de hábitos sociais. 


\section{APORTE FINANCEIRO}

3.1. Projeto FAPESP: Estudo da Redução de Consumo de água em Descargas Residenciais. Projeto PIPE-FAPESP- Processo 10/502244.

A viabilidade do projeto está suportada pela avaliação de um projeto submetido à FAPESP sob a coordenação do aluno de mestrado Antonio César Teixeira de Toledo, autor da presente dissertação. Em 21 de Dezembro de 2012 a proposta foi aprovada e foram sugeridas alterações no cronograma de desembolso do recurso uma vez que a proposta inicial foi apresentada em 2010 e necessitava de algumas atualizações. Desta forma a assinatura do Termo de Outorga foi realizada em 23 de Abril de 2013. 


\section{REVISÃO DA LITERATURA}

\subsection{Consumo e produção de produtos a base de Cloro}

O elemento cloro somente foi elucidado em 1810 pelo químico inglês Humphry Davy, pois até então se acreditava que o mesmo não era um elemento e sim uma substância (Fernandes, 2009).

O processo produtivo desse elemento se espelha em três processos de eletrólise o de mercúrio, o de diafragma e o de membrana. Cada processo desses apresenta uma peculiaridade envolvida no seu desenvolvimento (Fernandes, 2009; Brient, 2005).

Desses processos o mais utilizado no mundo, representando $46 \%$ é do diafragma, seguido do de membrana $32 \%$ e do de mercúrio com a representação de $22 \%$ (Andrade, 2006).

A produção de cloro a nível nacional é representada por três grandes empresas: Braskem, Dow e Carbocloro. Mundialmente quem lidera a produção de cloro é a empresa Norte-Americana Dow, com cerca de 6,3 milhões de t/a (Fernandes, 2009; Brient, 2005; Andrade, 2006).

As aplicações do cloro são muito variadas o que the dá o título de reagente mais empregado na indústria química: participa na produção de $60 \%$ de todos os produtos químicos de importância comercial e de $85 \%$ dos produtos farmacêuticos.

A indústria do cloro-soda é considerada uma das mais importantes atividades do mundo, tendo como consumidores os setores: papel e celulose, química e petroquímica, alumínio, construção civil, sabões e detergentes, têxtil, metalúrgicas, tratamento de água entre outros (Fernandes, 2009). A FIG. 3 ilustra a distribuição do consumo da produção de nacional de cloro em 2011. 


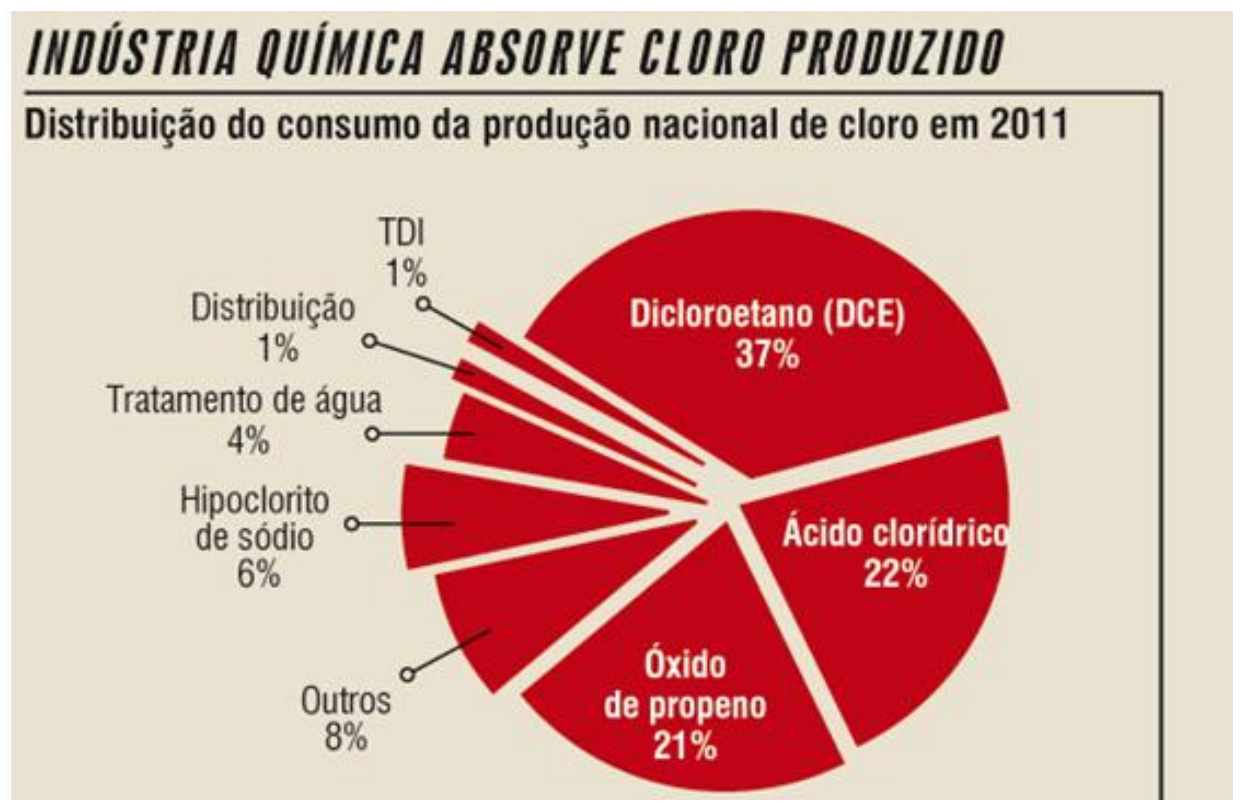

Figura 3: Setores consumidores de cloro (Abiclor, 2011).

Conforme citado anteriormente os compostos derivados do cloro podem ser aplicados em vários setores e devido a isso é considerado um dos sanitizantes mais usados pela indústria de alimentos, por causa da facilidade de uso, baixo custo, atividade microbiana reconhecida e completa dissolução em água.

Apesar dos compostos de cloro terem utilidade reconhecida em vários processos, em alguns setores, principalmente na purificação da água e o setor de limpeza, esses compostos têm chamado a atenção de alguns especialistas, devido à formação de trihalometanos (THMs), classe de compostos reconhecidamente carcinogênicos.

Em decorrência desse problema tem-se buscado alternativas de compostos menos agressivos como dicloroisocianurato de sódio (NaDCC) que se mostra um composto eficiente na sanitização e economicamente viável que gera em seu processo de desinfecção um quantidade quase nula de trialometanos.

A TAB. 7 apresenta as estruturas químicas e o teor de matéria ativa dos principais compostos clorados disponíveis no mercado. 
Tabela 7: Estruturas químicas e teor de matéria ativa dos principais compostos clorados

\begin{tabular}{lc}
\hline \multicolumn{1}{c}{ Derivados clorados inorgânicos } & Fórmulas \\
\hline Hipoclorito de sódio (12\%) & $\mathrm{CaClO}$ \\
\hline Hipoclorito de cálcio (65\%) & $\mathrm{ClO})_{2}$ \\
\hline Gás cloro (100\%) & $\mathrm{Cl}_{2}$ \\
\hline Dióxido de cloro & $\mathrm{ClO}_{2}$ \\
\hline Derivados clorados orgânicos & Fórmulas \\
\hline Ácido tricloro isocianúrico $(90 \%)$ &
\end{tabular}

Fonte: Adaptado DYCHDALA, 1977.

Em relação à $T A B$. 7, o teor de matéria ativa é um valor aproximado. Disponíveis nas formas de sais de sódio e potássio.

\subsection{A indústria do Cloro no mercado nacional e mundial}

\subsubsection{Mercado Nacional}

Quando se refere a uma indústria de produção de cloro, correlacionase automaticamente a essa a produção de soda cáustica, visto que no decorrer do processo de produção do cloro a soda cáustica também é produzida na proporção de 1 cloro/ 1,1 soda, com isso tem-se a designação de indústria cloro/soda (Fernandes, 2006; Andrade, 2006).

Atualmente o Brasil possui 12 plantas produtoras de cloro/soda, FIG. 4, com capacidade de produzir 1280 mil toneladas de cloro, ocupando o sexto lugar na produção mundial do mesmo (Fernandes, 2006; Andrade, 2006). 


\section{Participação das Principais Empresas na Produção de Cloro} e Soda no Brasil em 2007

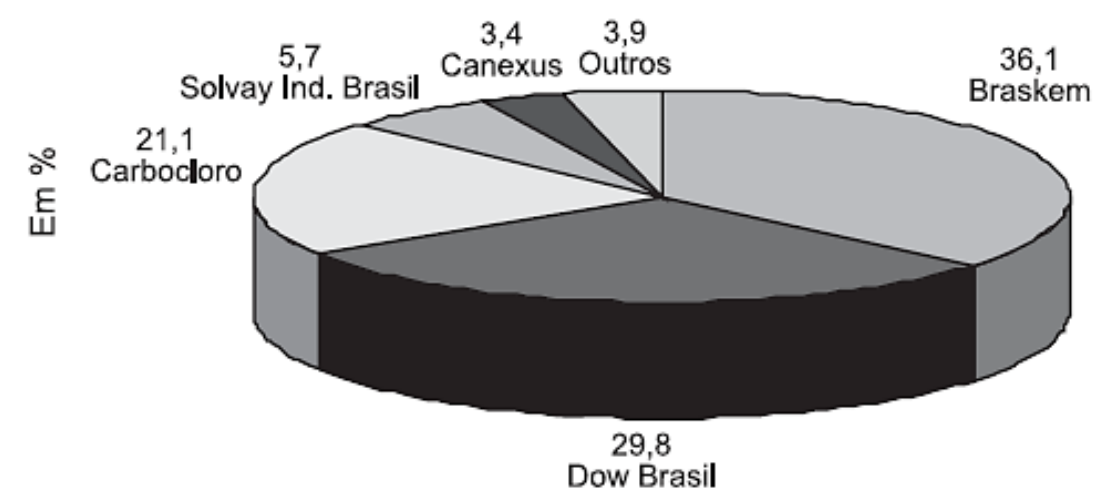

Figura 4: Gráfico das empresas produtoras de cloro a nível nacional (Fernandes, 2006; Andrade, 2006).

\subsubsection{Mercado Mundial}

A empresa norte-americana Dow lidera a produção mundial de cloro, com cerca de 6,3 milhões de t/a, sendo responsável por $13 \%$ da capacidade mundial (Fernandes, 2006; Andrade, 2006).

Já a segunda maior produtora é a Occidental Chemical Corporation (Oxychem), situada no Texas. A empresa Olin Corporation é a terceira maior produtora no mercado norte-americano e a quinta maior do mundo (Fernandes, 2006; Andrade, 2006).

Na FIG. 5 pode-se observar o panorama da produção mundial de cloro em 2007, onde a Ásia e a América do Norte eram responsáveis pela maior porcentagem na obtenção deste produto. 


\section{Distribuição da Produção Mundial de Cloro em 2007}

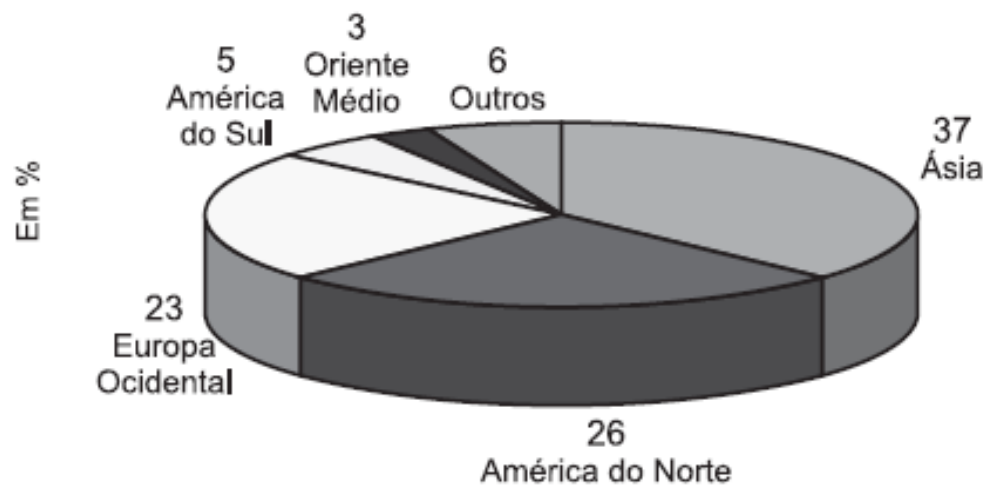

Figura 5: Gráfico da Produção Mundial de cloro (Fernandes, 2006; Andrade, 2006).

\subsection{Crescimento em volume e faturamento de produtos para limpeza a base de Cloro}

No ano 2004 no Brasil os produtos clorados ainda detinham a maior fatia do mercado de alvejantes (incluindo itens de pré-lavagem), que movimenta aproximadamente $R \$ 530$ milhões, sendo que $R \$ 458$ milhões representa o faturamento de produtos alvejantes clorados. A TAB. 8 apresenta dados da ACNielsen sobre faturamento anual (ACNielsen, 2013).

Tabela 8: Dados do faturamento de produtos alvejantes clorados.

\begin{tabular}{c|l|l}
\hline \multirow{2}{*}{$\begin{array}{c}\text { Mercado total } \\
\mathbf{R} \$ 530 \text { milhões }\end{array}$} & Alvejantes com cloro & $\mathbf{R} \$ 458$ milhões \\
\cline { 2 - 3 } & Alvejantes sem cloro & $\mathbf{R} \$ 45$ milhões \\
\cline { 2 - 3 } & Produtos para pré-lavagem & $\mathbf{R} \$ 27$ milhões \\
\hline
\end{tabular}

Nas FIG. 6 e 7 observam-se os resultados de um estudo levantado pela empresa Nielsen em 2010 considerando uma população de 163,6 milhões de pessoas em sete regiões diferentes do Brasil que fez um levantamento do volume e faturamento das categorias de produtos de limpeza.

As categorias que mais cresceram em volume em 2010 foram: concentrado de limpeza com 22,3\%, limpadores para banheiro com 21,5\%, purificadores de ar com 15,8\% de crescimento em relação ao ano de 2009 , 
confirmando o crescimento do faturamento e volume nos últimos anos de produtos de limpeza incluindo os alvejantes e água sanitária (Abipla, 2013).

Considerando o acumulado dos últimos cinco anos, as categorias que mais cresceram em volume foram: purificadores de ar $(6,34 \%)$, concentrados de limpeza $(45,3 \%)$, limpador para banheiro $(38,2 \%)$, água sanitária/ alvejante (25,5\%) (Abipla, 2013).

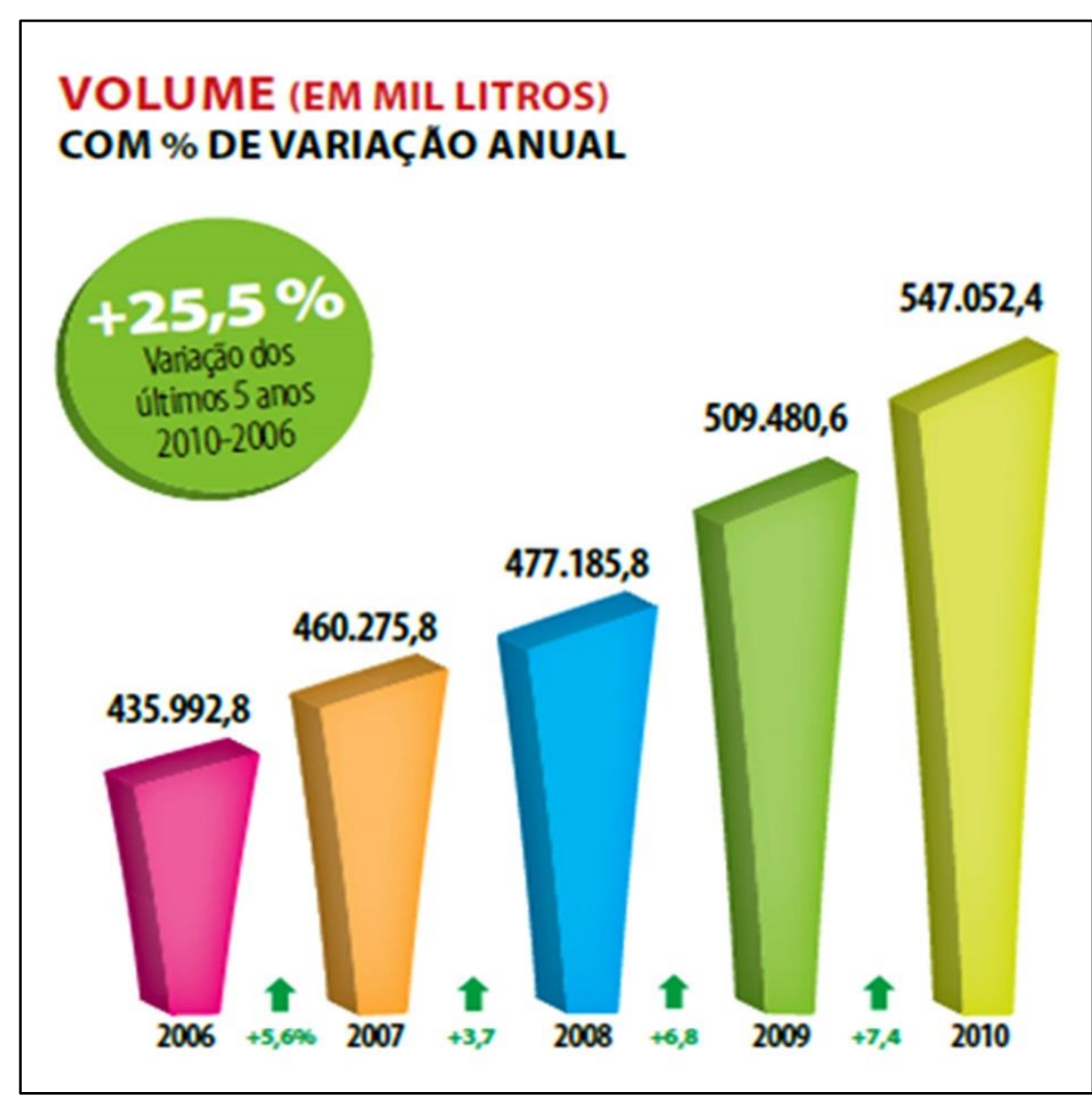

Figura 6: Volume de alvejantes e água sanitária consumido (Abipla, 2013). 


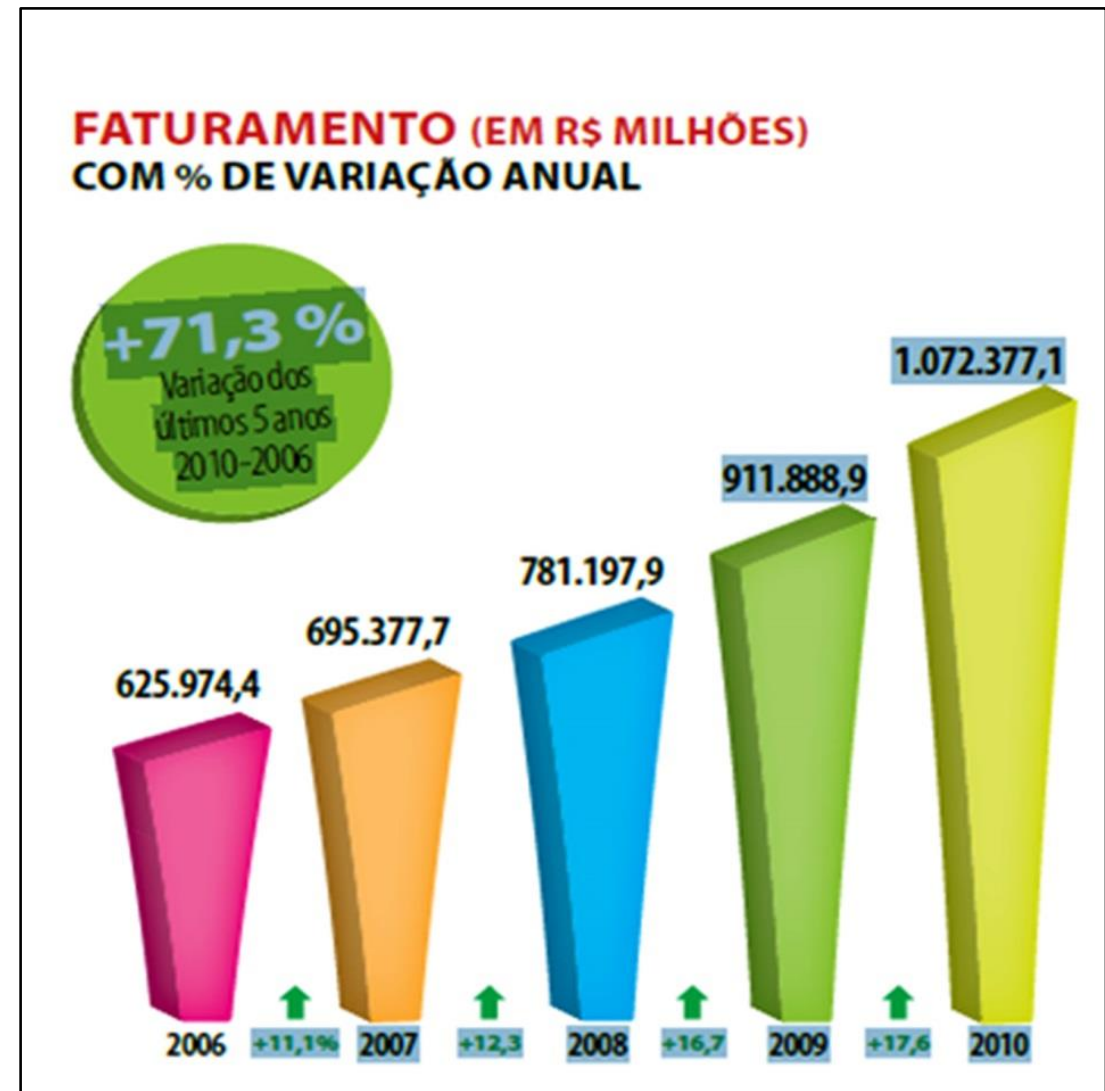

Figura 7: Faturamento das empresas de alvejante e água sanitária (Abipla, 2013).

De acordo com a FIG. 8, considerando somente o volume de água sanitária de 2006 a 2008 e faturamento têm-se outros dados (Freedom, 2013).
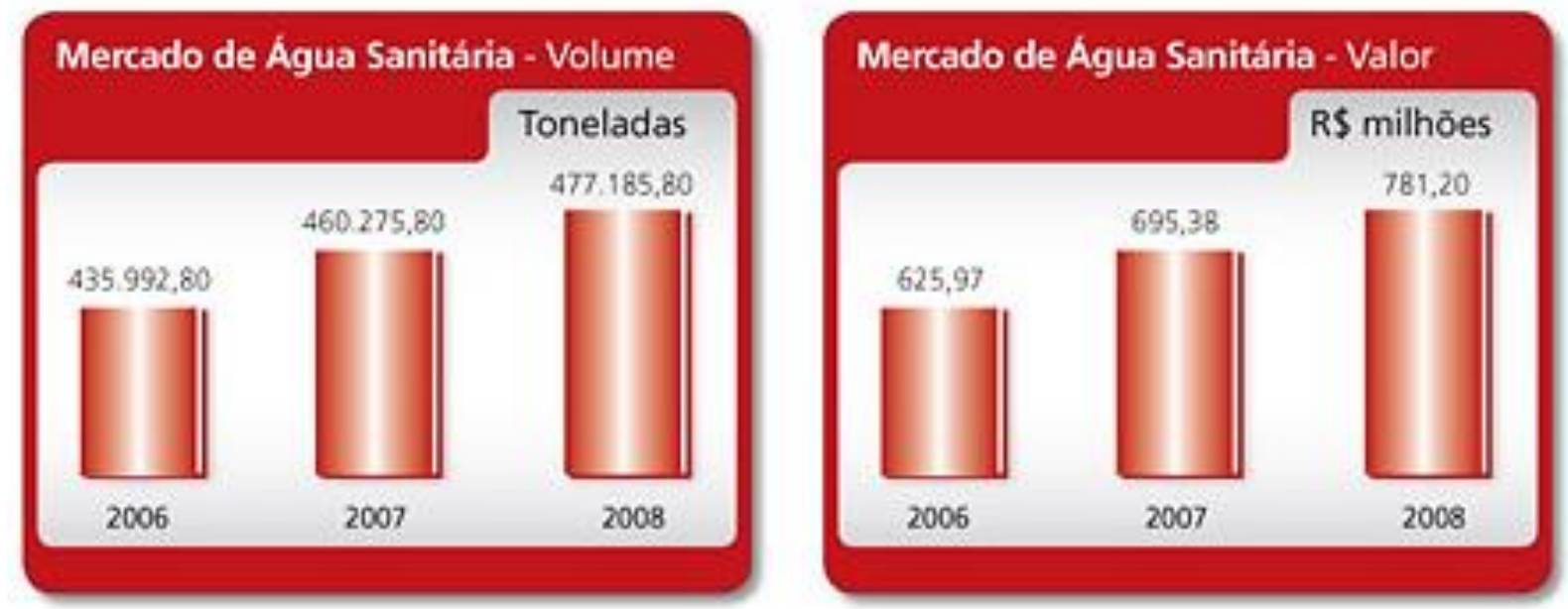

Figura 8: Dados do volume e faturamento de água sanitária (Freedom, 2013). 


\subsection{A formação de Trihalometanos (THM) pelo uso de derivados clorados}

No processo de desinfecção da água para a indústria farmacêutica, farmácias magistrais e abastecimento público com produtos à base de cloro, há possibilidade de formação de substâncias potencialmente cancerígenas.

Tais substâncias são denominadas subprodutos da cloração, dentre elas destacam-se os trihalometanos (THM), que se originam das reações entre o cloro e as substâncias orgânicas, os ácidos húmicos e fúlvicos, presentes na água, ou compostos como $\beta$-dicetonas e compostos semelhantes, como resorcinol também favorecem a formação dos trihalometanos (Sampaio Pereira, 1989).

As estruturas a seguir são capazes de formar THMS (Sampaio Pereira, 1989).

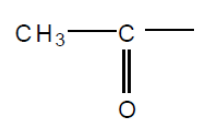

Acetila<smiles>[R]C(=O)CC([R])=O</smiles>

Dicetona<smiles>O=C1CCCC(=O)C1</smiles>

1,3 - dicetona ciclohexano

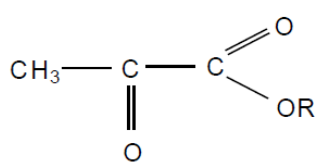

Beta-cetoester

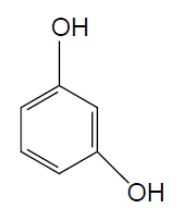

Metahidroxifenol (Resorcinol)

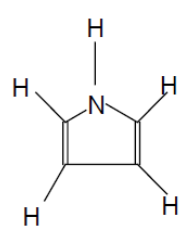

Pirrol

A estrutura do tipo resorcinol, na estrutura do material húmico, é a que mais favorece a formação dos THMs. A estrutura do pirrol tem importância por 
ocorrer em muitas substâncias naturais, como por exemplo, a clorofila (Rook, 1979).

O Triclorometano, Bromodiclorometano, Dibromoclorometano e Tribromo-metano são os principais compostos oriundos dessas reações.

A partir de 1974, quando nos EUA, estudos mostraram pela primeira vez a correlação positiva entre águas de abastecimento público e câncer, várias pesquisas foram desenvolvidas, das quais se destaca aquela realizada pela U.S. Environmental Protection Agency (EPA) em 113 estações de tratamento d'água (ETA) (Macêdo, 2002).

Trihalometanos foram encontrados em todas as ETAs que utilizavam derivados clorados nos processos de desinfecção (Bellar et al., 1974; Bun et al. 1975; Balster e Borzelleca, 1982; Melnick, 1987; Melnick, 1989).

Em 1979 a EPA estabeleceu $100 \mu \mathrm{g} \mathrm{L}^{-1}$ (micrograma por litro) como a concentração máxima total de trihalometano (THM) em água para abastecimento público, em 1998 a EPA estabeleceu como valor final para concentração máxima $80 \mathrm{\mu g} \mathrm{L}^{-1}$ (Macêdo, 2001). Espera-se uma redução futura, em um segundo estágio, para $40 \mathrm{\mu g} \mathrm{L}^{-1}$ (Ferreira Filho, 2001).

Com a divulgação a partir de 1982 da presença de THM em refrigerantes (Abdel-Rahman, 1982; McNeal et al., 1995) e da confirmação da correlação entre câncer e THM, alguns países adotaram um valor máximo para TTHM em águas de abastecimento público, sendo o Canadá $350 \mu \mathrm{g} \mathrm{L}^{-1}$, a Alemanha $25 \mu \mathrm{g} \mathrm{L}^{-1}$, a Holanda $75 \mu \mathrm{g} \mathrm{L}^{-1}$ e a França $10 \mu \mathrm{g} \mathrm{L}^{-1}$. No Brasil, somente a partir de 1990, pela Portaria no 36, de 19 de janeiro de 1990, do Ministério da Saúde, ficou estabelecido que o valor máximo permitido (VMP) é $100 \mu \mathrm{g} \mathrm{L}^{-1}$, este valor foi mantido pelas Portarias 1469 e 2914, também do Ministério da Saúde (Brasil, 1990; Brasil, 2001; Brasil, 2011).

A Portaria 36 ressaltava que o valor de $100 \mu \mathrm{g} \mathrm{L}^{-1}$ poderia ser revisto, em função de estudos toxicológicos em andamento, que nunca foram apresentados e apesar do órgão americano, EPA, reduzir em 20\% o valor permitido para TTHM, a Portaria 2914 mantém $100 \mathrm{mg} \mathrm{L}^{-1}$, ou seja, não levando 
em consideração os estudos realizados pelo órgão ambiental dos Estados Unidos.

Os THMs poderão chegar até o homem através da: i) ingestão de água; ii) Lavagem de roupas e louças; iii) Durante o banho; iv) através do uso de piscinas. A inalação de clorofórmio durante um banho de ducha, por 9 minutos pode chegar a ser 6 vezes maior que a ingestão da mesma água tratada durante 24 horas (Tominaga e Midio, 1999).

Nas piscinas aquecidas existe um risco de exposição maior que nas piscinas de temperatura ambiente. Em estudos realizados nos Estados Unidos, em ambiente, foram detectados níveis de bromofórmio $\left(37,0 \mu \mathrm{g} \mathrm{m} \mathrm{m}^{-3}\right)$, dibromoclorome-tano $\left(32,0 \mu \mathrm{g} \mathrm{m}^{-3}\right)$ e bromodicloromento $\left(7,4 \mu \mathrm{g} \mathrm{m}^{-3}\right)$. Já 0 clorofórmio apresenta níveis que variam de 0,07 a $3,8 \mu^{-3} \mathrm{~m}^{-3}$ (Tominaga e Midio, 1999).

A importância dos THMs em nível mundial prende-se ao fato de que, além de serem considerados carcinogênicos, são também indicadores da possível presença de outros compostos organoclorados (ácido acético clorado, haloacetonitrilos, cloropicrin, clorofenóis, cloropropanonas), também resultantes do processo de cloração das águas e mais perigosos que os próprios THMs. Em função dos riscos, a EPA estabeleceu em dezembro de 1993 que 30 substâncias químicas são consideradas nocivas à saúde, dentre essas se destacam os THMs, cuja tolerância foi considerada na época como sendo "zero", considerada extremamente rígida e desnecessária (Gray, 1994).

Quanto à formação de trihalometanos deve-se ressaltar que a pesquisa realizada por Macêdo (1997), comparou a formação de THM quando no processo de desinfecção se utilizou o HPCS (Hipoclorito de sódio) e o NaDCC (dicloroisocianurato de sódio), demonstrando que a probabilidade de formação de THM é muito pequena ou nula, ou seja, os níveis formados não são significativos com relação à saúde pública (Macêdo, 1997).

A reação para formação dos THMs em condições naturais não é instantânea. Isto ocorre porque vários fatores influem simultaneamente na 
velocidade, não sendo possível, portanto, predizer o tempo de reação em função da complexidade das reações e da mistura de estruturas desconhecidas.

É aceito o princípio de que quanto maior o tempo de contato maior será a probabilidade de formação dos THMs. Como regra geral, aceita-se que quanto maior a temperatura maior será a probabilidade de formação do THM. A presença de brometos e iodetos facilita a formação dos trihalometanos, em cuja constituição entra o bromo e o iodo. Em águas superficiais brasileiras, a maior contribuição tem sido do bromodiclorometano (16\%) e do dibromoclorometano (3\%).

O tribromometano e os trihalometanos iodados não têm sido detectados. Com o aumento do pH espera-se uma maior formação de THM, em função da reação clássica "halofórmica" ser catalisada por uma base. Quanto maior a concentração de ácidos húmicos maior será a formação de THM. A maior a concentração de $C R L$ (cloro residual livre) maior será a concentração final de THM e que o CRC (cloro residual combinado) constituído pelas cloraminas tem menor poder de ataque às substâncias húmicas, levando à menor formação de THM (Symons et al., 1981; Johnson e Jensen, 1983).

Além disso, MACÊDO (1997) constatou que cianetos liberados em solução pelo $\mathrm{NaDCC}$ são irrelevantes no aspecto de saúde pública. A legislação vigente indica como valor máximo permitido (VMP) dessa substância na água potável $0,1 \mathrm{mg}$ de $\mathrm{CN}^{-} \mathrm{L}^{-1}$. O valor máximo obtido foi $0,01 \mathrm{mg} \mathrm{L}^{-1}$ para amostras de água na ETA após cloração com HPCS; as demais amostras apresentaram valores inferiores.

A Resolução oㅜ 150, de 28 de maio de 1999, da Agência Nacional de Vigilância Sanitária que autoriza a utilização do ácido dicloroisocianúrico e seus sais de sódio e potássio como princípio para desinfecção de água para consumo humano, confirma as conclusões do trabalho realizado por MACÊDO (1997).

Na TAB. 9 são apresentados os diversos tipos de derivados clorados utilizados no processo de desinfecção, através da atribuição de notas, variando de 1 até 4 , permite uma comparação entre os diversos produtos. 
Tabela 9: Comparação por escala numérica de 0 a 4, entre várias qualidades dos principais derivados clorados disponíveis no mercado.

\begin{tabular}{|c|c|c|c|c|c|c|c|c|c|c|c|c|c|c|c|c|c|c|c|c|}
\hline Produto & & $\begin{array}{l}\text { poc } \\
\text { cé } \\
\text { íqui }\end{array}$ & $\begin{array}{l}\text { Iori } \\
\text { Ílcic } \\
\text { do }\end{array}$ & & & & poc & $\begin{array}{l}\text { lori } \\
\text { Ici } \\
\text { Iot }\end{array}$ & & & & sól & $\begin{array}{l}\text { clor } \\
\text { nur } \\
\text { ódi } \\
\text { do } 6\end{array}$ & $\begin{array}{l}0 \\
\text { to o } \\
5 \%)\end{array}$ & & & $\begin{array}{l}\text { cido } \\
\text { soci } \\
\text { sóli }\end{array}$ & $\begin{array}{l}\text { tri } \\
\text { ianú } \\
\text { do } 9\end{array}$ & $\begin{array}{l}\text { clor } \\
\text { |rico } \\
5 \%\end{array}$ & \\
\hline Nota para o item & 0 & 1 & 2 & 3 & 4 & 0 & 1 & 2 & 3 & 4 & 0 & 1 & 2 & 3 & 4 & 0 & 1 & 2 & 3 & 4 \\
\hline Característica & & & & & & & & & & & & & & & & & & & & \\
\hline $\begin{array}{l}\text { Quanto à } \\
\text { solubilidade }\end{array}$ & & & & & & & & & & & & & & & & & & & & \\
\hline $\begin{array}{l}\text { Quanto à } \\
\text { estabilidade do } \\
\text { produto }\end{array}$ & & & & & & & & & & & & & & & & & & & & \\
\hline $\begin{array}{l}\text { Não perde o cloro } \\
\text { ativo }\end{array}$ & & & & & & & & & & & & & & & & & & & & \\
\hline Não altera o pH & & & & & & & & & & & & & & & & & & & & \\
\hline $\begin{array}{l}\text { Não cria } \\
\text { incrustações }\end{array}$ & & & & & & & & & & & & & & & & & & & & \\
\hline $\begin{array}{l}\text { Menor probabilidade } \\
\text { de geração de } \\
\text { subprodutos }\end{array}$ & & & & & & & & & & & & & & & & & & & & \\
\hline Segurança & & & & & & & & & & & & & & & & & & & & \\
\hline Total de pontos & & & 7 & & & & & 3 & & & & & 28 & & & & & 20 & & \\
\hline $\begin{array}{l}\text { Teor de r } \\
\text { 0- Péssir } \\
\text { Fonte: ( }\end{array}$ & & & & & & & & & & & & & & & & & & & & \\
\hline
\end{tabular}

\subsection{Produtos à base de cloro utilizados em outros países com finalidade de desinfecção e limpeza}

Um exemplo de alternativa à água sanitária utilizado em indústria de alimentos é o dióxido de cloro $\left(\mathrm{ClO}_{2}\right)$ que é um agente de desinfecção permitido pela legislação de água alemã. Ele é utilizado desde meados da década de 40 nos Estados Unidos e desde os anos 50 pelas empresas públicas alemãs fornecedoras de água potável. Paralelo ao seu amplo espectro de atuação, também possui uma extraordinária eficácia na eliminação de biofilme e oferece uma proteção bacteriostática de longa duração (Cervesia, 2013).

Esse composto tem sido utilizado em mais de $80 \%$ das cervejarias alemãs e várias empresas privadas do segmento de bebidas e alimentação já utilizam esta tecnologia no Brasil (Cervesia, 2013). 


\subsection{Informações gerais sobre produtos saneantes - Legislação Brasileira}

De acordo com a ANVISA (1997), os produtos conhecidos como saneantes são: Substâncias ou preparações destinadas à higienização, desinfecção ou desinfestação domiciliar, em ambientes coletivos ou públicos, em lugares de uso comum e no tratamento de água. A função dos saneantes é eliminar sujeiras, germes e bactérias, evitando assim, o aparecimento de doenças causadas pela falta de limpeza dos ambientes.

Podem ser:

a) Bactericidas - são antibióticos que têm efeito letal sobre a bactéria, ou seja, destroem a bactéria (por meio de diversos mecanismos: destruição da parede celular, inibição da síntese proteica, inibição na síntese do ácido fólico), interrompendo assim a reprodução da bactéria, inibindo seu metabolismo e no final eliminando a bactéria.

b) Sanitizantes - são agentes ou produtos que reduzem o número de bactérias a níveis seguros de acordo com as normas de saúde.

c) Desinfetantes - são formulações/produtos que têm na sua composição substâncias microbicidas que apresentam efeito letal para todos os microrganismos patogênicos, porém não necessariamente apresentam efeito letal para todas as formas microbianas esporuladas em objetos e superfícies inanimadas.

d) Esterilizantes - são formulações que têm na sua composição substâncias microbicidas e apresentam efeito letal para microrganismos esporulados e não esporulados.

e) Alvejantes - qualquer substância com ação química, oxidante ou redutora, que exerce ação branqueadora.

Agentes sanitizantes químicos (ANVISA, 2007) são largamente conhecidos e aplicados. Podem-se citar: álcoois (etanol), aldeídos (glutaraldeído), 
haletos (gás cloro, hipocloritos, iodo e Cloramina-T, dicloroisocianurato de sódio), fenóis, compostos de amônio quaternário, entre outros.

A Resolução da Diretoria Colegiada, RDC, $n^{\circ}-14$, da ANVISA de 28 de fevereiro de 2007, no capítulo I item 3 "Definições/Glossário", apresenta uma lista de termos comumente utilizados nos textos da área, mas que nem sempre são utilizadas corretamente. Assim, no presente texto, os termos são utilizados no sentido da sua definição nessa RDC da ANVISA. Não se pretende necessariamente utilizar substâncias desinfetantes, uma vez que com a sanitização a condição de segurança já é alcançada.

Este trabalho propõe o uso do dicloroisocianurato de sódio, NaDCC, número CAS 51580-86-0, como principal agente sanitizante químico. O NaDCC já é utilizado para tratamento de águas de piscinas, é utilizado em estações de tratamento de água para desinfecção secundária e é aprovado pela Agência Nacional de Vigilância Sanitária, ANVISA, para tratamento de água para consumo humano (ANVISA, 1999). A ação sanitizante do produto é obtida pela geração de gás cloro, cujas equações químicas são apresentadas mais adiante.

Numa escala mais abrangente, é preciso considerar a inserção de um projeto como este num cenário onde atuam e competem vários atores. Dentre os requisitos de desempenho para acompanhamento deste projeto, destacam-se os fundamentos do "Triple Botton Line" que se baseiam na correlação entre os aspectos Ambiental, Social e Econômico. A convergência Ambiental será resultado da redução do consumo de água potável utilizada para descarga de dejetos humanos. O cenário Social ao qual se pretende contribuir será resultado da inclusão de uma fração da população no projeto de tarifas sociais de baixo consumo de água, atualmente não possível devido, em parte, ao grande consumo de água nos sistemas sanitários e, finalmente, os resultados Econômicos deverão ser consequência da redução do valor da conta de consumo de água e a consequente transferência para outras demandas (Savitz, 2006).

A avaliação de desempenho adequada partirá do estabelecimento de indicadores ambientais restritos que permitam inferir a evolução dos parâmetros de qualidade ambiental relacionados aos efeitos da alteração da frequência de 
descarga em residências e a introdução de substâncias químicas não consideradas no processo tradicional. Os indicadores são considerados restritos uma vez que foram resultados de uma pequena amostra da população que eventualmente irá aderir ao novo comportamento.

Assim, a sensibilidade desses indicadores ambientais deverá ser suficiente para se avaliar a qualidade (situação) do ambiente pontual (alterações nas condições químicas e sanitárias/microbiológicas da bacia sanitária). Numa escala mais abrangente, deverão ser projetadas as quantidades e possíveis efeitos além desse ambiente pontual, ou seja, discutir as consequências no meio ambiente externo e os possíveis impactos nas estações de tratamento de água e de esgoto.

Os indicadores ambientais, portanto, deverão possuir capacidade de síntese, isto é, alicerçados em dados e informações confiáveis, deverão representar o mais fielmente o cenário antes e depois da aplicação do processo aqui estudado. Devem, também, estar em bases que permitam ser correlacionados com as políticas ambientais vigentes. Focando na adesão pelos consumidores e na continuidade dessa alteração, os indicadores, quer sejam os parâmetros ou os valores em si, devem ser compreensíveis pela maior parte de seus usuários e não apenas termos, definições e números que não promovam o engajamento dos usuários comuns (Merico, 1997).

Espera-se que se possa contribuir para a socialização da distribuição dos benefícios do melhor uso da água. Mesmo que segmentado, a racionalização do uso da água permite que a distribuição da água tratada seja capilarizada alcançando aquela fração da população ainda desprovida desse benefício. Certamente, o acesso a esse recurso público irá impactar no orçamento dessas famílias. Porém, os benefícios com menores gastos com a saúde e a sensível melhoria na qualidade de vida, irão neutralizar os gastos iniciais elevando essa população a outro patamar de humanidade.

Finalmente, o lado econômico será percebido inicialmente pelas famílias que aderirem a esse conceito com a redução dos gastos com o consumo de água. Não é possível, neste momento, projetar valores financeiros, mas 
prováveis resultados deste projeto. É possível sim, como apresentado anteriormente, teorizar a partir de situações hipotéticas. Essas situações hipotéticas são estimulantes o bastante para iniciar um projeto dessa natureza sem, entretanto, perder o contato com a realidade. 


\section{METODOLOGIA}

O conceito estudado neste projeto baseia-se em reações de substâncias com propriedades sanitizantes para estabelecer um ambiente seguro para a saúde e também com propriedades inibidoras de cor e odor, deixando um ambiente no interior da bacia sanitária com aspecto e odor agradável, mesmo usando várias vezes para urinar antes do acionamento da descarga.

Embora a urina em um indivíduo saudável seja estéril, prioritariamente, os organismos a serem combatidos foram aqueles mais comuns no ambiente limitado pela bacia sanitária. São eles, mas não exclusivamente: Escherichia coli e os coliformes termotolerantes e totais, dos gêneros Giardia spp e Cryptosporidium spp.

No The Merck Index (Merck, 2006) verificou-se uma enorme variedade de substâncias com propriedades sanitizantes, desinfetantes e desodorizantes. Essas substâncias são potencialmente viáveis para o presente trabalho, mas todas devem ser avaliadas quanto aos danos ao meio ambiente e à estação de tratamento.

Foram testadas as associações de substâncias orgânicas e inorgânicas na condição de maior pureza, de fácil aquisição e custos baixos, produzidos no Brasil, tais como: sais, óxidos, hidróxidos, solventes, ácidos, enzimas, corantes, essências, e outros, que atendam as necessidades especificadas.

A Resolução da Diretoria Colegiada, RDC, $n^{\circ}$ 14, da ANVISA de 28 de fevereiro de 2007, no capítulo I item 3 "Definições/Glossário", apresenta uma lista de termos comumente utilizados nos textos da área, mas que nem sempre são utilizadas corretamente. Assim, no presente texto, os termos são utilizados no sentido da sua definição nessa RDC da ANVISA. Não se pretende necessariamente utilizar substâncias desinfetantes, uma vez que com a sanitização a condição de segurança já é alcançada (ANVISA, 2007). 
Cada substância deverá ser testada de maneira a reagir com os componentes da urina em quantidades tendo como base a média ou intervalo esperado estequiometricamente (urina normal), de modo a obter uma formulação adequada ao tratamento proposto.

Os produtos e subprodutos das reações de neutralização da urina deverão atender:

- A Resolução - RDC da ANIVSA no 184, de 22 de outubro de 2001 e

- Os padrões de emissão da Resolução do Conselho Nacional do Meio Ambiente, CONAMA, nํㅜ 357/05 (Brasil, 2005), revisado pela Resolução CONAMA n- 430/2011 (Brasil, 2011), e, no Estado de São Paulo, também atender aos padrões de emissão estabelecidos nos artigos 18 ou $19 \mathrm{~A}$ do Decreto Estadual nº 8468/76 (São Paulo, 1976).

As ações de desempenho do produto para destruição dos agentes bacteriológicos no efluente também foram avaliadas em conformidade com a legislação vigente anteriormente citada.

Cabe ressaltar que uma das ideias do projeto é alcançar o objetivo com um mínimo de impacto ambiental pelo uso das substâncias ou produtos químicos a serem propostas. Não faz sentido algum resolver um problema e criar ou aumentar outro.

\subsection{Metodologia do processo para produção de comprimido sanitizante}

A forma física e dimensões do produto deverão ser atraentes e práticos para o uso. Pretende-se que o produto tenha o aspecto de um comprimido. A princípio, com essas dimensões, a quantidade do princípio ativo deverá ser suficiente para um período de residência/ação/tolerância estética.

Para o desenvolvimento do produto foram adotados processos de fabricação compatíveis com matérias primas acessíveis e rotas simples capazes de viabilizar a produção com baixos custos. $O$ processo de fabricação do 
comprimido sanitizante de uso em bacia sanitária será executado em duas fases de preparação.

A primeira fase consiste na mistura dos componentes que se apresentam na forma de pó, que foram homogeneizados mecanicamente. Procurar-se-á utilizar matérias primas uniformizadas quanto à granulometria para a fabricação dos comprimidos por dupla compressão.

Todos os componentes da formulação foram misturados usando metodologia descrita no manual de Boas Práticas de Fabricação da ANVISA (ANVISA, 2010). Para obter-se o processo via úmida, o lubrificante será adicionado após obtenção do granulado, assim como parte do agente desintegrante.

Na segunda fase, a mistura irá para um processo de prensagem, em prensa apropriada, para se obter um produto com a configuração de um comprimido. No mercado existem diversas máquinas de compressão (por exemplo, o Modelo FABBE) que podem ser utilizadas no processo. Após a prensagem o comprimido será embalado em embalagem tipo blister de polietileno.

No processo de fabricação foram avaliados os seguintes itens:

- aspecto das pastilhas;

- forma;

- condições de secagem do granulado;

- tempo de mistura;

- velocidade e

- força de compressão.

Nosso objetivo é avaliar o processo de fabricação para os comprimidos, aplicando os métodos clássicos descritos na farmacopéia brasileira: granulação úmida seguida de dupla compressão utilizando componentes com alto índice de compressibilidade. 


\subsection{Equipamentos utilizados em escala de produção}

Numa perspectiva de conformação do produto em formato de comprimidos, foi realizada uma pesquisa sobre os equipamentos e métodos para essa produção.

Os equipamentos que foram utilizados na produção dos comprimidos sanitizantes, são:

- compressora rotativa de 32 punções ou equivalente;

- envelopadora dupla;

- granulador rotativo cônico;

- misturador em V 100/180 L.

$\mathrm{Na}$ instalação do processo produtivo são observadas todas as características técnicas descritas pelo fabricante do equipamento e o local de instalação seguirá todos os preceitos descritos no manual de Boas Práticas de Fabricação da ANVISA.

Na qualificação de operação da compressora são analisadas:

- a regulagem da força de compressão;

- a guia de regulagem do granulado;

- o controle do aspirador de pó;

- o acionamento da coroa de emergência;

- a regulagem do extrator de comprimidos e;

- a velocidade de compressão.

Para o granulador são analisados:

- o tamanho de abertura das malhas;

- o formato das malhas e;

- a distribuição de tamanho de partículas. 
Para o misturador em V são analisados:

- a velocidade;

- a carga e;

- o tempo.

Para a envelopadora são analisadas as características funcionais do equipamento.

Os testes para a qualificação de desempenho são:

- desintegração;

- diâmetro;

- dureza;

- flexibilidade;

- massa média para a compressora.

Para o granulador são verificados testes de capacidade de granulação. Para o misturador em $V$ são testadas a uniformidade de conteúdo e a capacidade de volume. Para a envelopadora são realizados testes de infiltração.

Os equipamentos e instrumentos utilizados nos testes são prévia e devidamente calibrados. As normas utilizadas na fabricação são as descritas no manual de Boas Praticas de Fabricação da ANVISA, que define os critérios da produção com os seguintes objetivos de padronizar a reprodutibilidade e validar o processo em que se especificam os parâmetros que foram rigorosamente cumpridos durante a rotina de produção.

\subsection{Formulação básica do produto}

O produto sanitizante será composto por substâncias capazes de eliminar agentes responsáveis pela cor característica da urina, com poder de neutralização de odores e ação bactericida. 
Os componentes previamente estudados foram o dicloroisocianurato de sódio e o bicarbonato de sódio, ambos já aplicados em muitas formulações de forma isolada, sendo este segundo, utilizado em comprimidos efervescentes. A adequação da formulação passará por um criterioso estudo e pesquisa de forma a garantir além da eficiência do produto, o atendimento a todos os requisitos legais já citados anteriormente. Outras substâncias foram testadas juntamente com os 2 agentes principais $\left(\mathrm{NaHCO}_{3}\right.$ e $\left.\mathrm{NaDCC}\right)$, a fim de obter o melhor desempenho do produto sanitizante.

A presença de NaDCC, dicloroisocianurato de sódio, também conhecido como Cloro Orgânico, contém de 55 a 60\% de cloro disponível cuja ação bactericida (sanitizante) se dá no intervalo de pH entre 6 e 10.

Diversos estudos demonstram a grande eficiência da utilização do NaDCC como agente de desinfecção em unidades de tratamento de água e este produto está regulamentado pela ANVISA por meio das Portarias $n^{\circ} 152$, de 26/02/1999 e $\mathrm{n}^{\circ}$ 150, de 28/05/1999.

O princípio ativo NaDCC, FIG. 9, é acídico, portanto tende a baixar o $\mathrm{pH}$ inicial da água, ao contrário do hipoclorito, que por ser alcalino, tende a aumentar o pH da água.

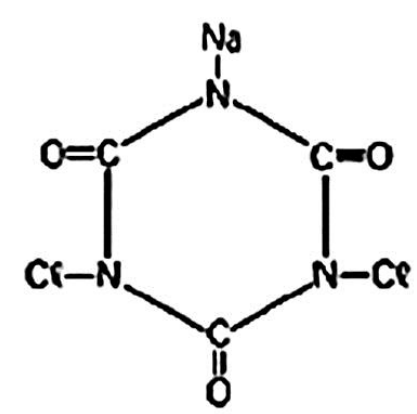

Figura 9: Dicloroisocianurato de sódio $\left(\mathrm{C}_{3} \mathrm{Cl}_{2} \mathrm{~N}_{3} \mathrm{NaO}_{3}\right)$.

Na reação de hidrólise do $\mathrm{NaDCC}$, o anel cianúrico está representado como CA nas reações de 1 a 4 .

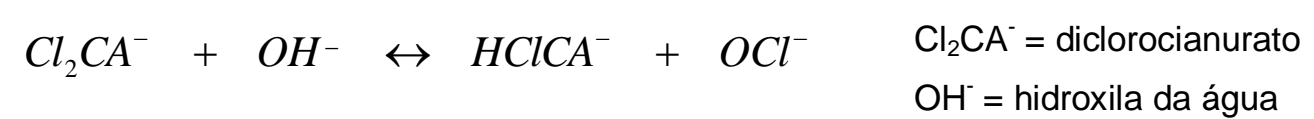




$$
\begin{aligned}
& \mathrm{HCICA}^{-}=\text {monoclorocianurato } \\
& \mathrm{OCl}^{-}=\text {hipoclorito } \\
& \mathrm{HClCA}^{-}+\mathrm{OH}^{-} \leftrightarrow \mathrm{H}_{2} \mathrm{CA}^{-}+\mathrm{OCl}^{-} \quad \mathrm{HClCA} \text {-=monoclorocianurato } \\
& \mathrm{OH} \text { - = hidroxila da água } \\
& \mathrm{H}_{2} \mathrm{CA}-=\text { cianurato } \\
& \mathrm{OCl}^{-}=\text {hipoclorito } \\
& \mathrm{HOCl} \leftrightarrow \mathrm{H}^{+}+\mathrm{OCl}^{-} \\
& \mathrm{HOCl}=\text { ácido hipocloroso } \\
& \mathrm{H}^{+}=\text {hidrogênio } \\
& \mathrm{OCl} \text { - = hipoclorito } \\
& H_{3} C A \leftrightarrow H^{+}+H_{2} C A^{-} \\
& \mathrm{H}_{3} \mathrm{CA}=\text { ácido cianúrico } \\
& \mathrm{H}^{+}=\text {hidrogênio } \\
& \mathrm{H}_{2} \mathrm{CA}^{-}=\text {cianureto }
\end{aligned}
$$

$\mathrm{Na}$ forma de solução, uma fração do NaDCC irá gerar cloro livre conforme as reações apresentadas. Há ainda a formação de mono ou dicloroisocianurato combinados devido às reações incompletas da fração remanescente. As reações do cloro livre são muito favoráveis na oxidação de micro-organismos, materiais orgânicos ou nitrogenados, sendo o ácido hipocloroso liberado, tendendo estabilizar o equilíbrio em compensação à perda de consumo do cloro livre.

A hidrólise dos principais derivados clorados é representada pelas equações (5 a 9), (Dychdala, 1977; Tchobanoglous e Burton, 1991; Meyer, 1994; Marriot, 1995; Andrade e Macêdo, 1996).

$$
\begin{aligned}
& \underset{\text { (gás cloro) }}{\mathrm{Cl}_{2}+\mathrm{H}_{2} \mathrm{O}} \rightleftharpoons \mathrm{HClO}+\mathrm{H} \\
& \underset{\text { (hipoclorito de sódio) }}{\mathrm{NaClO}}+\mathrm{H}_{2} \mathrm{O} \rightleftharpoons \mathrm{Na}^{+}+\mathrm{ClO}^{-}+\mathrm{H}_{2} \mathrm{O} \\
& \mathrm{Na}^{+}+\mathrm{ClO}^{-}+\mathrm{H}_{2} \mathrm{O} \rightleftharpoons \mathrm{HCl}+\mathrm{Na} \\
& \underset{\text { (hipoclorito de cálcio) }}{\mathrm{Ca}(\mathrm{ClO})_{2}+\mathrm{H}_{2} \mathrm{O} \rightleftharpoons \mathrm{Ca}^{2+}+2 \mathrm{ClO}^{-}+\mathrm{H}_{2} \mathrm{O}} \\
& \mathrm{Ca}^{2+}+2 \mathrm{ClO}^{-}+2 \mathrm{H}^{+}+2 \mathrm{OH}^{-} \rightleftharpoons 2 \mathrm{HClO}+\mathrm{Ca}(\mathrm{OH})_{2}+\mathrm{H}_{2}
\end{aligned}
$$

Com relação ao dicloroisocianurato de sódio (FIG. 10), deve-se ressaltar que a representação por duas estruturas se deve ao fato de que na 
produção do referido produto parte-se do ácido cianúrico que pode apresentar duas formas tautoméricas: a) a forma enol denominada ácido cianúrico; e b) a forma ceto, o ácido isocianúrico, cuja diferença está na posição de ligação do hidrogênio, que no caso do ácido cianúrico está ligado ao oxigênio e no ácido isocianúrico está ligado ao nitrogênio (Clearon, 1997).

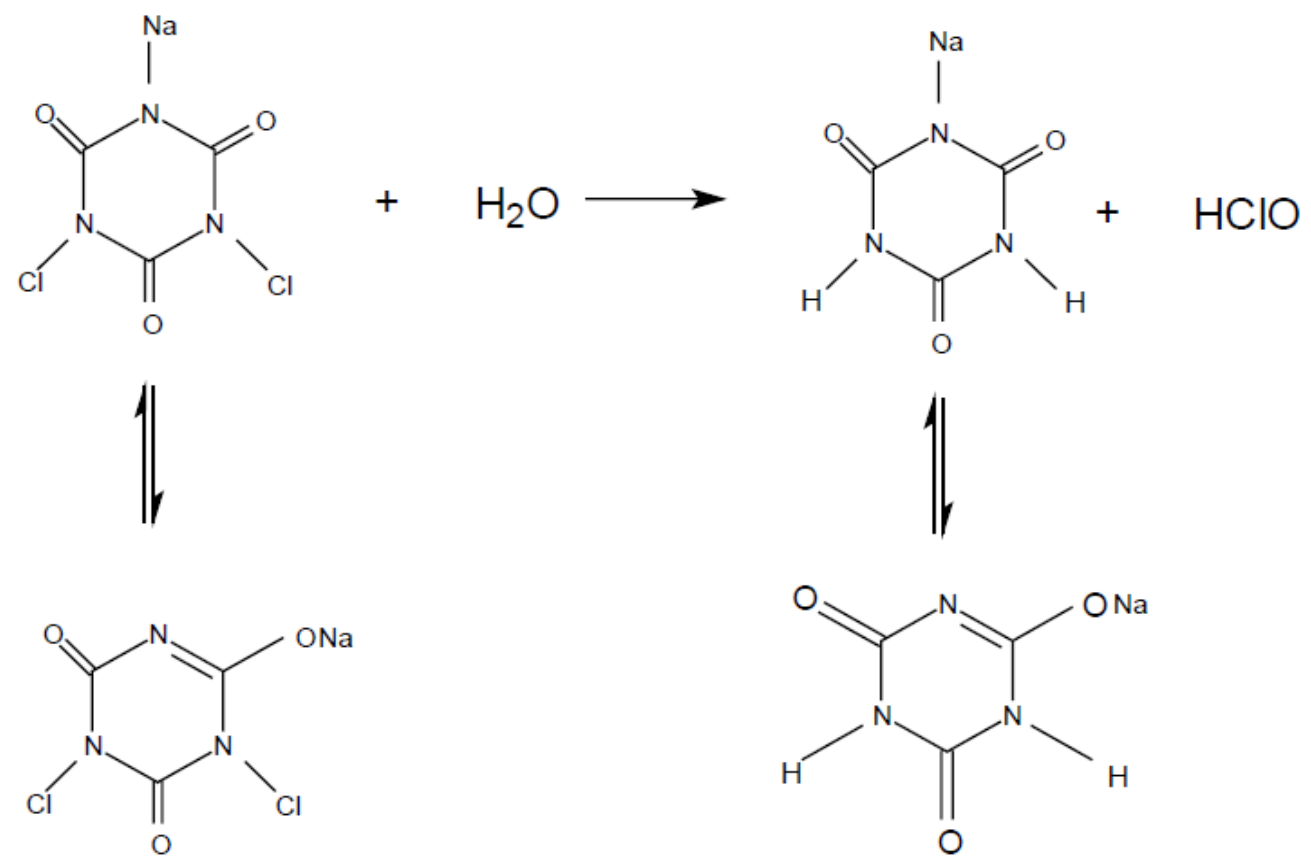

Figura 10: Dicloroisocianurato de Sódio.

Optou-se por utilizar o nome dicloroisocianurato de sódio em função de que no Brasil todas as empresas apresentam nos seus documentos técnicos a estrutura química na forma com o sódio ligado no nitrogênio.

A ação oxidante e sanitizante dos derivados clorados é controlada pelo ácido hipocloroso $(\mathrm{HClO})$, um produto resultante da hidrólise da substância clorada (equações 1 a 4). O $\mathrm{HClO}$ e $\mathrm{ClO}^{-}$é denominado de cloro residual livre (CRL) (Macêdo, 2000). O ácido hipocloroso é um ácido fraco, cuja constante de dissociação (pKa), a $30^{\circ} \mathrm{C}$, é $3,18 \times 10^{-8}$ e que em solução aquosa se dissocia para formar o íon hidrogênio e o íon hipoclorito (equação 10).

$$
\mathrm{HClO} \rightleftharpoons \mathrm{ClO}^{-}+\mathrm{H}^{+}
$$


Portanto, os compostos clorados são mais efetivos em valores de $\mathrm{pH}$ baixos quando a presença de ácido hipocloroso é dominante, ou seja, em pH acima de 8,5 a concentração de $\mathrm{HClO}$ em solução é tão pequena que já não se teria uma ação sanificante eficiente, FIG.11.

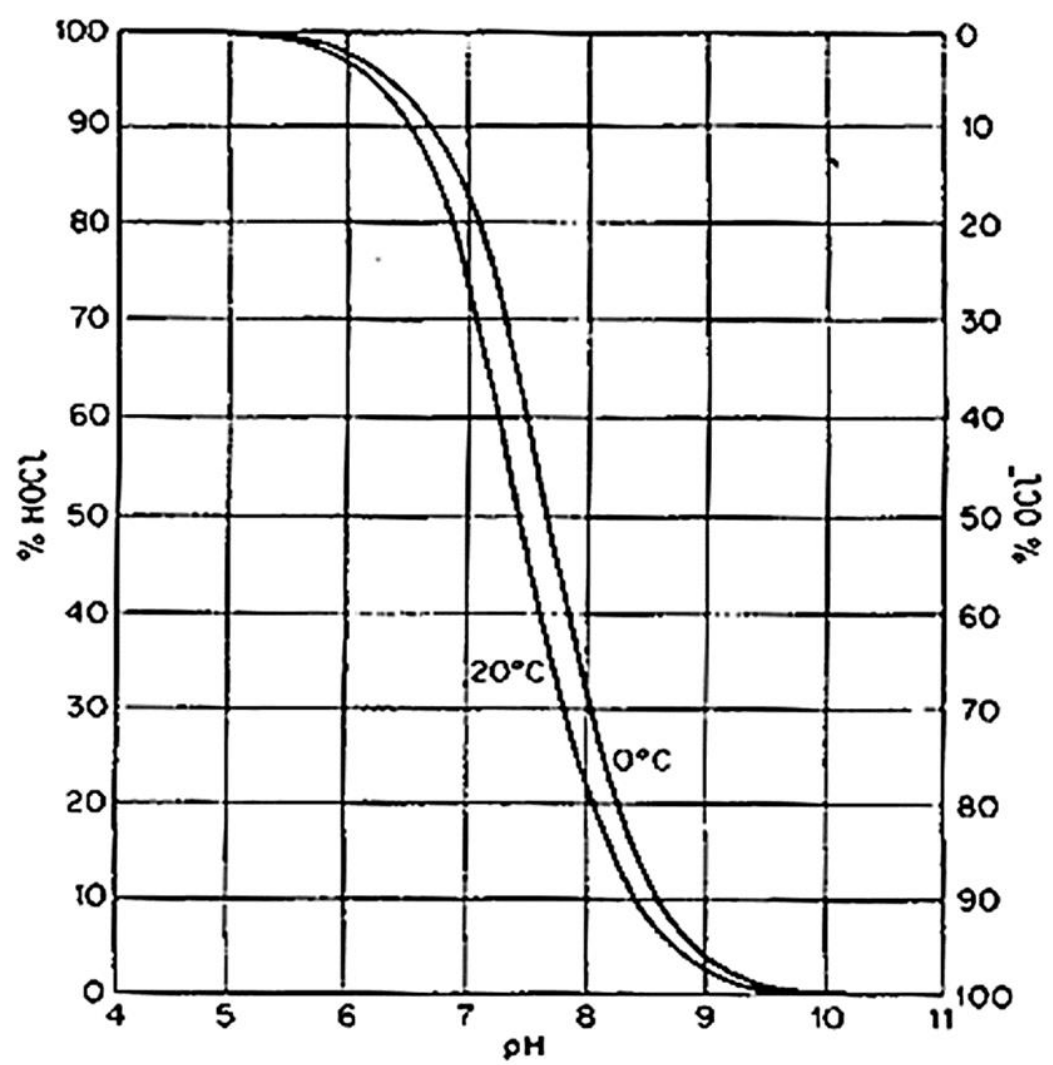

Figura 11: Efeito do pH na distribuição de ácido hipocloroso e íon hipoclorito na água. (McPherson, 1993).

A urina humana é constituída de 2 a $5 \%$ em ureia. Essa é a forma utilizada pelo metabolismo do organismo para eliminar os resíduos nitrogenados indesejáveis produzidos a partir das proteínas. (Peruzzo e Canto, 1999). 


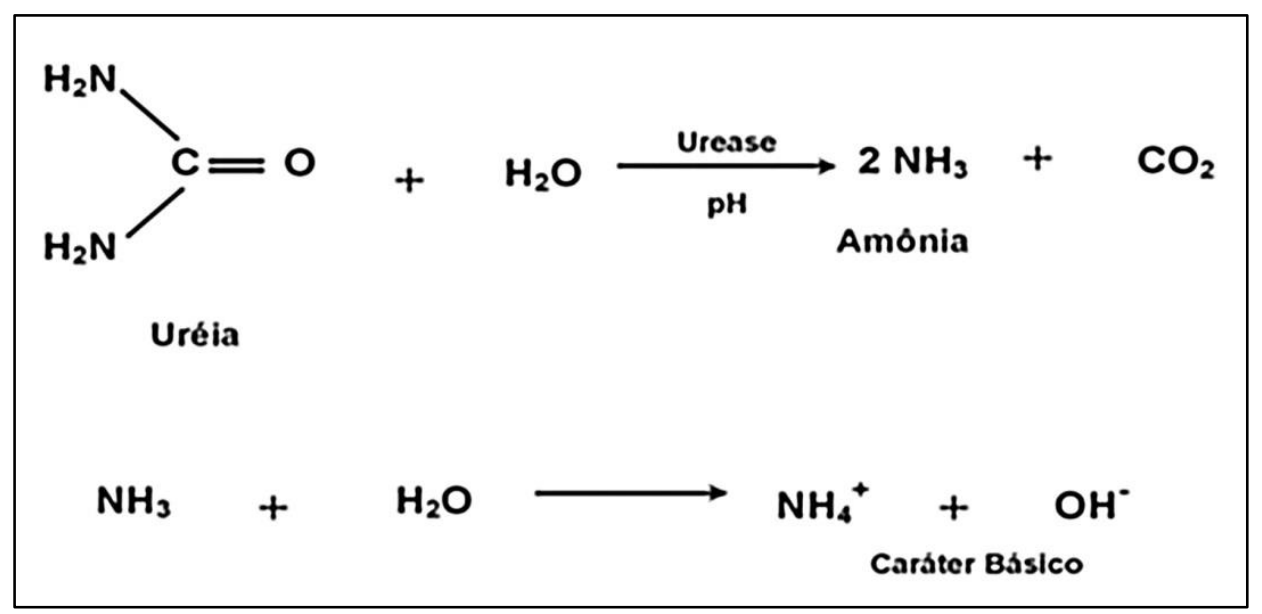

Figura 12: Reação de hidrólise da ureia produzindo amônia (Peruzzo e Canto, 1999).

De acordo com as reações apresentadas no quadro da FIG. 12, a hidrólise da ureia contida na urina produz amônia, sendo esta a substância responsável pelo odor característico. Como observado nas equações de 1 a 4, o Cloro Residual Livre (CRL) decorrente da hidrólise do Dicloroisocianurato de Sódio, é formado pelo Ácido Hipocloroso ( $\mathrm{HClO})$ e Hipoclorito (ClO-).

Sendo assim, numa perspectiva de tratamento de urina com Dicloroisocianurato de Sódio, inevitavelmente ocorrerá a reação do CRL com a fração da amônia derivada da hidrólise da ureia presente na urina.

Se amônia ou compostos amoniacais estão presentes na água, quando adiciona-se um derivado clorado são formados compostos, denominados cloraminas inorgânicas, denominadas de cloro residual combinado (CRC). Estes compostos são resultantes da reação da amônia com o ácido hipocloroso, equações 11 a 16 (Yoon e Jensen, 1995; Meyer, 1994; Tchobanoglous e Burton, 1991; Carswell et al., 1977; Johson e Jensen, 1983).

$$
\begin{aligned}
& \mathrm{NH}^{4+}+\mathrm{HClO} \rightleftharpoons \underset{\text { (monocloramina) }}{\mathrm{NH}_{2} \mathrm{Cl}+\mathrm{H}_{2} \mathrm{O}}+\mathrm{H}^{+} \\
& \mathrm{NH}_{2} \mathrm{Cl}+\mathrm{HClO} \rightleftharpoons \underset{(\text { dicloramina) }}{\mathrm{NHCl}_{2}+\mathrm{H}_{2} \mathrm{O}} \\
& \mathrm{NHCl}_{2}+\mathrm{HClO} \rightleftharpoons \underset{\text { (tricloramina) }}{\mathrm{NCl}_{3}+\mathrm{H}_{2} \mathrm{O}}
\end{aligned}
$$




$$
\begin{aligned}
& \mathrm{NH}_{3}+\mathrm{Cl}_{2} \rightleftharpoons \mathrm{NH}_{2} \mathrm{Cl}+\mathrm{HCl} \\
& \text { (monocloramina) } \\
& \mathrm{NH}_{2} \mathrm{Cl}+\mathrm{Cl}_{2} \rightleftharpoons \underset{\text { (dicloramina) }}{\mathrm{NHCl}_{2}+\mathrm{HCl}} \\
& \mathrm{NHCl}_{2}+2 \mathrm{Cl}_{2} \rightleftharpoons \underset{\text { (tricloramina) }}{\mathrm{NCl}_{3}+2 \mathrm{HCl}}
\end{aligned}
$$

Em valores de $\mathrm{pH}$ superiores a 8,5 prevalece praticamente só monocloramina. Abaixo deste valor, ocorrem dicloramina e tricloroamina, sendo que a dicloramina prevalece quase exclusivamente na faixa de $\mathrm{pH}$ entre 4,5 e 5,5. Em pH abaixo de 4,5 prevalece somente tricloramina.

Define-se cloro residual combinado como sendo o cloro presente na água nas formas de mono, di e tricloramina. Na cloração com cloro combinado, deve-se procurar otimizar a formação de dicloraminas que são melhores desinfetantes. Em uma escala mais ampla de poder de desinfecção, tem-se, em ordem decrescente: dióxido de cloro $\left(\mathrm{ClO}_{2}\right)$, ácido hipocloroso, íon hipoclorito, dicloramina, monocloramina e tricloreto de nitrogênio cujo poder desinfetante é praticamente nulo.

A monocloramina e a dicloramina têm ação bactericida, ao contrário da tricloramina. Em pH 8,5 o $\mathrm{HClO}$ tem pelo menos poder bactericida 25 vezes maior que as cloraminas inorgânicas.

A dicloramina apresenta, em certos casos, ação três vezes maior que a monocloramina. A maior ação bactericida é explicada pela baixa constante de hidrólise da monocloramina formando pouca quantidade de $\mathrm{HClO}$, conforme equação 17 apresentada a seguir (Richter e Azevedo Netto, 1991; Santos Filho, 1985; Carswell et al., 1977).

$$
\mathrm{NH}_{2} \mathrm{Cl}+2 \mathrm{H}_{2} \mathrm{O} \rightleftharpoons \mathrm{NH}_{4} \mathrm{OH}+\mathrm{HClO}
$$

A monocloramina decompõe-se na presença de excesso de cloro segundo a reação: 


$$
2 \mathrm{NH}_{2} \mathrm{Cl}+\mathrm{HOCl} \leftrightarrow \mathrm{N}_{2}+3 \mathrm{HCl}+\mathrm{H}_{2} \mathrm{O}
$$

Quando existe apenas dicloramina, esta tende a se decompor, formando $\mathrm{HOCl}$, conforme equações 19 e:20.

$$
\begin{aligned}
& 2 \mathrm{NHCl}_{2} \leftrightarrow \mathrm{N}_{2}+2 \mathrm{HCl}+\mathrm{Cl}_{2} \\
& \mathrm{Cl}_{2}+\mathrm{H}_{2} \mathrm{O} \leftrightarrow \mathrm{HOCl}+\mathrm{HCl}
\end{aligned}
$$

Quando existe mono e dicloramina, ocorre também decomposição, havendo tendência de desaparecimento da forma que estiver presente inicialmente em menor quantidade (equações 21).

$$
\mathrm{NH}_{2} \mathrm{Cl}+\mathrm{NHCl}_{2} \leftrightarrow \mathrm{N}_{2}+3 \mathrm{HCl}
$$

Quando existem em solução quantidades apreciáveis de monocloramina, o $\mathrm{NCl}_{3}$ se decompõe, segundo a reação:

$$
\mathrm{NCl}_{3}+\mathrm{H}_{2} \mathrm{O} \leftrightarrow \mathrm{NHCl}_{2}+\mathrm{HCl}
$$

De uma maneira global, pode-se representar a destruição das cloraminas pelo excesso de cloro, através da reação simplificada:

$$
2 \mathrm{NH}_{3}+3 \mathrm{Cl}_{2} \leftrightarrow \mathrm{N}_{2}+6 \mathrm{HCl}
$$

Os fenômenos acima descritos podem ser representados graficamente, conforme a FIG. 13. 


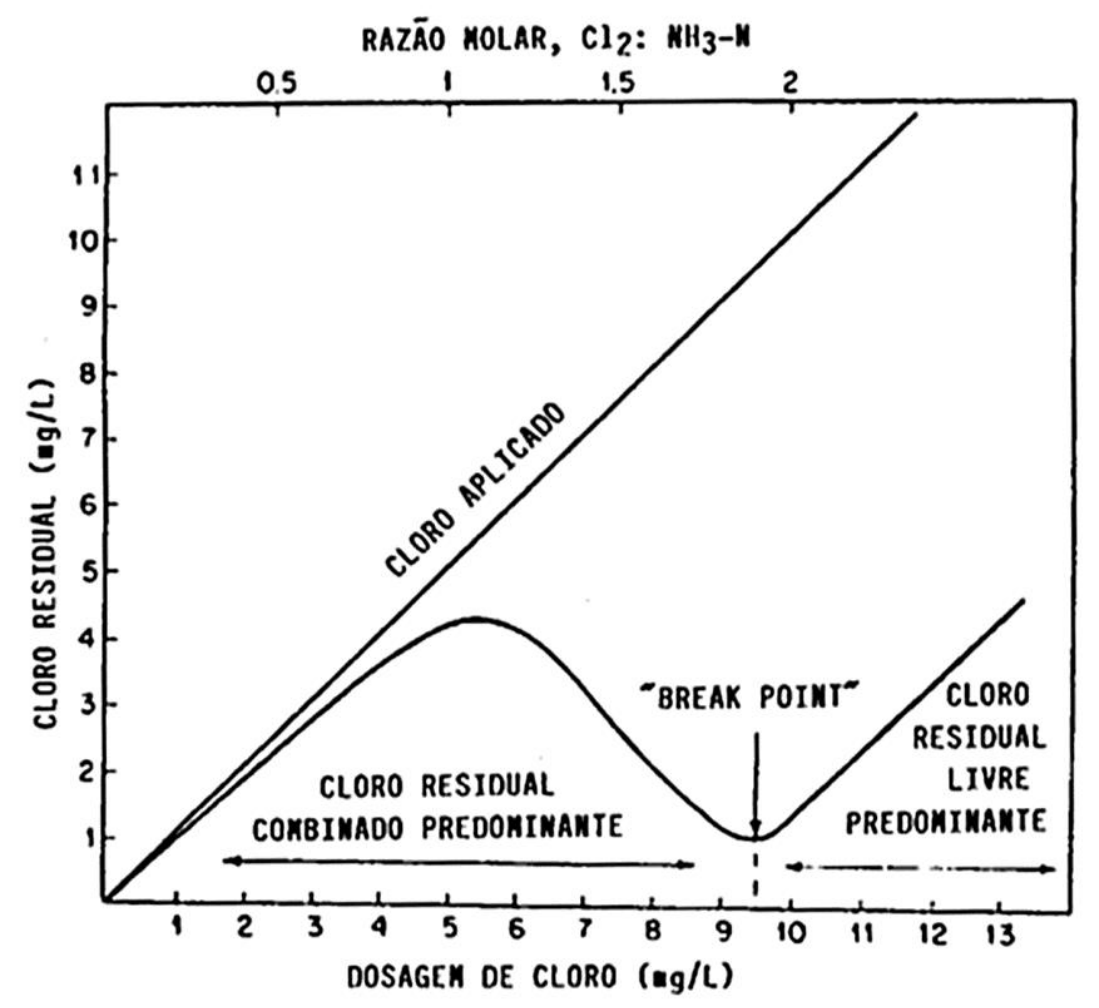

Figura 13: Curva de cloro residual mostrando um "break-point" típico. Conteúdo de nitrogênio amoniacal na água, $1,0 \mathrm{mg} \mathrm{L}^{-1}$ (Cetesb, 1988).

Observando a FIG. 13, verifica-se que o ramo ascendente da curva de cloração indica que as cloraminas estão sendo formadas e o trecho descendente mostra sua destruição, ou seja, a transformação em compostos inertes sob o ponto de vista da desinfecção.

A cloração ao break point ocorre sob condições controladas, adicionando cloro até que a demanda seja satisfeita. O cloro continua a ser adicionado até que os compostos cloro-nitrogenados (cloraminas inorgânicas) também sejam oxidados, pois estes compostos são os responsáveis por odor característico dos derivados clorados.

O ponto em que o cloro adicionado libera somente $\mathrm{HClO}$ e $\mathrm{ClO}^{-}$, com a finalidade somente de desinfecção, é denominado ponto de quebra ou break point (Santos Filho, 1985; Tchobanoglous e Burton, 1991). O cloro reage com outros compostos orgânicos e inorgânicos, em decorrência de sua ação oxidante, como são os casos do ferro, manganês, nitrito e sulfeto. Para este último a reação é:

$$
\mathrm{H}_{2} \mathrm{~S}+4 \mathrm{Cl}_{2}+4 \mathrm{H}_{2} \mathrm{O} \leftrightarrow \mathrm{H}_{2} \mathrm{SO}_{4}+8 \mathrm{HCl}
$$


O cloro oxida também compostos orgânicos, conforme o exemplo:

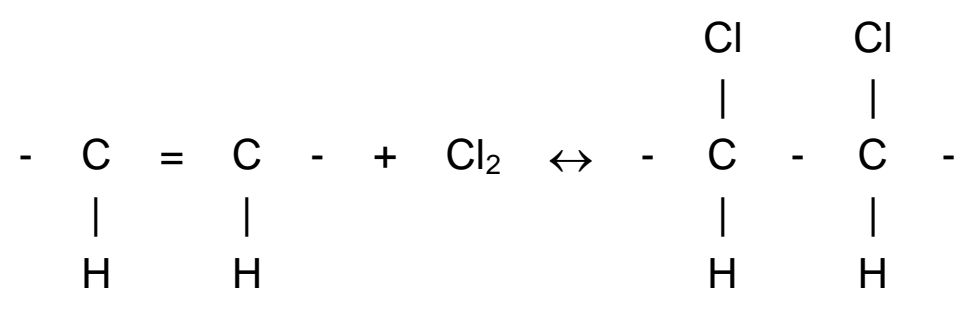

A verificação desses produtos, quanto aos aspectos físico-químicos, devem indicar os possíveis impactos nas estações de tratamento de esgoto, de água e no meio ambiente. Apesar de se operarem em dimensões e condições diferentes, algumas alternativas para a disposição de resíduos gerados pelo tratamento de efluentes sanitários estão descritos nos trabalhos de (Morais, 2009; Morais, 2006).

Considera-se que, no presente trabalho, a massa dos resíduos gerados, volume e concentração de determinadas substâncias no volume da descarga, irão constituir os efluentes líquidos a serem lançados na rede de esgoto.

Os testes em laboratórios, aqui denominados de testes de bancada, têm a finalidade de ajustar os resultados e a eficiência do produto em relação ao tratamento da urina, geração de resíduos e seus impactos além do domicílio. Em função da qualidade dos dados gerados, procurar-se-á a ocorrência de alguma correlação com o usuário deste produto.

\subsection{Testes de Bancada}

Os testes de bancada citados a seguir são de fundamental importância para a adequação da formulação do produto sanitizante, o que permitirá avaliar a eficiência do mesmo frente aos demais testes propostos. Os testes de bancada foram os seguintes:

- Coleta (amostragem) e armazenamento de amostras para análises; 
- Verificações de quais substâncias contidas na fórmula reagem com a amônia (inibindo o odor);

- Verificação das possíveis reações entre as substâncias participantes da formulação básica, em diferentes concentrações;

- Testes de estabilidade da mistura $\mathrm{NaDCC}$ e $\mathrm{NaHCO}_{3}$ para verificação de provável perda de eficiência reacional;

- Realização de testes com substâncias em excesso;

- Testes com algumas essências e corantes;

- Verificação das possíveis interações do NaDCC com todos os demais componentes da fórmula;

- Testes de medição de $\mathrm{pH}$, cor, formação de precipitado e presença de espuma em diferentes intervalos de tempo;

- Medição do tempo de eficiência relativa a uma porção fixa do produto em bacia sanitária contendo urina;

- Medição do volume de água que permanece na bacia sanitária após cada descarga;

Inicialmente todos os testes foram realizados em béqueres de volumes variados, respeitando a proporção de diluição da urina no vaso sanitário. Por avaliação prática observou-se que, em média, um indivíduo normal expele aproximadamente $300 \mathrm{~mL}$ a cada micção na primeira urina do dia.

Considerou-se neste trabalho um volume de $400 \mathrm{~mL}$ de urina por miç̧ão. Levando em conta que o volume de água estacionária nas bacias comuns que é de 1,6L, tem-se uma proporção de $1200 \mathrm{~mL}$ de água e $400 \mathrm{~mL}$ de urina em cada situação analisada.

Os ajustes de concentração de cada componente nas fórmulas testadas levaram em conta uma massa final de produto entre 0,6 e 1,0 g. Portanto a massa a ser adicionada no vaso sanitário para tratamento da urina estará nessa faixa em cada teste. 


\subsection{Testes sensoriais}

As análises sensoriais com consumidores voluntários visam testar o conceito do produto por meio da técnica Mapa de Percepção, que avalia principalmente os odores e aspecto referentes à ação do produto.

Mapas de Percepção são representações gráficas do posicionamento de produtos em relação ao menor número de dimensões consideradas essenciais, pelos consumidores, para julgar e perceber um tipo de produto. Esse tipo de avaliação facilita a identificação de valores, atitudes e opiniões da população ou grupo do qual se estuda (Dolan, 1993).

Eventualmente, pode-se também identificar necessidades ou oportunidades de ação, reação, intervenção, criação e alteração de hábitos. A construção do Mapa de Percepção é precedida por pesquisas qualitativas e quantitativas.

As pesquisas qualitativas são utilizadas para buscar as necessidades dos clientes mesmo que esses clientes não as "conheçam" explicitamente, ou seja, necessidades poderão surgir ou ser identificadas a partir da apresentação de ideias.

Já a pesquisa quantitativa pode ser feita por meio de questionário, com um determinado público para obtenção de informações sobre: 1) a importância de cada atributo; 2) a avaliação/percepção de cada atributo por forma e 3) a preferência geral do produto. Com estes dados pode-se construir o Mapa de Percepção.

Os testes sensoriais avaliam as impressões dos usuários sobre os efeitos do produto adicionado diretamente ao vaso sanitário. Parâmetros como cor, odor, formação e espumas, turvação do meio e geração de precipitado são quesitos importantes nesta avaliação.

Como exemplo prático deste procedimento escolheram-se 10 (dez) famílias, a princípio sem uma composição ou características pré-definidas e que consumiram o produto pelo menos uma vez por dia. Os participantes assinaram 
um termo de ciência e concordância para participação na pesquisa cujo modelo encontra-se no Apêndice 1.

Cada família foi orientada a realizar o teste apenas uma vez ao dia com o produto disponibilizado em pequenos saquinhos plásticos com sistema de fechamento hermético tipo "zip". As instruções fornecidas para os participantes foram as seguintes:

1) Após a micção favor não acionar a válvula de descarga;

2) Abrir o saquinho plástico com o produto e adicionar todo o conteúdo diretamente no vaso sanitário;

3) Observar durante 2 minutos a ação do produto;

4) Retirar uma ficha de avaliação fixada na parede e registrar as observações solicitadas;

O aspecto geral apresentado leva em conta a cor final da solução no interior da bacia sanitária, o odor no ambiente (não característico de urina), formação de espuma, turvação do meio e formação de sólidos no fundo do vaso.

Essas características são importantes para direcionar a opinião dos entrevistados que atribuem uma nota para cada um desses efeitos em escalas diferentes. Por exemplo, para o efeito cor tem-se 5 escalas; entre 0 e 3 (péssimo), entre 3 e 5 (ruim), entre 5 e 7 (Bom), entre 7 e 9 (Muito Bom) e entre 9 e 10 (Ótimo).

O veredito final dos entrevistados será capaz de dar resposta à pergunta final da ficha de avaliação: Você usaria este produto em sua casa? Desta maneira é possível dimensionar o grau de aceitação do produto para a finalidade de substituição da descarga e consequente economia de água.

Estima-se, com base nas dimensões das bacias comerciais, que o volume de água retido ou de residência nas bacias seja de aproximadamente 1,6 L. A FIG. 14 demonstra as dimensões das bacias sanitárias comuns. Esse volume médio deverá ser considerado nos cálculos das quantidades e consequentemente, das concentrações das substâncias componentes do produto. 
As proporções estequiométricas dificilmente são alcançadas em condições reais. Porém, nos testes de laboratório, essas quantidades deverão ser consideradas para que o ajuste do processo em estudo tenha uma referência tanto para as proporções desfavoráveis quanto para as proporções favoráveis.

O estabelecimento dessas condições é importante para que não haja desperdício de material ou mesmo de uso excessivo com potencial elevação desnecessária do risco e para que a falta do princípio ativo não induza a conclusões negativas quanto à eficácia deste produto proposto.

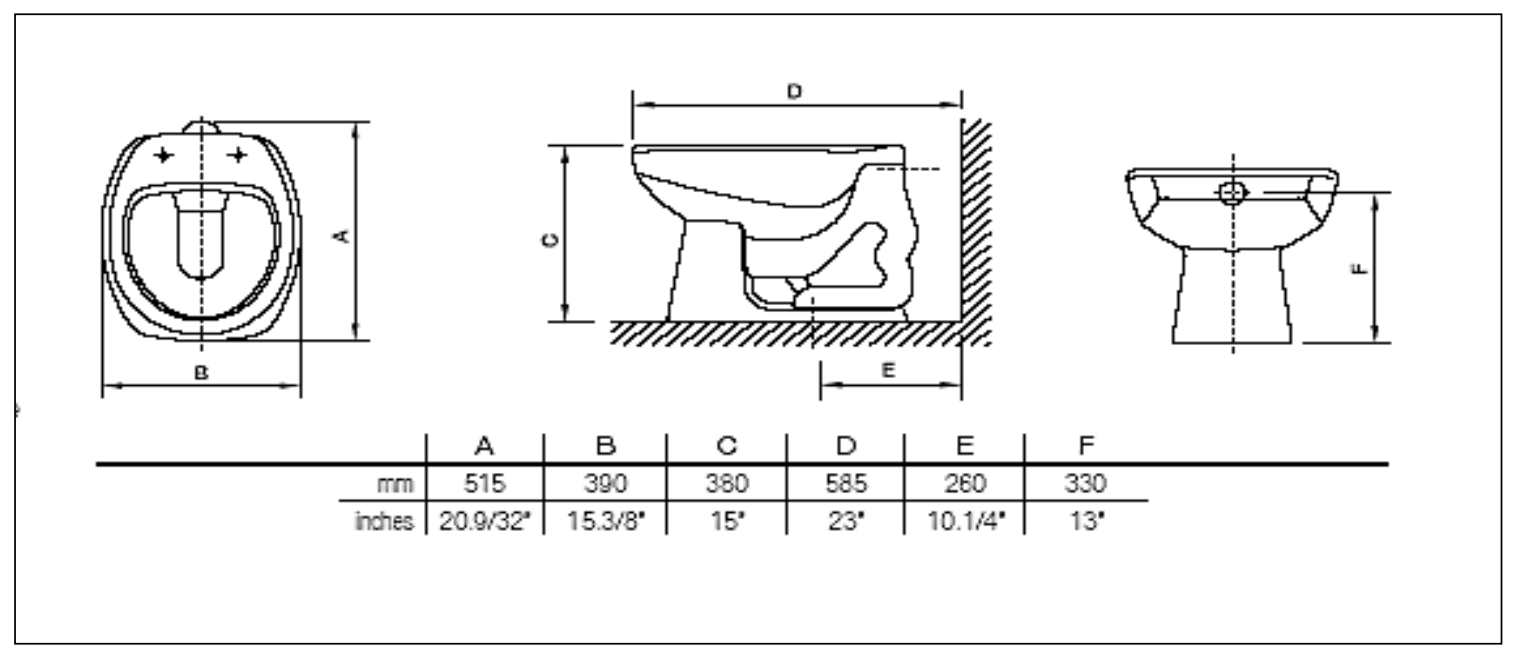

Figura 14: Dimensões das bacias sanitárias comuns. (Deca, 2012).

\subsection{Tratamento estatístico dos dados}

O tratamento estatístico foi aplicado em função do processo e da etapa do trabalho. Em linhas gerais, o desenvolvimento do trabalho consistiu em:

1) Utilizar o NaDCC (Dicloro isocianurato de sódio) como "princípio ativo";

2) Formular uma mistura com diferentes componentes secundários associados aos NaDCC, baseando-se nos testes de bancada realizados;

3) Aplicá-lo inicialmente em formato de pó;

4) Avaliar a eficiência do produto em relação aos parâmetros mais significativos, tais como, aspecto geral (cor, odor, formação de espuma, presença de precipitado), resultados físico-químicos, orgânicos e microbiológicos; 
5) Estudar o comportamento do "princípio ativo" quanto à sua função necessária, ou seja, eliminar ou minimizar os aspectos repulsivos da urina no vaso sanitário;

6) Avaliar a aceitação da pastilha em uma população controlada.

Dessa forma, nas quatro primeiras etapas, uma ferramenta estatística muito interessante a ser aplicada é o Planejamento Fatorial de Experimentos (Chopra, Patil, Motwani, 2007; Box et al, 2005; Neto, Scarmínio, Bruns, 2010) para otimizar o desempenho do produto. Essa ferramenta permite melhorar o conhecimento do processo, estabelecer as condições otimizadas de trabalho e definir os limites seguros (limites que permitem que o processo seja conduzido obtendo-se os mesmos resultados ou resultados compatíveis - Robustez) para os parâmetros estudados.

A partir de uma avaliação futura, será considerado um estudo englobando todas as etapas do processo ou, se for necessário, dividir o processo em subprocessos ou etapas e aplicar essa ferramenta nesses segmentos.

Algumas variações dessas ferramentas multivariadas são utilizadas em estudos semelhantes ao deste projeto (Shin, 2011; Noriega e col., 2008; Martinello e col., 2006; Furlanetto e col., 2005; Naes e col., 1998).

Essa ferramenta estatística é baseada na variação simultânea de múltiplos parâmetros do processo. Para o presente estudo pode-se elencar como exemplo os seguintes parâmetros:

- Teor de NaDCC;

- Teor de Bicarbonato de Sódio;

- Agente Secante;

- Essência;

- Corante;

- Antiespumante;

- Massa do produto aplicado;

- Volume de água no Vaso Sanitário;

- Volume geral de urina;

- Concentração de ureia. 
Esse tratamento estatístico se distingue significativamente de um estudo de variação de um parâmetro de cada vez. A análise dos dados gerados é facilitada, permitindo também, que se verifique a existência de influências por associação entre os parâmetros estudados. A princípio o número de parâmetros a ser estudado não é limitado.

Porém, por bom senso, e pelo conhecimento prévio do processo como um todo, já se considera estudar a influência de mais de 10 parâmetros experimentais. Essa ferramenta pode ser aplicada mais de uma vez em sequência, considerando-se tanto os fundamentos das ferramentas estatísticas multivariadas quanto ao ciclo do PDCA (do inglês: Plan (planejar), Do (realizar), Check (avaliar) e Action (agir ou corrigir).

Por exemplo, quando se tem 7 parâmetros para serem estudados, consegue-se realizar a variação simultânea de todos eles e combiná-los num conjunto de 8 experimentos.

Outra possibilidade, trabalhosa, mas interessante, é a utilização dos gráficos de superfície de resposta para otimizar o processo. Porém, nesse caso trabalha-se com um número menor de parâmetros, normalmente, 2 ou 3 somente.

Essa ferramenta poderia ser utilizada em situações muito específicas do trabalho, uma vez que, como já e sabido, não será possível controlar em limites rígidos as condições experimentais durante o desenvolvimento do processo. Os gráficos de superfície de resposta permitem que obtenha uma direção a ser seguida e uma taxa de progressão dos parâmetros até uma condição otimizada. 


\section{RESULTADOS E DISCUSSÃO}

\subsection{Caracterização geral das amostras a serem tratadas}

A solução de urina que permanece no vaso sanitário após a micção é o objeto de estudo deste trabalho, portanto se faz necessário conhecer algumas de suas características físicas e químicas.

Os testes da TAB. 10 foram realizados no laboratório da empresa FOCO AMBIENTAL Ltda. Apenas os parâmetros Cor e DQO foram realizados em laboratório externo (Acqualab Ltda - Jundiaí).

Para conhecimento de uma possível diferença nos valores dos testes, solicitaram-se amostras (primeira urina do dia) de 4 indivíduos saudáveis e de faixas etárias diferentes. Os voluntários escolhidos afirmaram não fazerem uso de medicamentos e a mulher não consome produto anticoncepcional. $O$ volume médio de micção para esse público foi de $300 \mathrm{~mL}$.

Tabela 10: Resultados das análises da solução de urina diluída.

\begin{tabular}{|c|c|c|c|c|}
\hline \multirow[b]{2}{*}{ Parâmetro } & \multicolumn{4}{|c|}{ Análises gerais da urina humana diluída (4 vezes) } \\
\hline & Homem & Mulher & Criança & Idoso \\
\hline $\mathrm{pH}$ & 6,4 & 6,6 & 6,8 & 6,1 \\
\hline Cor (mg/L Pt/Co) & 850 & 750 & 820 & 910 \\
\hline Densidade (g/L) & 1,002 & 1,000 & 1,002 & 1,004 \\
\hline Amônia (mg/L NH ${ }_{3}$ ) & 272 & 184 & 197 & 296 \\
\hline N-Amoniacal (mg/L N) & 223 & 151 & 162 & 243 \\
\hline Turbidez (UNT) & 45,5 & 22,5 & 35 & 52 \\
\hline $\mathrm{DQO}\left(\mathrm{mg} / \mathrm{L} \mathrm{O} \mathrm{O}_{2}\right)$ & 1795 & 998 & 1800 & 2105 \\
\hline Aspecto Visual & Límpido & Límpido & Límpido & Límpido \\
\hline
\end{tabular}

Os resultados acima demonstram não haver muita discrepância em relação à faixa etária. As diferenças existentes possivelmente são decorrentes de hábitos alimentares ou do próprio metabolismo de cada indivíduo. 


\subsection{Avaliação prévia dos efeitos do NaDCC em Urina Diluída}

Inicialmente foram realizados alguns testes com pequenas quantidades de produto Dicloroisocianurato de Sódio, NaDCC, em béqueres. A TAB. 11 apresenta os resultados dos 12 experimentos, com destaque à amostra ํㅡ 3 , que resultou na melhor combinação de valores de cor, $\mathrm{pH}$, odor, espuma e presença de sólidos.

O produto foi macerado em almofariz e as massas foram adicionadas em um volume fixo de $10 \mathrm{~mL}$ de solução 1:3 de urina e água.

Tabela 11: Resultados dos testes para avaliação do comportamento do NaDCC em solução de urina.

\begin{tabular}{cccccccc}
\hline Amostra & $\begin{array}{c}\text { Massa } \\
\mathbf{( g )}\end{array}$ & $\mathbf{p H}$ & $\begin{array}{c}\text { Turbidez } \\
\text { (NTU) }\end{array}$ & $\begin{array}{c}\text { Cor } \\
\text { (Pt/Co) }\end{array}$ & $\begin{array}{c}\text { Odor de } \\
\text { Urina } \\
\text { (Sensorial) * }\end{array}$ & Espuma * & $\begin{array}{c}\text { Presença } \\
\text { de Sólido } \\
\text { no fundo* }\end{array}$ \\
\hline Controle & - & 6,00 & 6 & 500 & 5 & 1 & 1 \\
$\mathbf{1}$ & 0,010 & 6,30 & 11,3 & 400 & 4 & 1 & 1 \\
$\mathbf{2}$ & 0,020 & 6,29 & 15,3 & 300 & 3 & 2 & 1 \\
$\mathbf{3}$ & 0,050 & 6,18 & 17,0 & 180 & 1 & 2 & 1 \\
$\mathbf{4}$ & 0,080 & 6,15 & 61,2 & 200 & 1 & 2 & 2 \\
$\mathbf{5}$ & 0,100 & 6,13 & 76,8 & 300 & 1 & 3 & 2 \\
$\mathbf{6}$ & 0,150 & 6,10 & 100 & 300 & 1 & 3 & 2 \\
$\mathbf{7}$ & 0,200 & 6.04 & 119 & 350 & 1 & 3 & 2 \\
$\mathbf{8}$ & 0,250 & 6,08 & 135 & 350 & 1 & 3 & 3 \\
$\mathbf{9}$ & 0,300 & 6,08 & 124 & 400 & 1 & 3 & 4 \\
$\mathbf{1 0}$ & 0,400 & 6,04 & 171 & 400 & 1 & 4 & 4 \\
$\mathbf{1 1}$ & 0,500 & 5,94 & 223 & 400 & 1 & 5 & 5 \\
$\mathbf{1 2}$ & 0,800 & 5,67 & 295 & 500 & 1 & 5 & 5 \\
\hline
\end{tabular}

* a metodologia e escala para medida destes parâmetros é explicada abaixo.

Os parâmetros sensoriais (odor, espuma e presença de sólidos) foram avaliados por 10 observadores e os resultados são a média desses valores atribuídos.

\subsubsection{Teste de Cor}

Para o item cor utilizou-se uma escala padrão de cor ( $\mathrm{Pt} / \mathrm{Co}$ ) baseada na norma ASTM D 1209, FIG. 15, feita a partir das diluições de uma solução padrão no 500 Platina/Cobalto. Para preparo dessa solução dissolve-se $1,245 \mathrm{~g}$ de Hexacloroplatinato de Potássio p.a. e $1,0 \mathrm{~g}$ de Cloreto de Cobalto p.a em 
béqueres de $200 \mathrm{~mL}$ separados. Após a dissolução completa, juntar as duas soluções em outro béquer $600 \mathrm{~mL}$ e adicionar $100 \mathrm{~mL}$ de Ácido Clorídrico concentrado. Transferir para balão volumétrico de $1000 \mathrm{~mL}$ e completar o volume com água deionizada.

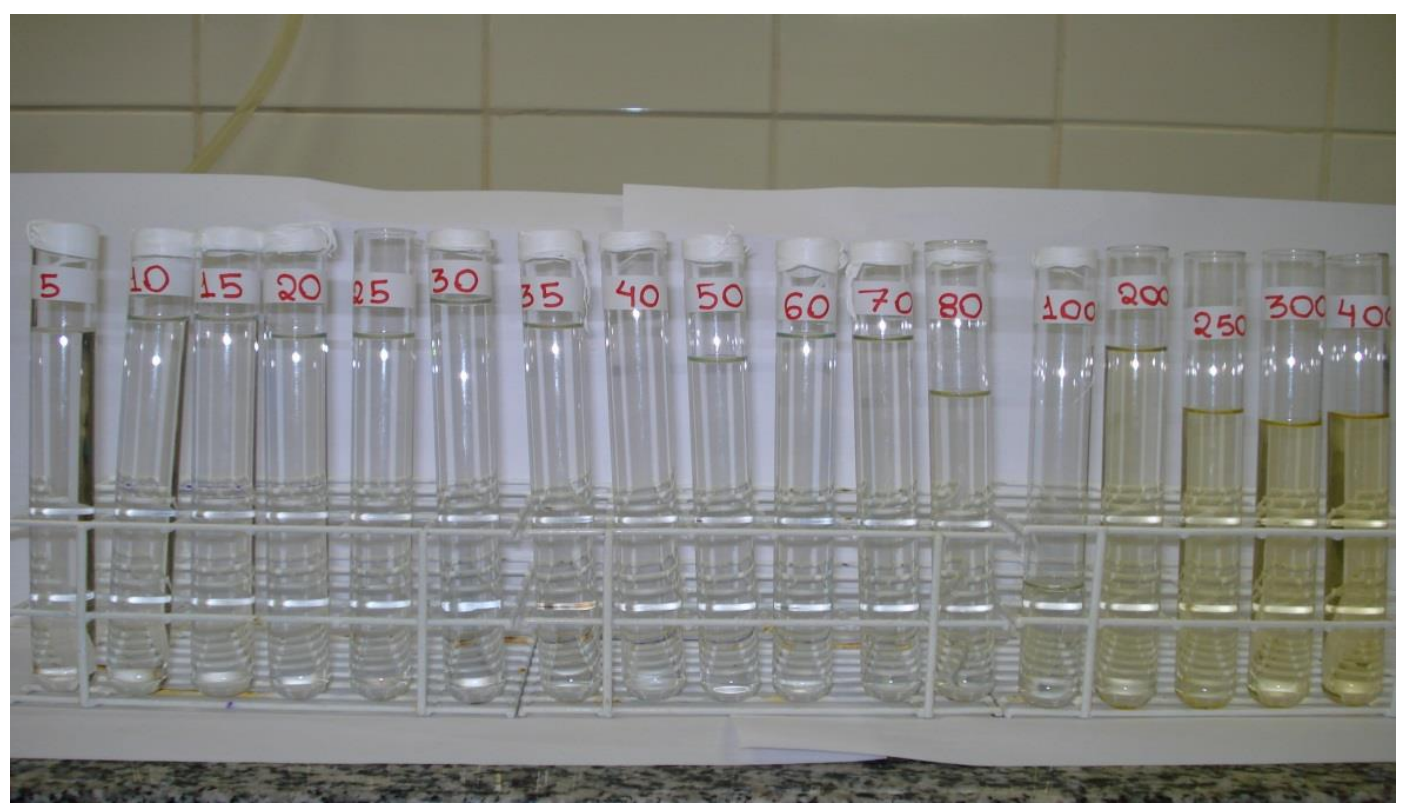

Figura 15: Escala de padrão comparativo de cor (Pt/Co).

A FIG. 16 demonstra um exemplo do processo de medida da leitura comparativa de cor com uso do padrão Pt/Co.

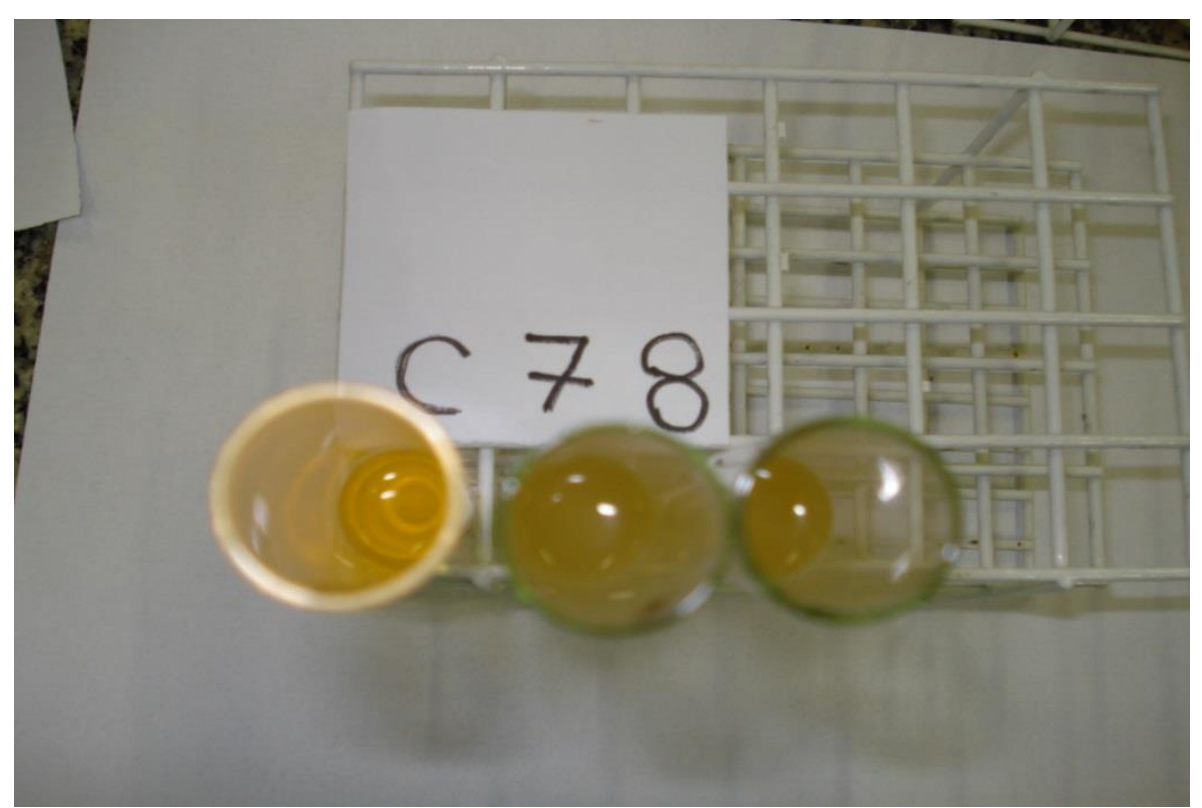

Figura 16: Exemplo do processo de leitura de cor com padrão (Pt/Co). 


\subsubsection{Teste de Espuma}

Para a avaliação da formação de espumas após adição do produto aos béqueres contendo urina, foi criada uma escala com valores entre 1 e 5 . Os avaliadores atribuíram notas de acordo com a observação referente ao efeito mencionado em cada valor.

Formação de Espumas:

1- Ausente

2- baixíssima presença

3- baixa presença

4- boa presença

5- Grande presença

A FIG. 17, ilustra um exemplo de nível 5 de espuma (béqueres 11 e 12 com 0,5 e 0,8 de NaDCC respectivamente).

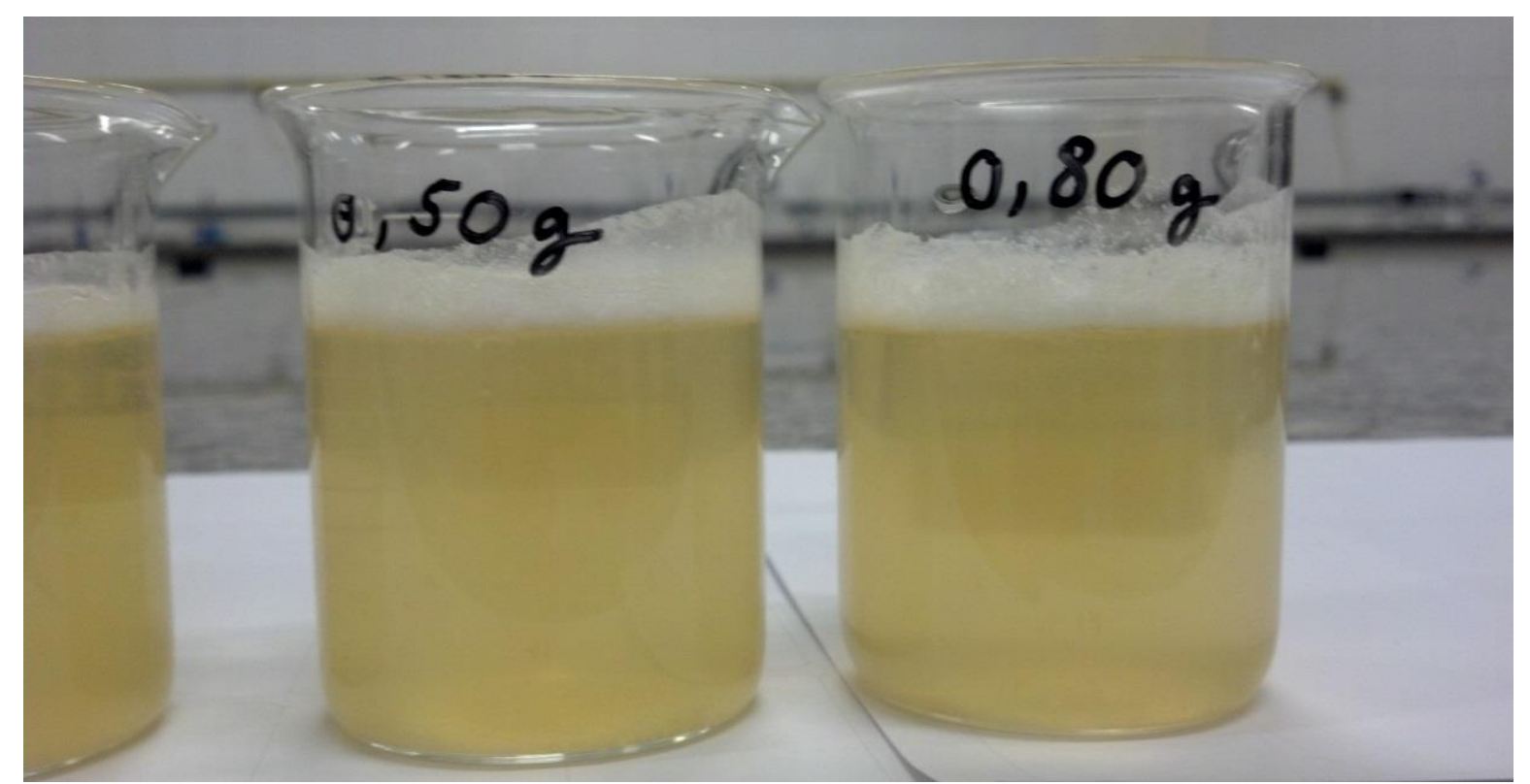

Figura 17: Exemplo do processo de medida do nível de espuma nos béqueres.

\subsubsection{Teste de presença de sólidos}

Para este teste também foi criada uma escala entre 1 e 5 que possibilitou aos avaliadores mensurar o grau de presença de sólidos após a adição do produto à solução de urina. 
Presença de sólidos:
1- Ausente
2- baixíssima presença
3- baixa presença
4- boa presença
5- Grande presença

O produto foi macerado em almofariz e as massas foram adicionadas em um volume fixo de $10 \mathrm{~mL}$ de solução $1: 3$ de urina e água. As FIG. 18 a 20 ilustram a sequência dos béqueres desde a amostra controle até a adição de $0,80 \mathrm{~g}$ de NaDCC. As FIG. 19 e 20 correspondem a fotografias parciais dessas sequências em função da limitação do ângulo de abertura da máquina fotográfica, respectivamente após 2 e 10 minutos da adição. As massas de produto foram adicionadas em formato de pó macerado em almofariz.

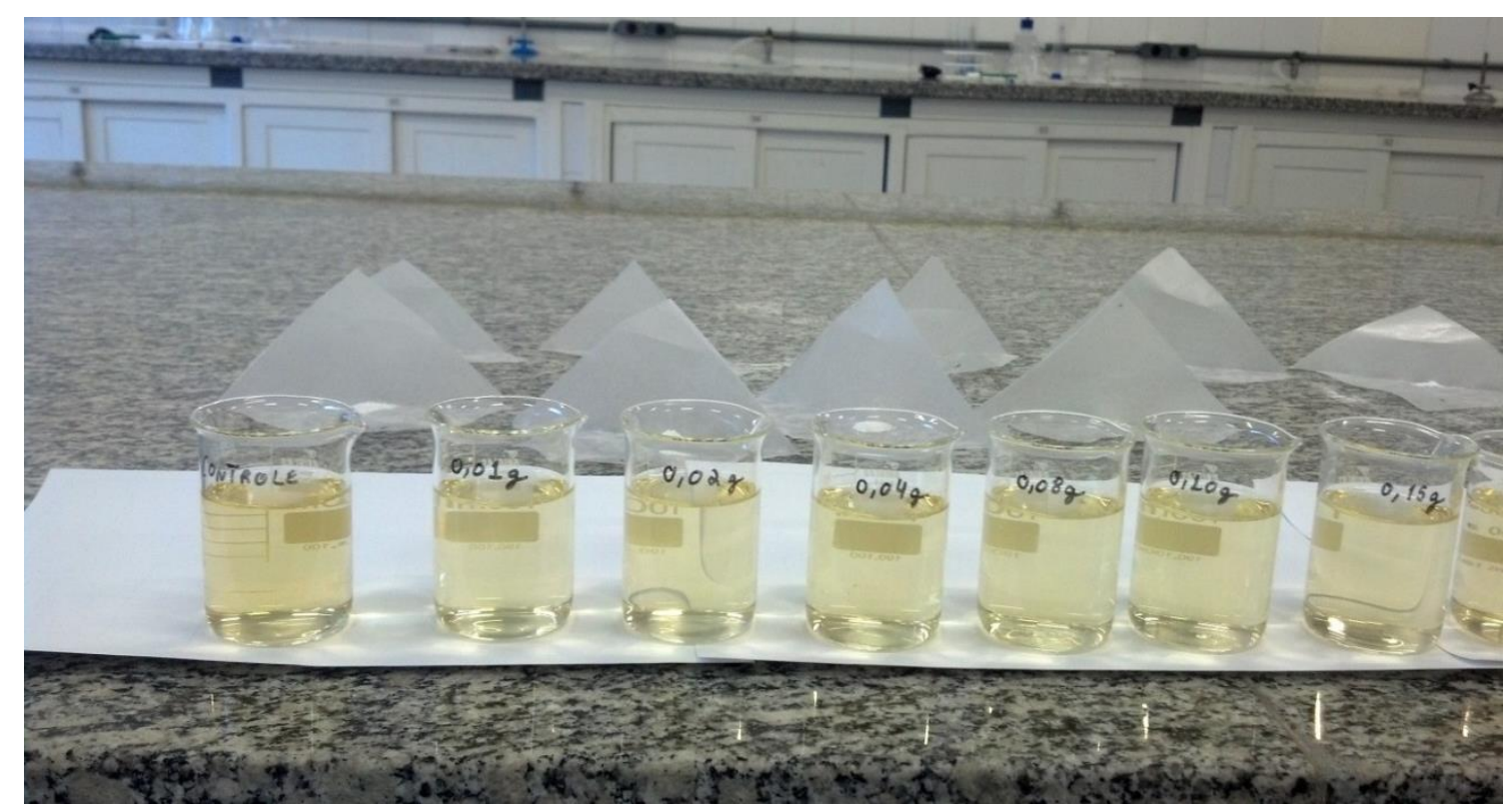

Figura 18: Béqueres contendo urina diluída em água (proporção 1:3) antes da adição das massas de NaDCC. 


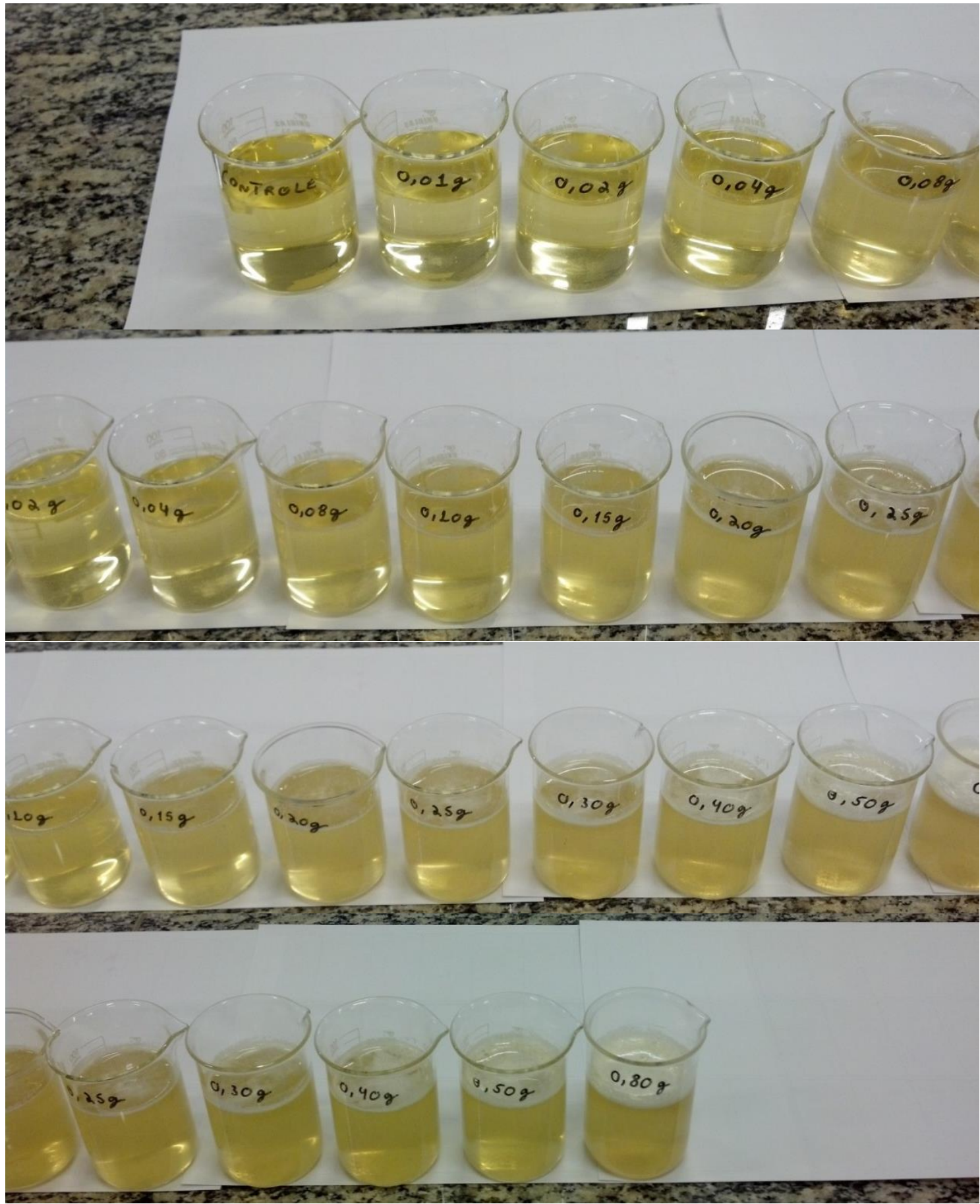

Figura 19: Sequência dos béqueres após 2 minutos da adição do produto. 


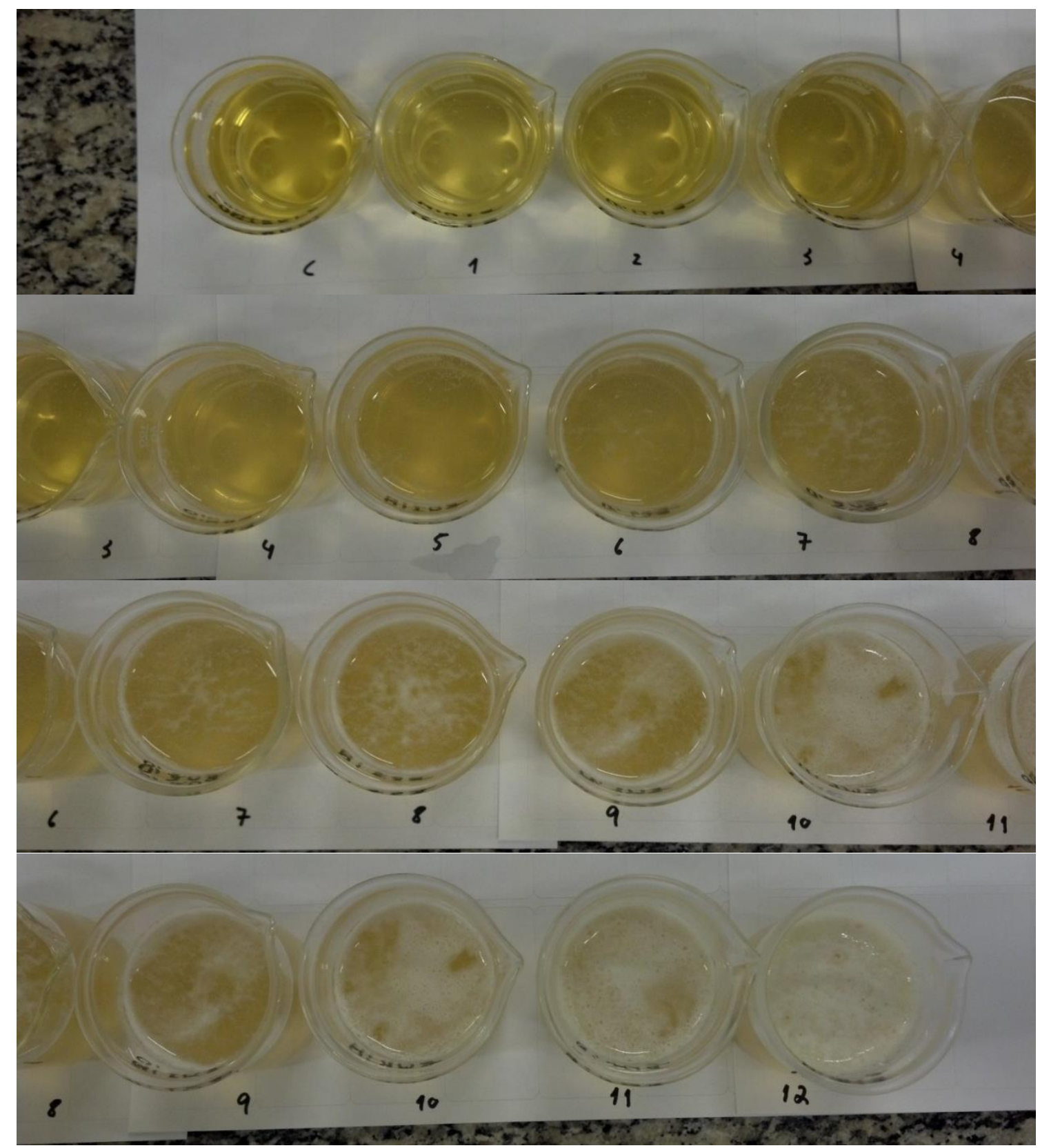

Figura 20: Visão superior dos béqueres após 10 minutos da adição do produto.

Os ajustes de concentração de cada componente nas fórmulas testadas levaram em conta uma massa final de produto entre 0,6 e 1,0g, pois considerou-se o valor do teste 3 o melhor entre os demais avaliados com uma proporção em massa de $0,05 \mathrm{~g}$ em $10 \mathrm{~mL}$ de solução. Desta maneira, relacionando ao volume de $1600 \mathrm{~mL}$ (valor estimado dos vasos sanitários), obtém-se um valor médio de $0,8 \mathrm{~g}$ de produto. 
A FIG. 21 destaca os 12 testes em tubos de ensaio após 20 minutos da adição do produto.

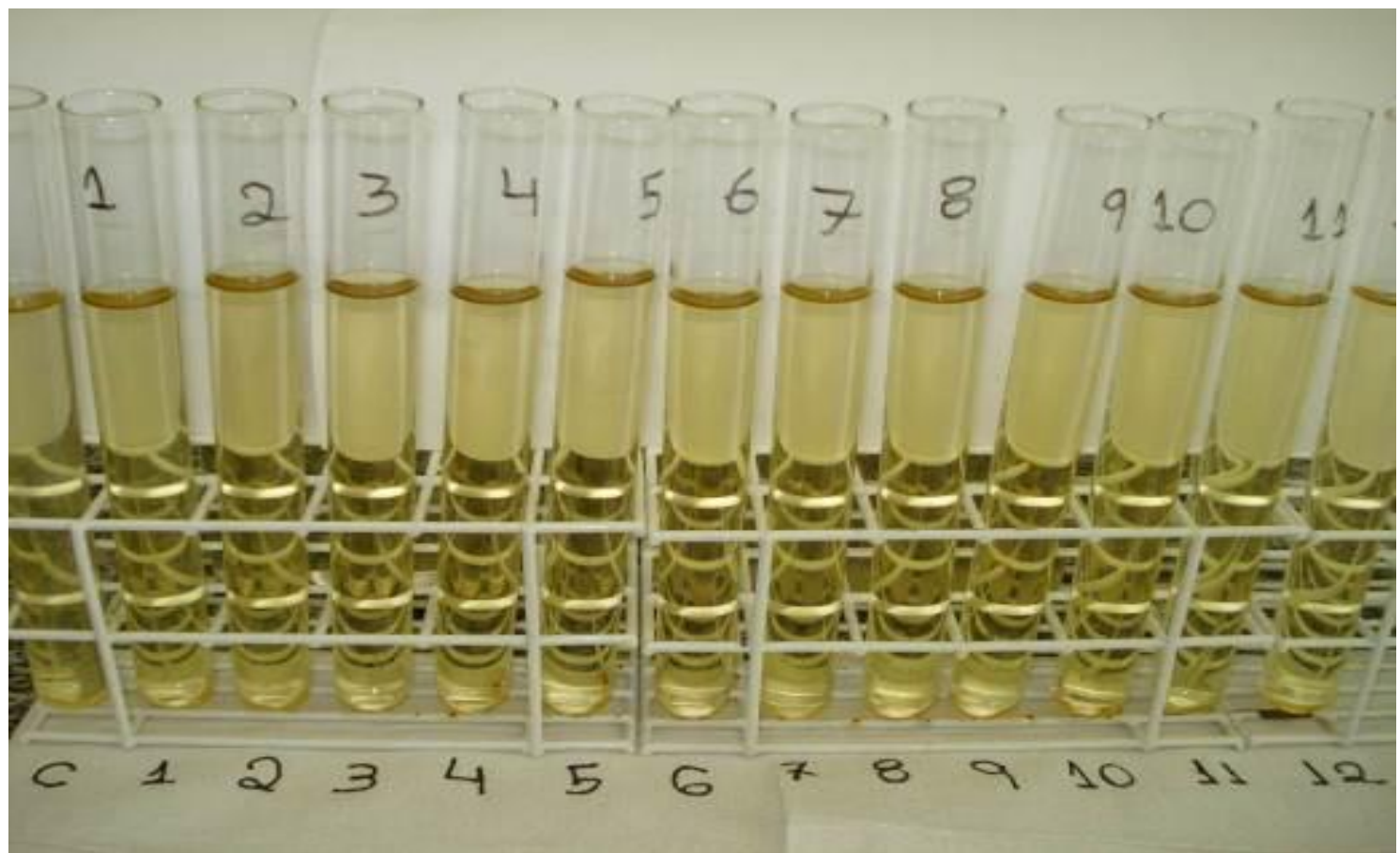

Figura 21: Soluções de urina em tubos de ensaio após 20 minutos da adição do produto.

\subsection{Otimização da formulação - Planejamento Fatorial}

Neste planejamento avaliou-se a importância de cada componente para a eliminação da concentração de amônia na solução. Como já informado, o produto principal é o Dicloroisocianurato de Sódio, NaDCC, porém foram testadas diversas substâncias em associação a este composto, visando uma melhor eficiência do produto final.

Os fatores avaliados nesse planejamento foram escolhidos mediante pesquisa dos principais produtos sanitizantes disponíveis no mercado e da ação/função desejada do produto final.

O teor de amônia da solução é um parâmetro importante nesta avaliação devido ao odor característico conferido à urina e por isso é um resultado inicialmente escolhido como exemplo neste trabalho. Os principais fatores observados neste planejamento são: 
- Teor de NaDCC;

- Teor de Bicarbonato de Sódio;

- Agente Secante;

- Essência;

- Corante;

- Antiespumante;

- Massa do produto aplicado;

Este teste de robustez é igual ao planejamento fatorial de 7 variáveis com 8 experimentos (planejamento fracionário saturado). Para cada uma das 8 combinações tem-se um resultado de determinado teste.

\begin{tabular}{|c|c|c|c|c|c|c|c|c|}
\hline & & & $(-1)$ & $(+1)$ & & & & \\
\hline \multicolumn{3}{|c|}{ Fator } & Nominal & Variação & & & & \\
\hline 1 & \multicolumn{2}{|c|}{ NaDCC, $\mathbf{g}$} & 0,45 & 1 & & & & \\
\hline 2 & \multicolumn{2}{|c|}{$\mathrm{NaHCO}, \mathbf{g}$} & 0 & 0,5 & & & & \\
\hline 3 & \multicolumn{2}{|c|}{ Amido, $\mathbf{g}$} & 0 & 0,5 & & & & \\
\hline 4 & \multicolumn{2}{|c|}{ Essência, g } & 0 & 0,25 & & & & \\
\hline 5 & \multicolumn{2}{|c|}{ Corante, $\mathrm{g}$} & 0,005 & 0,009 & & & & \\
\hline 6 & \multicolumn{2}{|c|}{ Antiespumante, $\mathrm{g}$} & 0 & 0,12 & & & & \\
\hline \multirow[t]{3}{*}{7} & \multicolumn{2}{|c|}{ Massa adição, g } & 0,025 & 0,05 & & & & \\
\hline & \multicolumn{5}{|c|}{ Combinação de cada ensaio } & & & \\
\hline & 1 & 2 & 3 & 4 & 5 & 6 & 7 & 8 \\
\hline 1 & 1 & 1 & 1 & 1 & -1 & -1 & -1 & -1 \\
\hline 2 & 1 & 1 & -1 & -1 & 1 & 1 & -1 & -1 \\
\hline 3 & 1 & -1 & 1 & -1 & 1 & -1 & 1 & -1 \\
\hline 4 & 1 & 1 & -1 & -1 & -1 & -1 & 1 & 1 \\
\hline 5 & 1 & -1 & 1 & -1 & -1 & 1 & -1 & 1 \\
\hline 6 & 1 & -1 & -1 & 1 & 1 & -1 & -1 & 1 \\
\hline 7 & 1 & -1 & -1 & 1 & -1 & 1 & 1 & -1 \\
\hline \multicolumn{9}{|c|}{$\begin{array}{l}\text { Resultado } \\
\text { Média dos } \\
\text { Resultados: }\end{array}$} \\
\hline \multicolumn{9}{|c|}{ Desvio padrão dos Resultados: } \\
\hline
\end{tabular}

A FIG. 22 ilustra os 8 béqueres contento as urinas diluídas na proporção do vaso sanitário, 1:3, urina e água. $\mathrm{Na}$ imagem, os béqueres com 
vidro de relógio já estão com as massas das 8 formulações medidas. Na FIG. 23 observam-se as 8 soluções imediatamente após a adição do produto.

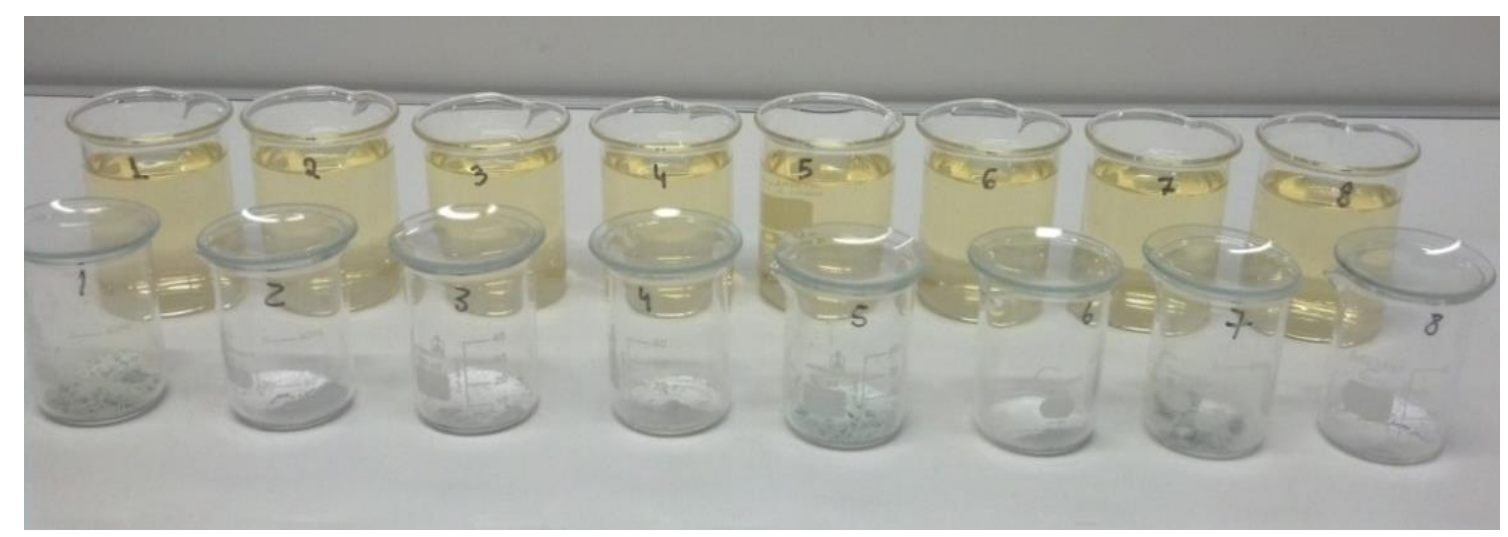

Figura 22: Sequência dos 8 testes e as massas das formulações para adição.

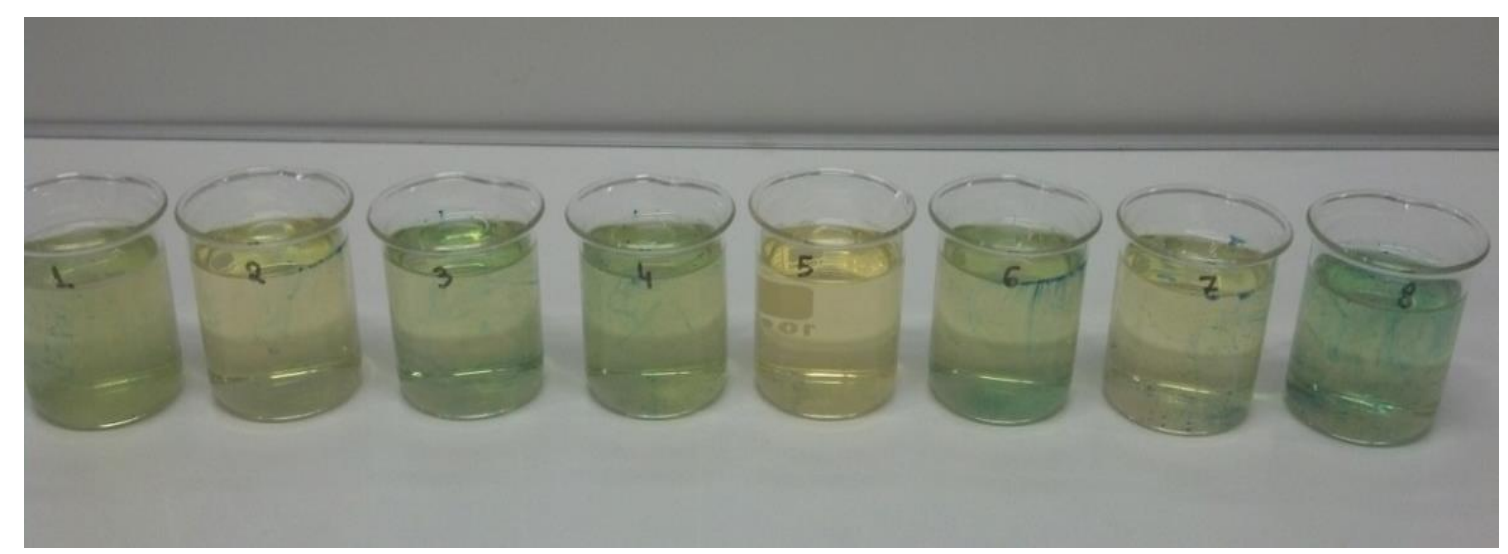

Figura 23: Avaliação imediatamente após a adição das massas.

As massas foram adicionadas simultaneamente e o tempo foi cronometrado. Observou-se uma ligeira efervescência em todos os casos.

Na FIG. 24 observam-se as 8 soluções após 5 minutos da adição do produto. Neste momento já não há qualquer indício de efervescência no meio: 


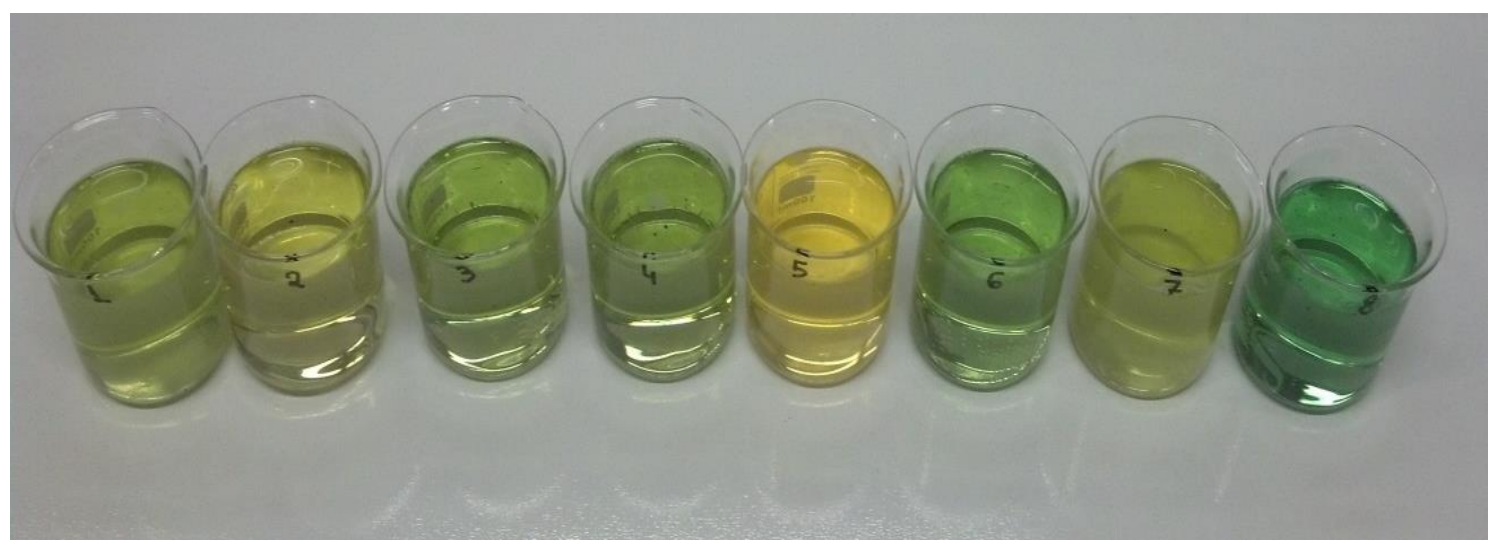

Figura 24: Avaliação após 5 minutos da adição das massas.

Após 10 minutos transferiu-se o conteúdo dos béqueres a tubos Nesler para uma melhor observação, FIG. 25. Um tubo identificado com a letra C referese à urina sem diluição, neste caso chamado de controle.

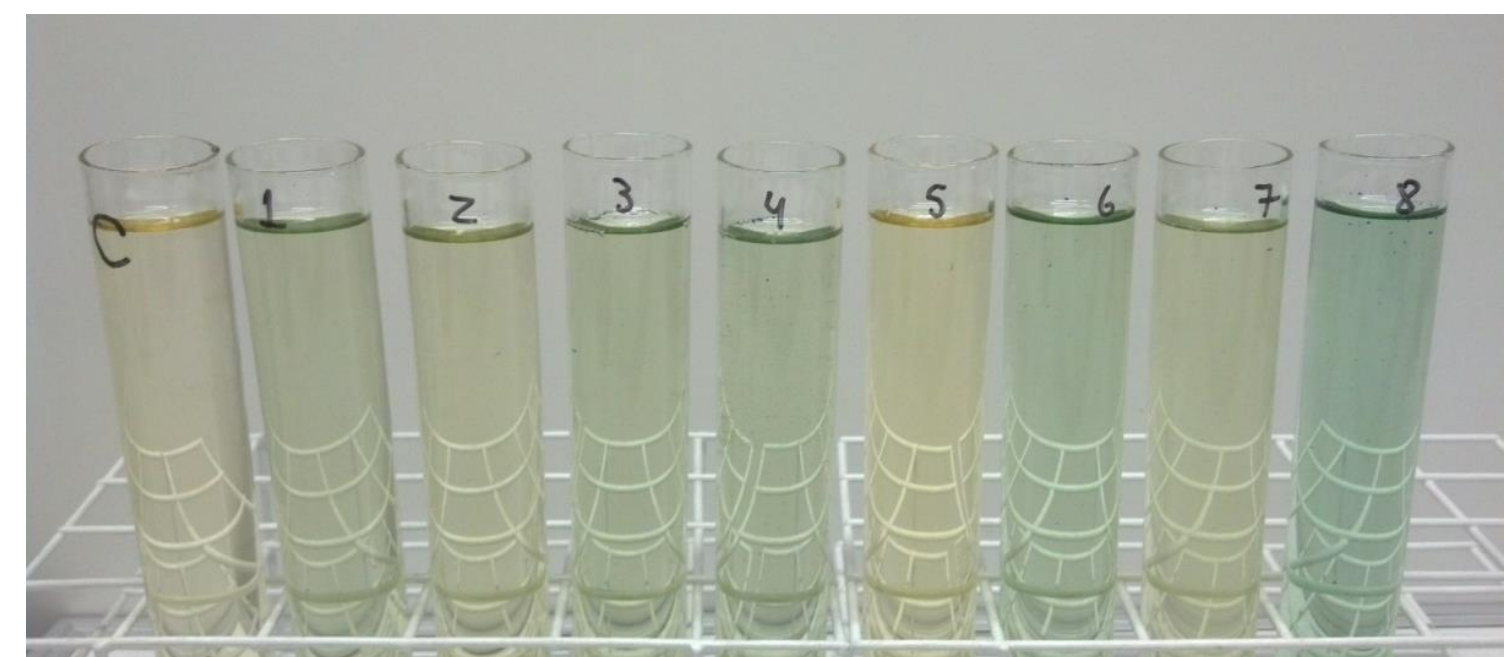

Figura 25: Avaliação em tubos Nesler após 10 minutos da adição das massas.

\subsubsection{Avaliação da concentração de amônia}

No quadro da FIG. 26 são apresentados os resultados do estudo de robustez frente a pequenas variações de sete parâmetros relevantes paraa concentração de amônia. 


\begin{tabular}{|c|c|c|c|c|c|c|c|c|c|c|c|c|}
\hline & & & & & $(-1)$ & $(+1)$ & & & & & & \\
\hline & & ator & & & ominal & Variação & & & & & & \\
\hline 1 & & $\mathrm{NaDC}$ & , g & &, 45 & 1 & & & & & & \\
\hline 2 & & $\mathrm{NaHC}$ & ${ }_{3}, \mathbf{g}$ & & 0 & 0,5 & & & & & & \\
\hline 3 & & Amid & & & 0 & 0,5 & & & & & & \\
\hline 4 & & Essên & ia, $\mathbf{g}$ & & 0 & 0,25 & & & & & & \\
\hline 5 & & Coran & $e, g$ & & 005 & 0,009 & & & & & & \\
\hline 6 & An & iespur & lante, $\mathrm{g}$ & & 0 & 0,12 & & & & & & \\
\hline 7 & & issa ac & ição, $g$ & & 075 & 0,15 & & & & & & \\
\hline & & & & & Coml & binação de & cada el & nsaio & & & & \\
\hline & & 1 & 2 & 3 & 3 & 4 & 5 & & 6 & & 7 & 8 \\
\hline 1 & & 1 & 1 & 1 & 1 & 1 & -1 & & -1 & & -1 & -1 \\
\hline 2 & & 1 & 1 & -1 & -1 & -1 & 1 & & 1 & & -1 & -1 \\
\hline 3 & & 1 & -1 & & 1 & -1 & 1 & & -1 & & 1 & -1 \\
\hline 4 & & 1 & 1 & -1 & -1 & -1 & -1 & & -1 & & 1 & 1 \\
\hline 5 & & 1 & -1 & & 1 & -1 & -1 & & 1 & & -1 & 1 \\
\hline 6 & & 1 & -1 & -1 & -1 & 1 & 1 & & -1 & & -1 & 1 \\
\hline 7 & & 1 & -1 & & -1 & 1 & -1 & & 1 & & 1 & -1 \\
\hline Resultad & & 4,05 & 109,24 & 114 & 4,03 & 119,53 & 123,50 & & 111,10 & & 122,07 & 121,29 \\
\hline Média do & s Res & Itados & & & 17 & & & & & & & \\
\hline Desvio pe & adrão & los Res & ultados & 5 & 5 & & & & & & & \\
\hline $\begin{array}{l}\text { Teste para v } \\
\text { Referência: } \mathrm{V}\end{array}$ & $\begin{array}{l}\text { verificaç } \\
\text { vander He }\end{array}$ & $\begin{array}{l}\text { o de signi } \\
\text { den, e col. }\end{array}$ & $\begin{array}{l}\text { cância dos } \\
\text { f. Pharm. Bio }\end{array}$ & $\begin{array}{l}\text { efeitos } \\
\text { med. Anal }\end{array}$ & $\begin{array}{l}l .24(2001) \\
\text { Os cálculos̀ }\end{array}$ & $\begin{array}{l}723-753 . \\
\text { ș para obtenção dr }\end{array}$ & los valores & de ME e & e SME sã & io basead & ados no algor & ritmo de Dong \\
\hline Fator & Efeitos & $\begin{array}{r}\text { renamento } \\
\text { Efetios }\end{array}$ & $\begin{array}{l}\text { Efeitos Orc } \\
\text { Absolutos }\end{array}$ & $\begin{array}{c}\text { denamentio } \\
\text { Absoluto }\end{array}$ & $\begin{array}{l}\text { Quadrado do } \\
\text { Orden Abs }\end{array}$ & Ordem & & & (Ф) & Rankit & $\begin{array}{c}\text { Orden Éetitos' } \\
\text { Abs }\end{array}$ & \\
\hline 1 & $-5,28$ & $-5,28$ & $5,28^{\prime}$ & $0,33^{\prime}$ & 0,11 & $\quad 10,07143$ & $-1,4652$ & 0 & 0,54 & 0,09 & $9 \quad 0,33$ & $\begin{array}{lll}3,9,973 & 9,43637\end{array}$ \\
\hline 2 & $-4,76$ & $-4,76$ & $4,76^{\prime}$ & $0,38^{\circ}$ & 0,14 & $\begin{array}{l}20,21429 \\
\end{array}$ & $-0,7916$ & 0 & 0,61 & 0,27 & 0,38 & \\
\hline 3 & 3,12 & $-3,47$ & $3,47^{\prime}$ & $3,12^{\prime}$ & 9,75 & $\begin{array}{ll}3 & 0,35714\end{array}$ & $-0,3661$ & 3 & 0,68 & 0,46 & 3,12 & \\
\hline 4 & $-0,38$ & $-0,38$ & $0,38^{\prime \prime}$ & $3,47^{\circ}$ & 12,02 & $\begin{array}{ll}4 & 0,5\end{array}$ & & 3 & 0,75 & 0,67 & 3,47 & \\
\hline 5 & $-3,47$ & $-0,33$ & $0,33^{\prime \prime}$ & $4,76^{\prime \prime}$ & 22,63 & 50,64286 & 0,36611 & 5 & 0,82 & 0,92 & 4,76 & \\
\hline 6 & 5,48 & 3,12 & $3,12^{\prime \prime}$ & $5,28^{\circ}$, & 27,85 & $\begin{array}{ll}6 & 0,78571\end{array}$ & $0,79164 \backslash$ & 5 & 0,89 & 1,24 & 5,28 & \\
\hline 7 & $-0,33$ & 5,48 & $5,48^{\prime}$ & $5,48^{\circ}$ & 30,06 & $\begin{array}{ll}7 & 0,92857\end{array}$ & 1,46523 & | 5 & 0,96 & 1,80 & 5,48 & $\begin{array}{lll}5,973 & 9,43637\end{array}$ \\
\hline média & $-0,80$ & & soma & & 102,57 & & $\begin{array}{r}\text { mediana } \\
s_{0}\end{array}$ & $\begin{array}{r}3,4675 \\
5,20\end{array}$ & $1^{m}$ & & IC, \% & 95 \\
\hline Erro Padrão " & 3,83 & & & & & & $\begin{array}{c}2,5^{*} s_{0} \\
s_{1}\end{array}$ & $\mid$\begin{tabular}{|l|}
2,52579 \\
13,00
\end{tabular} & $\begin{array}{l}\text { ME' } \\
\text { SME' }\end{array}$ & $\begin{array}{l}5,97253 \\
9,43637\end{array}$ & & $\begin{array}{r}0,05 \\
0,007\end{array}$ \\
\hline
\end{tabular}

Figura 26: Teste para verificação da significância dos efeitos para os valores da resposta da medição da concentração de amônia. 


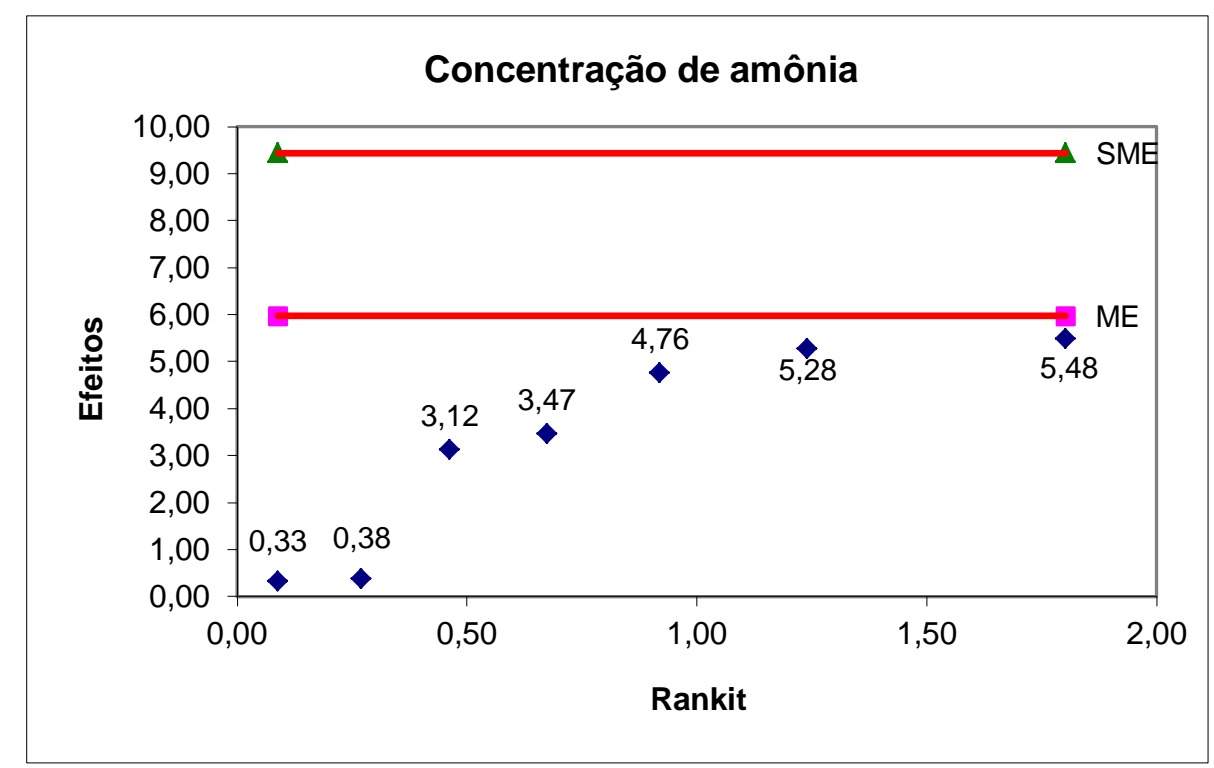

Figura 27: Gráfico de Rankit para concentração de amônia.

Os parâmetros "NaDCC" e "Antiespumante" são os mais sensíveis ou significativos do processo e as condições estudadas não estão otimizadas. Ao aumentar a massa de $\mathrm{NaDCC}$ de 0,45 para $1,0 \mathrm{~g}$, a concentração de amônia diminui e a adição de antiespumante contribui para a (não) diminuição da concentração de amônia. Os resultados dos testes de caracterização na TAB. 9 comprovam essa interferência do antiespumante sobre a diminuição da concentração da amônia.

Todos os demais pontos estão abaixo desse limite; o fator 1 referente ao NaDCC é o que apresenta menor efeito $(-5,28)$, então, é o fator que mais diminui a concentração de amônio; Assim, o $\mathrm{NaHCO}_{3}$ também é um fator que contribui para diminuir a concentração de amônio; O amido também está contribuindo para a não diminuição da concentração de amônio;

\subsubsection{Avaliação da alteração do pH}

Utilizando o mesmo procedimento medindo-se o $\mathrm{pH}$ em cada ensaio os resultados foram: 


\begin{tabular}{|c|c|c|c|c|c|c|c|c|c|c|c|c|c|}
\hline \multicolumn{14}{|c|}{ Combinação de cada ensaio } \\
\hline & & 1 & 2 & \multicolumn{2}{|l|}{3} & \multicolumn{2}{|l|}{4} & \multicolumn{2}{|l|}{5} & 6 & \multicolumn{2}{|r|}{7} & 8 \\
\hline 1 & & 1 & 1 & \multicolumn{2}{|l|}{1} & \multicolumn{2}{|l|}{1} & \multicolumn{2}{|l|}{-1} & -1 & \multicolumn{2}{|r|}{-1} & -1 \\
\hline 2 & & 1 & 1 & \multicolumn{2}{|c|}{-1} & \multicolumn{2}{|l|}{-1} & \multicolumn{2}{|l|}{1} & 1 & \multicolumn{2}{|r|}{-1} & -1 \\
\hline 3 & & 1 & -1 & \multicolumn{2}{|l|}{1} & \multicolumn{2}{|l|}{-1} & \multicolumn{2}{|l|}{1} & -1 & \multicolumn{2}{|r|}{1} & -1 \\
\hline 4 & & 1 & 1 & \multicolumn{2}{|l|}{-1} & \multicolumn{2}{|l|}{-1} & \multicolumn{2}{|l|}{-1} & -1 & \multicolumn{2}{|r|}{1} & 1 \\
\hline 5 & & 1 & -1 & \multicolumn{2}{|l|}{1} & \multicolumn{2}{|l|}{-1} & \multicolumn{2}{|l|}{-1} & 1 & \multicolumn{2}{|r|}{-1} & 1 \\
\hline 6 & & 1 & -1 & -1 & & 1 & & 1 & & -1 & & -1 & 1 \\
\hline 7 & & 1 & -1 & -1 & & 1 & & -1 & & 1 & & 1 & -1 \\
\hline Resultad & & 6,29 & 6,27 & 6,01 & & 5,77 & & 6,27 & & 6,40 & & 6,02 & 5,96 \\
\hline $\begin{array}{l}\text { Teste para } \\
\text { Referência: }\end{array}$ & $\begin{array}{l}\text { verifica } \\
\text { Vander } \mathrm{H}\end{array}$ & $\begin{array}{l}\text { ção de signif } \\
\text { Heyden, e col., }\end{array}$ & Pharm. B & $\begin{array}{l}\text { efeitos } \\
\text { iomed. Anal. }\end{array}$ & $\begin{array}{l}4(2001) 7 \\
\text { cálculos̀ }\end{array}$ & $\begin{array}{l}\text { 23-753. } \\
\text { para obte }\end{array}$ & tenção do & os valores & de ME & e SME sã & o baseac & dos no algorit & itmo de Dong \\
\hline Fator & Efeitos & $\begin{array}{r}\text { Ordenamento } \\
\text { Efeitos }\end{array}$ & $\begin{array}{r}\text { Efeitos } \\
\text { Absolutos }\end{array}$ & $\begin{array}{r}\text { Ordenamento } \\
\text { Absoluto }\end{array}$ & $\begin{array}{l}\text { Quadrado } \\
\text { Orden Abs }\end{array}$ & Ordem & & & & (Ф) & Rankit & $\begin{array}{l}\text { Orden. Efeitos } \\
\text { Abs }\end{array}$ & 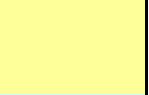 \\
\hline 1 & $-0,08$ & $-0,10$ & $0,10^{\prime}$ & 0,01 & 0,00 & 1 & 0,07143 & $-1,4652$ & 0 & 0,54 & 0,09 & 0,01 & $0,125 \quad 0,19624$ \\
\hline 2 & 0,37 & $-0,08$ & 0,08 & 0,02 & 0,00 & 2 & 0,21429 & $-0,7916$ & 0 & 0,61 & 0,27 & 0,02 & \\
\hline 3 & 0,05 & $-0,01$ & 0,01 & $0,05^{\prime \prime}$ & 0,00 & 3 & 0,35714 & $-0,3661$ & 0 & 0,68 & 0,46 & 0,05 & \\
\hline 4 & 0,02 & 0,02 & 0,02 & $0,08^{\prime \prime}$ & 0,01 & 4 & 0,5 & 0 & 0 & 0,75 & 0,67 & 0,08 & \\
\hline 5 & 0,08 & 0,05 & 0,05 & 0,08 & 0,01 & 5 & 0,64286 & 0,36611 & 0 & 0,82 & 0,92 & 0,08 & \\
\hline 6 & $-0,10$ & 0,08 & 0,08 & $0,10^{\prime}$ & 0,01 & 6 & 0,78571 & 0,79164 & 0 & 0,89 & 1,24 & 0,10 & \\
\hline 7 & $-0,01$ & 0,37 & $0,37^{\prime}$ & $0,37^{\prime \prime}$ & 0,14 & 7 & 0,92857 & 1,46523 & 0 & 0,96 & 1,80 & 0,37 & $0,125 \quad 0,19624$ \\
\hline média & 0,05 & & soma & & 0,16 & & & $\begin{array}{r}\text { mediana } \\
\mathrm{s}_{\mathrm{o}}\end{array}$ & \begin{tabular}{|r}
0,0775 \\
0,12
\end{tabular} & & 6 & IC, \% & 95 \\
\hline Erro Padrão ` & 0,15 & & & & & & & $\begin{array}{c}2,5^{*} \mathrm{~s}_{0} \\
\mathrm{~s}_{1}\end{array}$ & \begin{tabular}{|c|}
0,29 \\
0,05104
\end{tabular} & $\begin{array}{r}\text { ME" } \\
\text { SME" }\end{array}$ & $\begin{array}{l}0,12489 \\
0,19624 \\
\end{array}$ & & $\begin{array}{r}0,05 \\
0,009 \\
\end{array}$ \\
\hline
\end{tabular}

Figura 28: Teste para verificação da significância dos efeitos para os valores da resposta da medição do $\mathrm{pH}$.

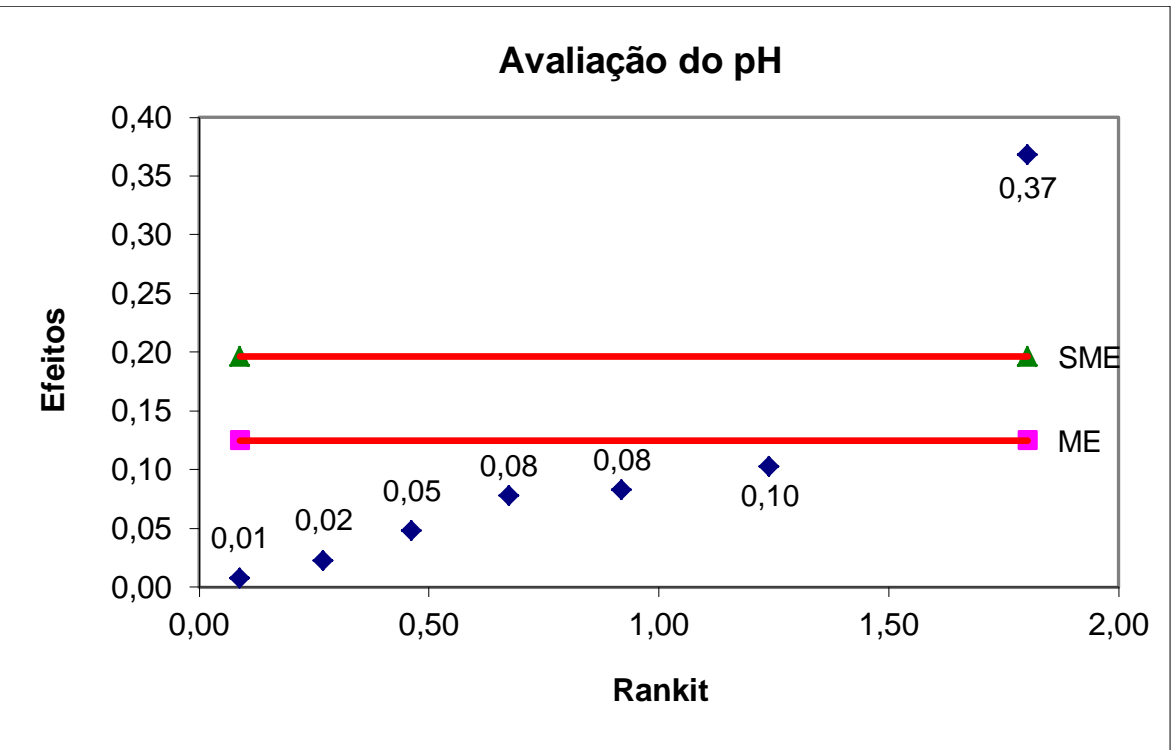

Figura 29: Gráfico de Rankit para pH. 
No caso do $\mathrm{pH}$ a legislação ambiental estabelece o descarte do efluente em um intervalo entre 6 e 9 , desta forma as combinações de fatores devem conduzir o sistema para esta faixa.

Observou-se que o fator 2 é o mais sensível a esse processo, sendo a massa de $\mathrm{NaHCO}_{3}$ um agente com influência positiva para o aumento do $\mathrm{pH}$.

Os demais fatores, tais como NaDCC, antiespumante e massa de adição, por se tratarem de valores negativos, oferecem uma baixa contribuição para o "não aumento" ou "diminuição do valor do pH. Dessa forma, o ajuste do pH pode ser realizado somente com a adição do $\mathrm{NaHCO}_{3}$.

\subsubsection{Avaliação do teor de Cloroaminas}

De acordo com a avaliação percebe-se que os fatores $2\left(\mathrm{NaHCO}_{3}\right)$ e 4 (essência) são os mais significativos para o aumento da concentração de Cloroaminas no meio reacional (efeitos positivos). $O$ fator 5 (corante) também contribui, porém de maneira menos intensa. Os demais fatores oferecem pouca influência na alteração da concentração de Cloroaminas, com exceção ao fator 6 (antiespumante), que participa com uma ligeira interferência para a "não formação" das cloroaminas no sistema.

A seguir, FIG. 30 e 31, são apresentados os resultados para teor de Cloroaminas (em mg. $\mathrm{L}^{-1}$ ). 


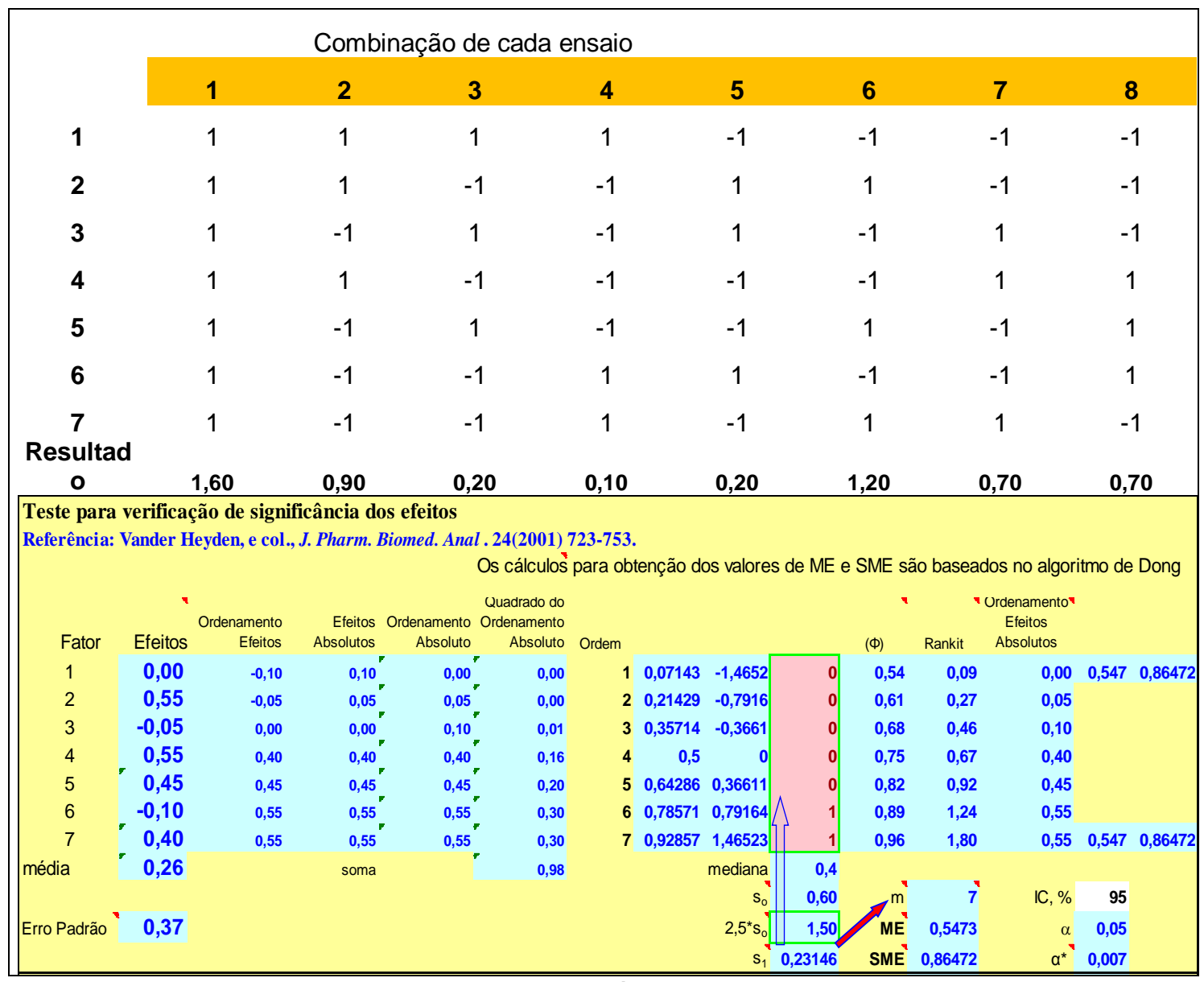

Figura 30: Teste para verificação da significância dos efeitos para os valores da resposta da medição de Cloroaminas.

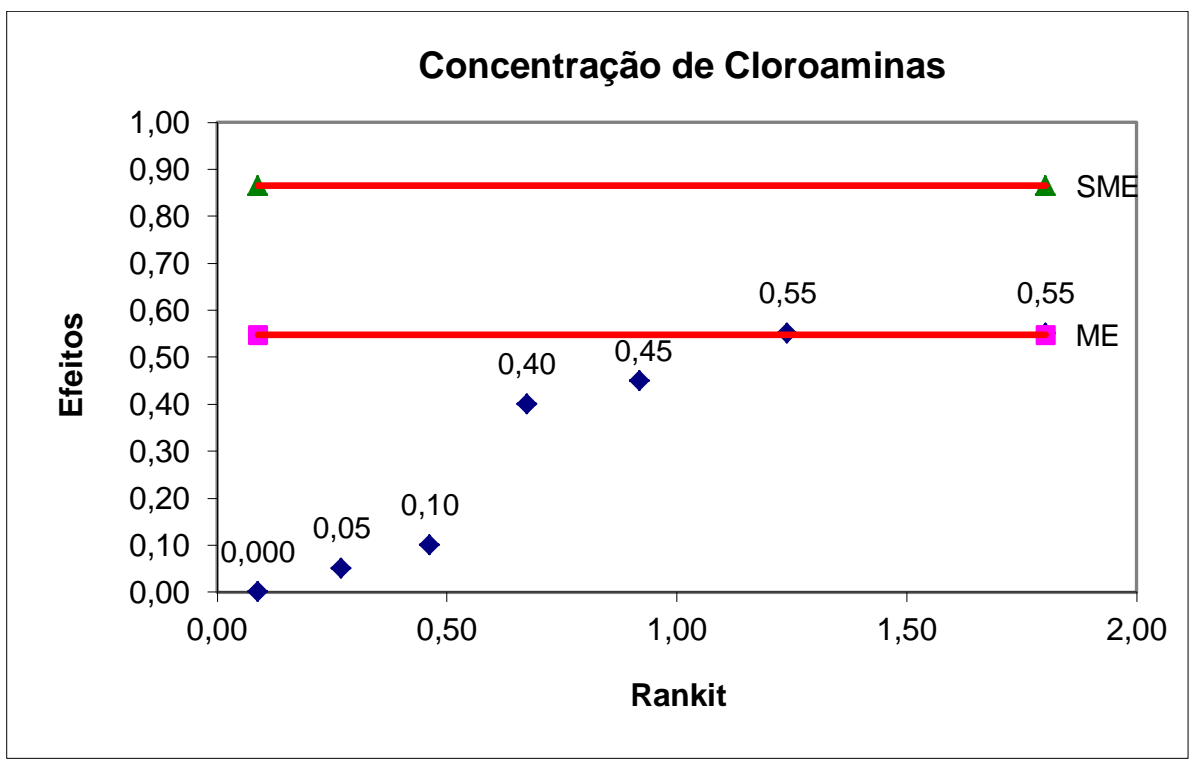

Figura 31: Gráfico de Rankit para teor de Cloroaminas. 


\subsubsection{Avaliação do teor de Monocloroamina}

Em relação à formação de monocloroaminas, o fator 7 (massa adicionada) é o mais influente. $\mathrm{O}$ fator 1 ( $\mathrm{NaDCC}$ ) também contribui, porém com menor significância, para o aumento da concentração de monocloroaminas na solução avaliada. Os demais fatores não são significativos para a alteração dos valores de monocloroaminas, com exceção $\mathrm{NaHCO}_{3}$, que aponta uma pequena contribuição para a "não formação" deste composto.

Nas FIG. 32 e 33 são apresentados os resultados para teor de Monocloroaminas (em $\left.\mathrm{mg} \cdot \mathrm{L}^{-1}\right)$.

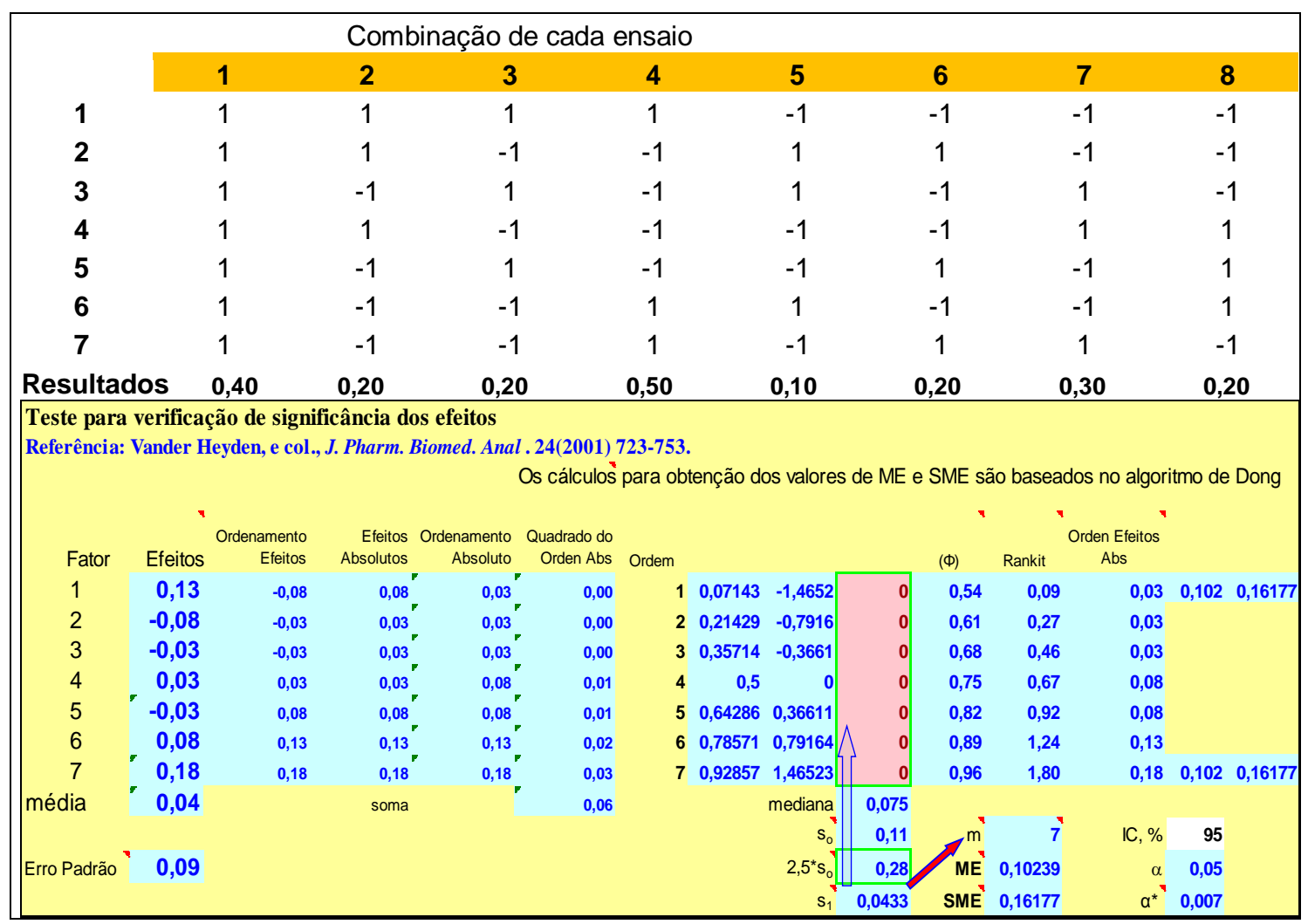

Figura 32: Teste de verificação da significância dos efeitos para os valores da resposta da medição de Monocloroaminas. 


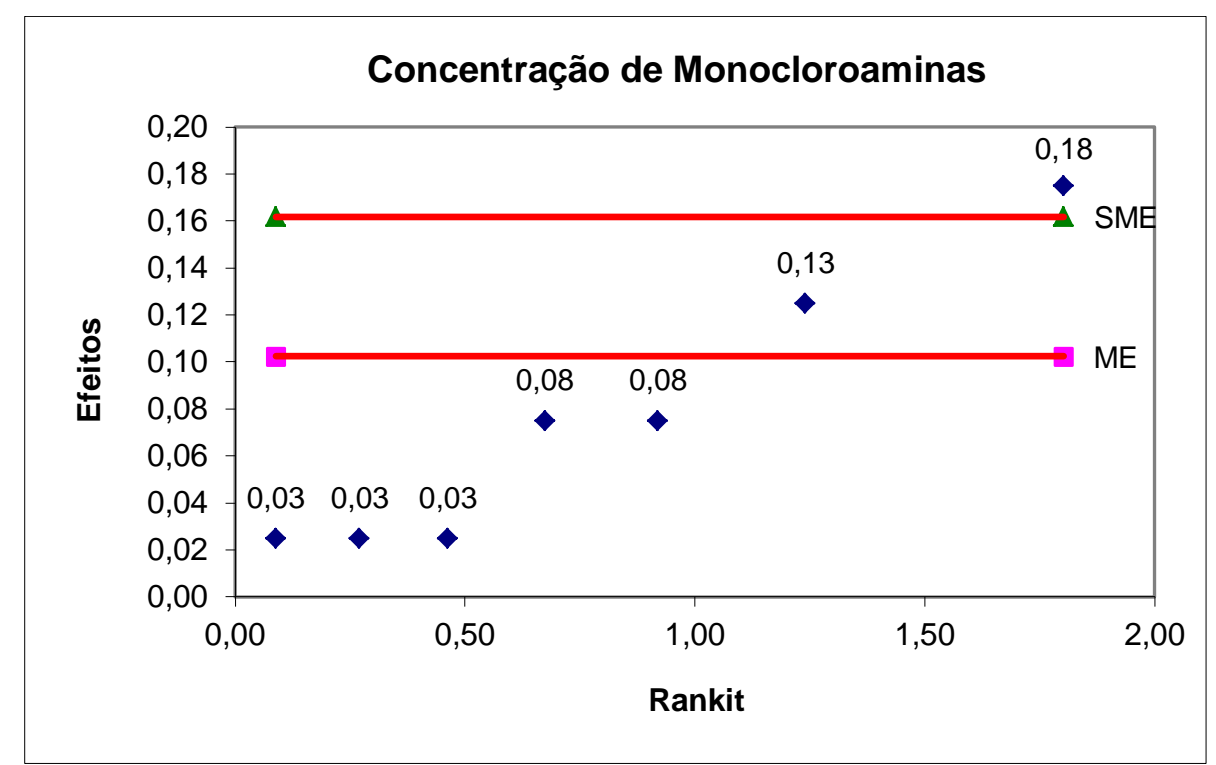

Figura 33: Gráfico de Rankit para Monocloroaminas.

\subsubsection{Avaliação da alteração da Cor}

Nas FIG. 34 e 35 são apresentados os resultados para Cor (em mg/L de $\mathrm{Pt} / \mathrm{Co})$.

Todos os itens avaliados neste experimento contribuem com um aumento na cor da solução. O fator $2\left(\mathrm{NaHCO}_{3}\right)$ é o menos positivo dentre os 7 fatores, desta maneira é o que mais contribui para o "não aumento" da cor da solução avaliada. O fator 3 (amido) é o mais influente para o aumento da cor no sistema reacional. 


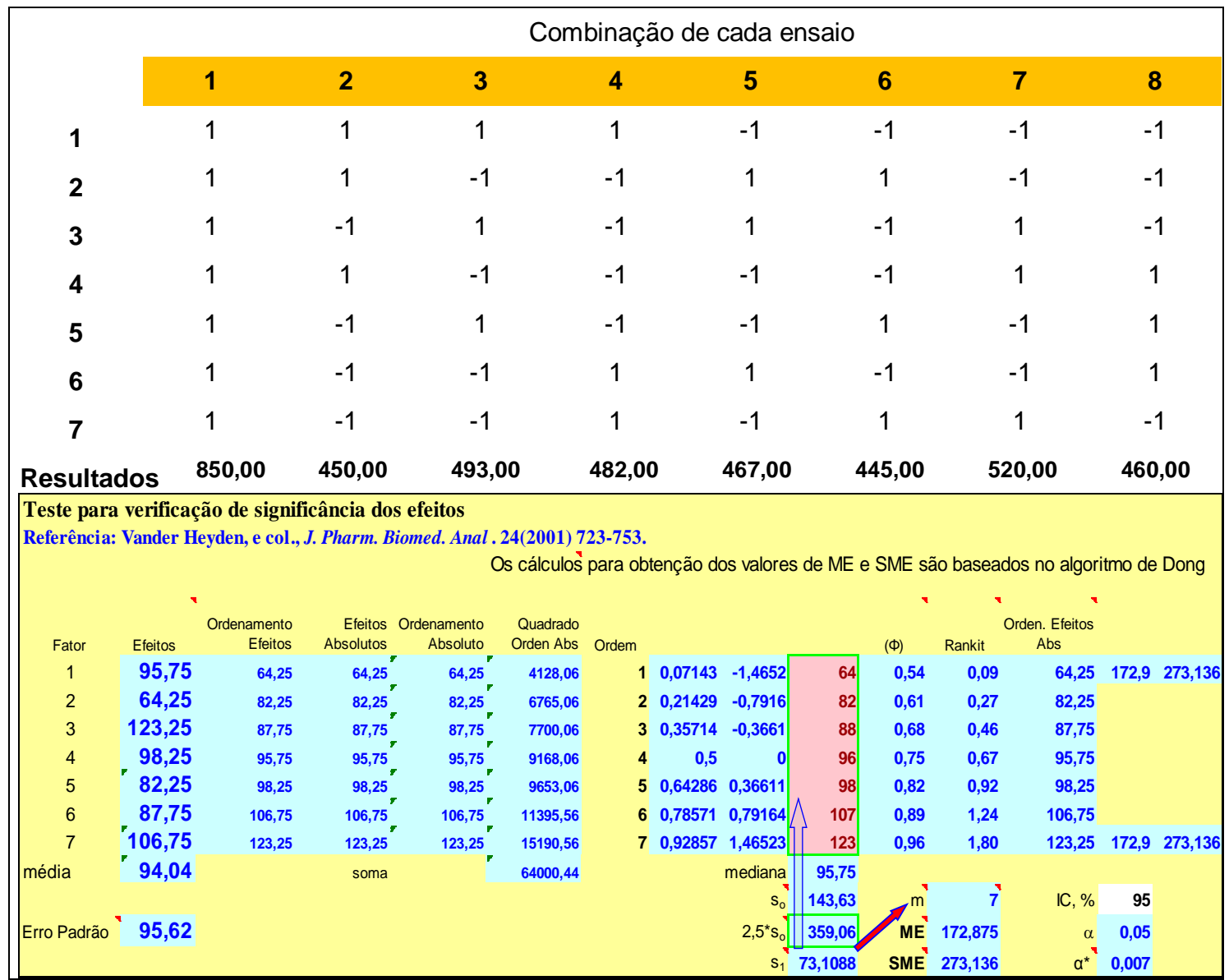

Figura 34: Teste para verificação da significância dos efeitos para os valores da resposta da medição de Cor.

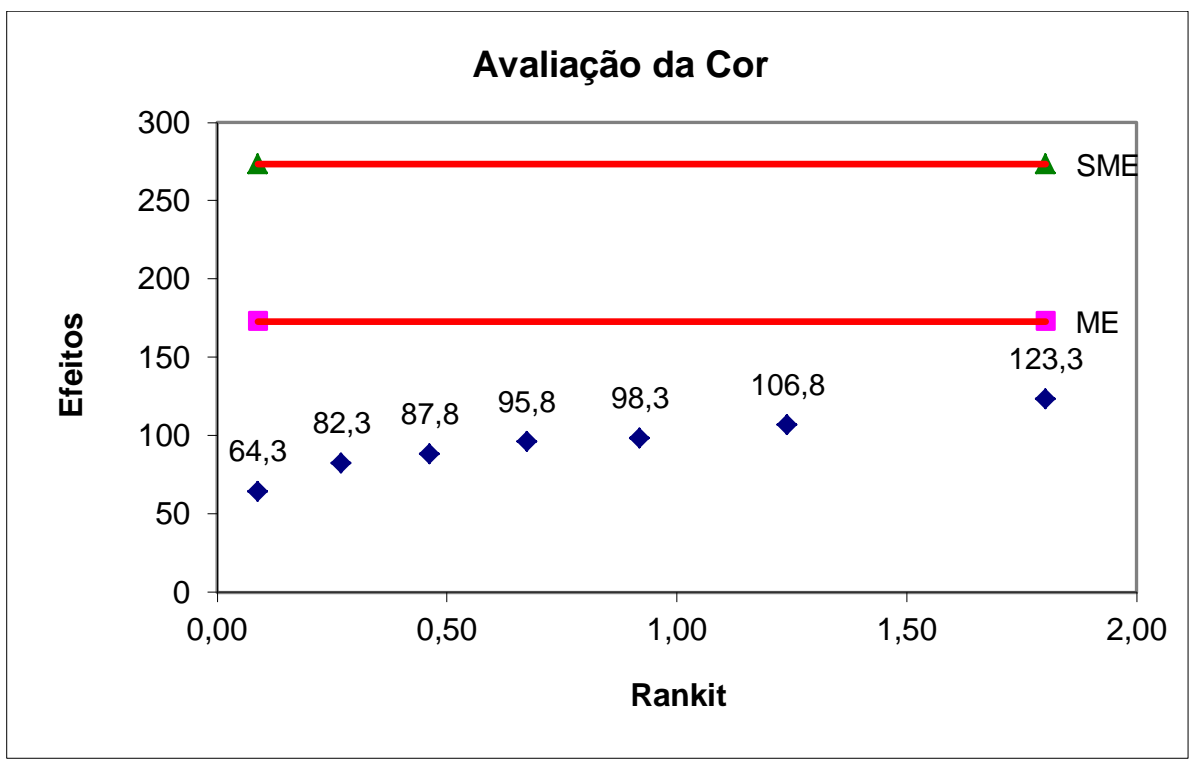

Figura 35: Gráfico de Rankit para Cor. 


\subsubsection{Avaliação da alteração da Turbidez}

A maior contribuição para o aumento da turbidez neste experimento é o fator 3 (amido). Os fatores 4 (essência) e 7 (massa de adição) também corroboram para que o meio fique com uma maior turbidez. A adição de NaDCC e corante, nessa ordem de importância, são dois fatores que influenciam para o "não aumento" da turbidez do meio. Nas FIG. 36 e 37 são apresentados os resultados para Turbidez (em NTU).

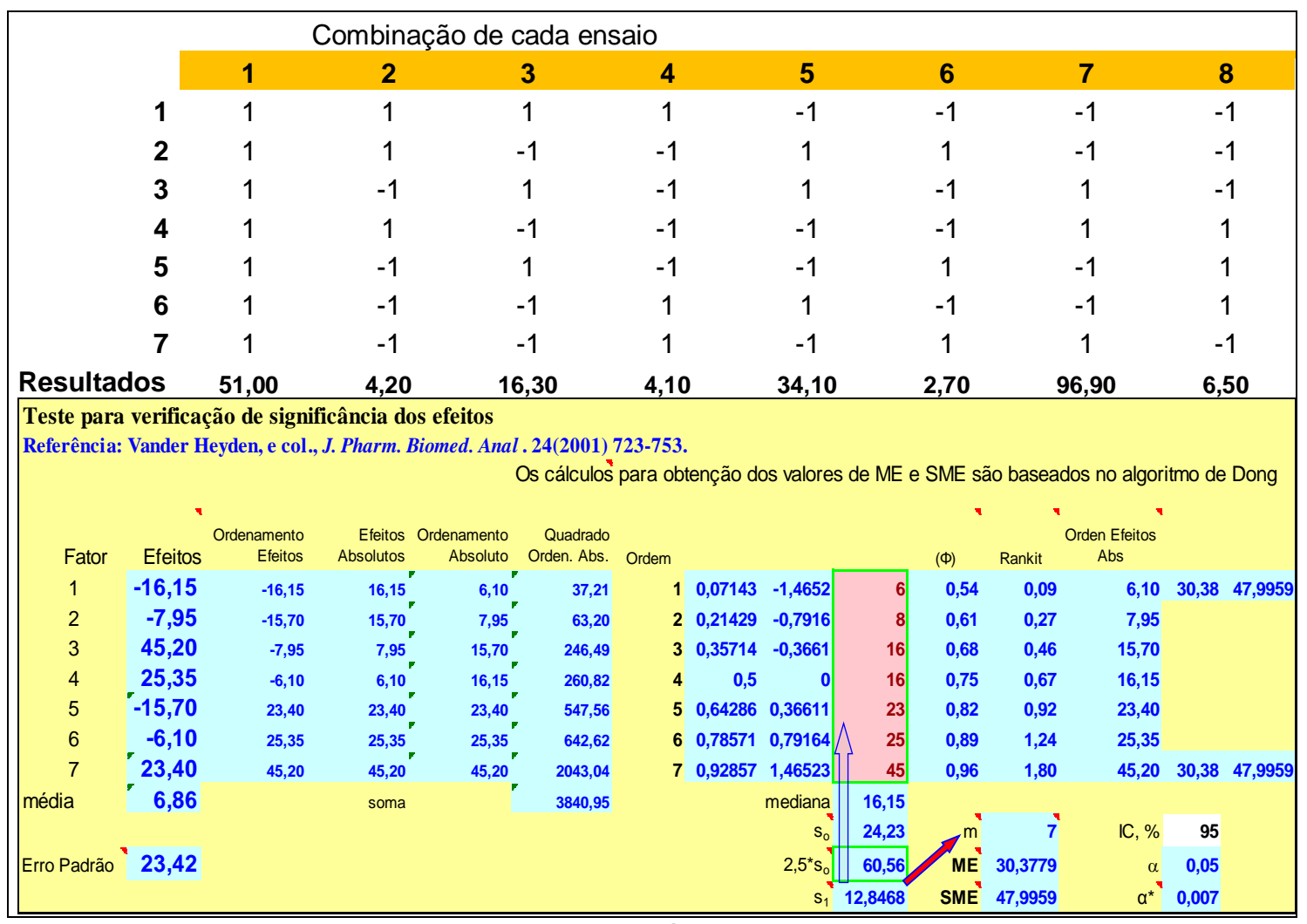

Figura 36: Teste para verificação da significância dos efeitos para os valores da resposta da medição da Turbidez. 


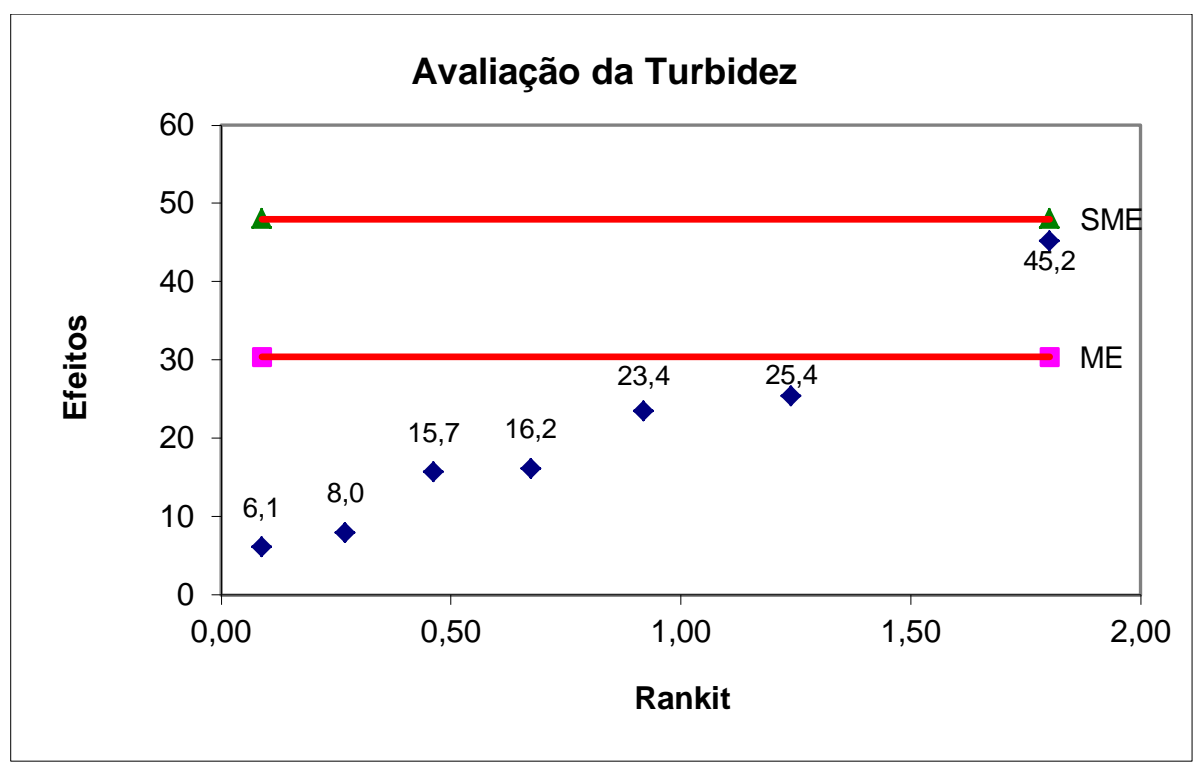

Figura 37: Gráfico de Rankit para Turbidez .

\subsubsection{Avaliação da alteração da DQO}

De acordo com o gráfico, o fator 4 (essência) apresenta-se como 0 mais significativo para o aumento da DQO na solução de urina, seguido do fator 3 (amido). O antiespumante (fator 6) favorece o "não aumento" da Demanda Química de Oxigênio do meio.

Nas FIG. 38 e 39 são apresentados os resultados para DQO (em $\mathrm{mg} \mathrm{L}^{-1}$ de $\mathrm{O}_{2}$ ). 


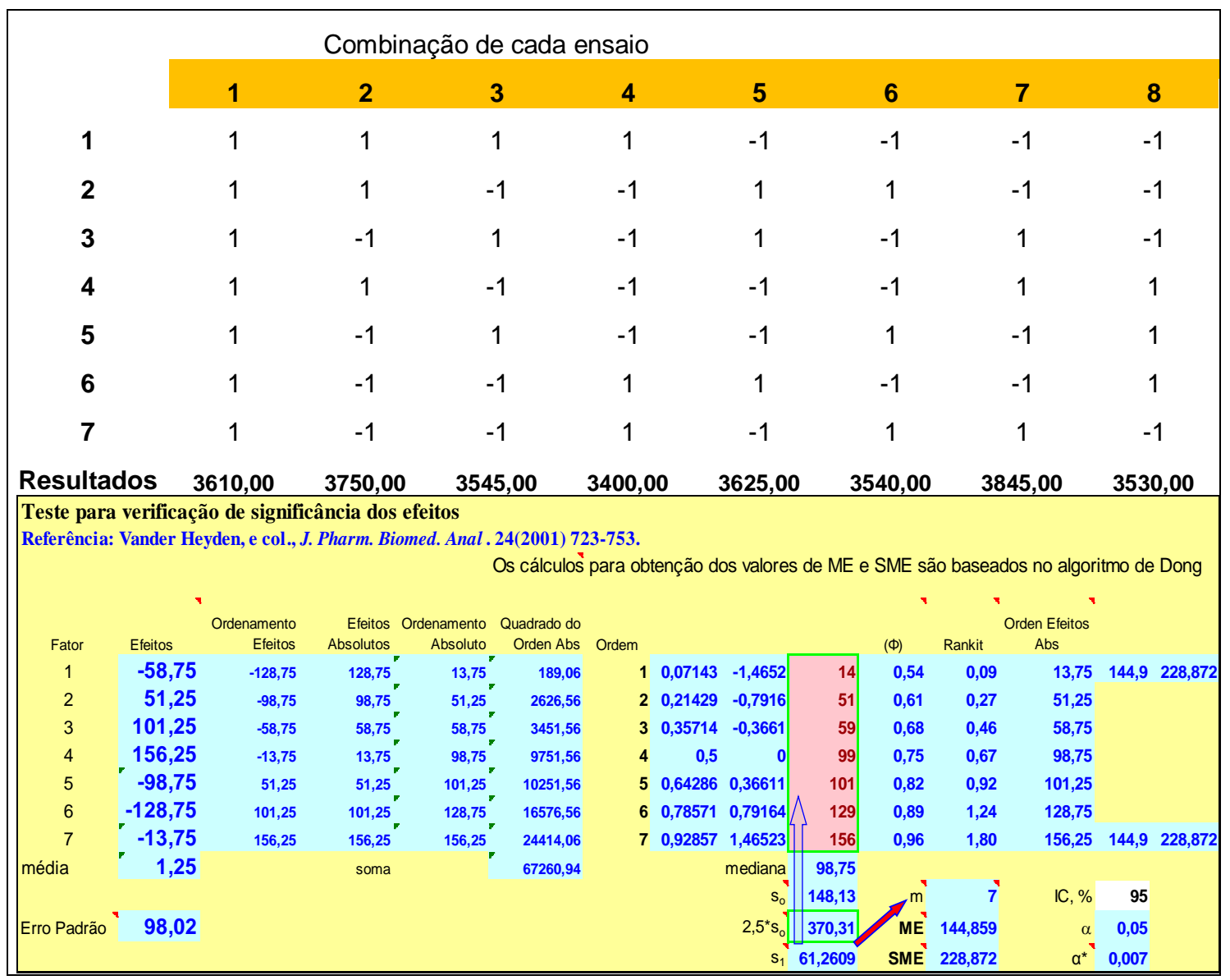

Figura 38: Teste para verificação da significância dos efeitos para os valores da resposta da medição da DQO.

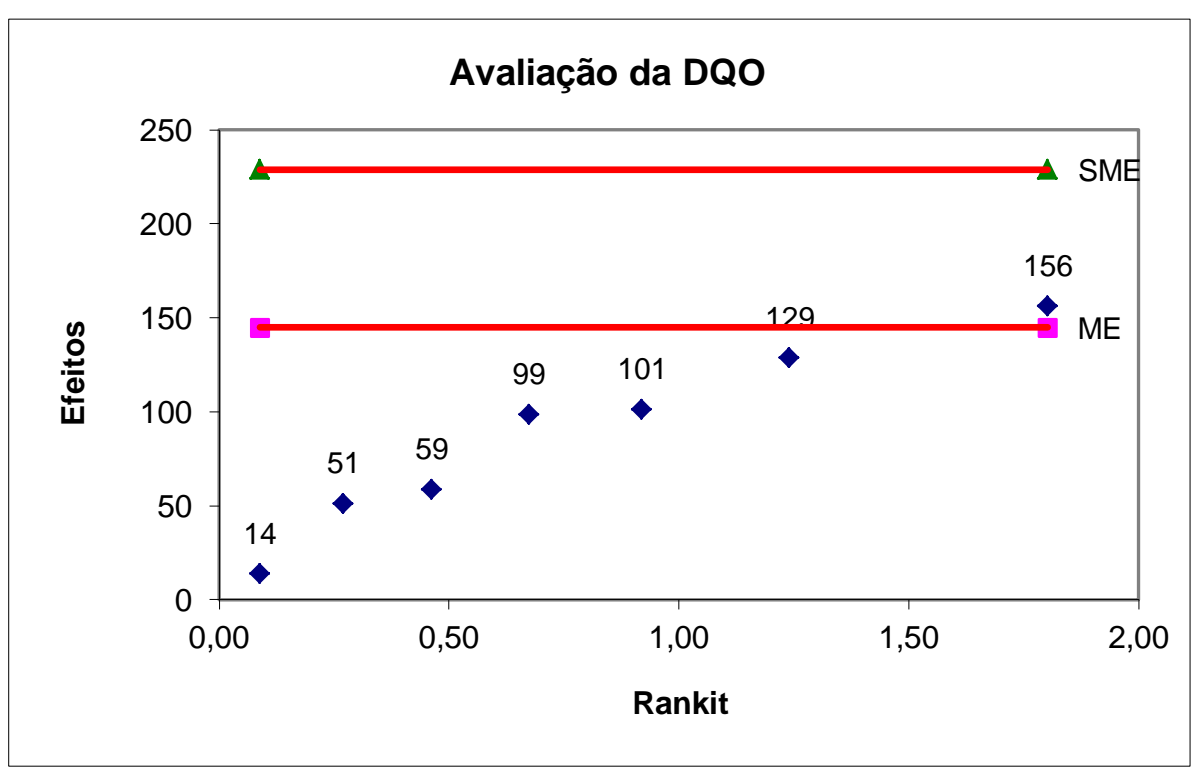

Figura 39: Gráfico de Rankit para DQO. 


\subsubsection{Avaliação da alteração do Cloro Livre}

A disponibilidade de Cloro Livre no sistema é mais influenciada pela presença de antiespumante (fator 6 ), sendo este componente um atenuador desta formação no meio. Observa-se também que a massa de adição (fator 7) e $\mathrm{NaHCO}_{3}$ (fator 2) contribuem para a redução do Cloro Livre na solução de urina. Amido (fator 3 ) e corante (fator 5) favorecem a formação de Cloro Livre.

Nas FIG. 40 e 41 são apresentados os resultados para Cloro Livre (em $\mathrm{mg} \cdot \mathrm{L}^{-1}$ de $\mathrm{Cl}$ ).

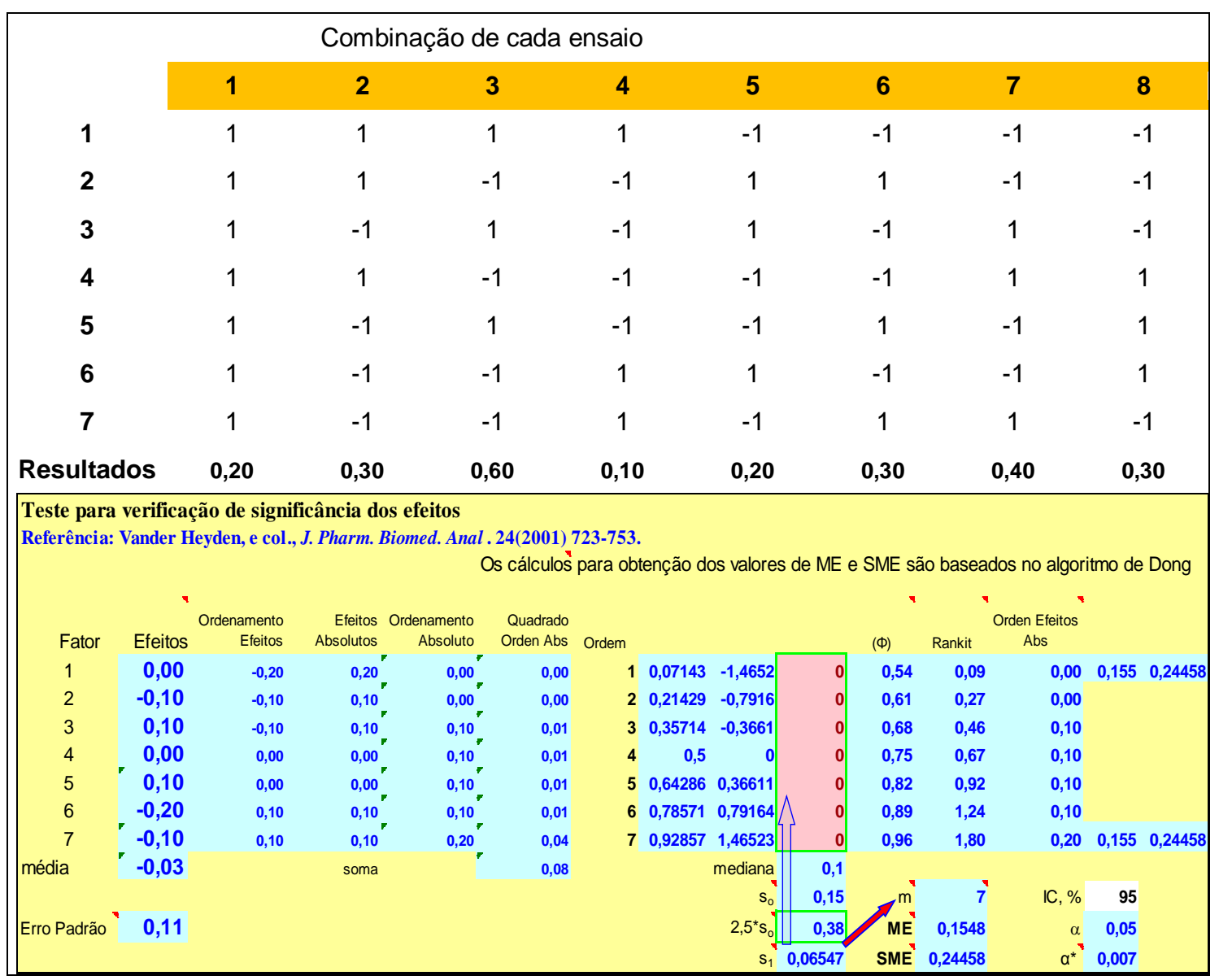

Figura 40: Teste para verificação da significância dos efeitos para os valores da resposta da medição do Cloro Livre. 


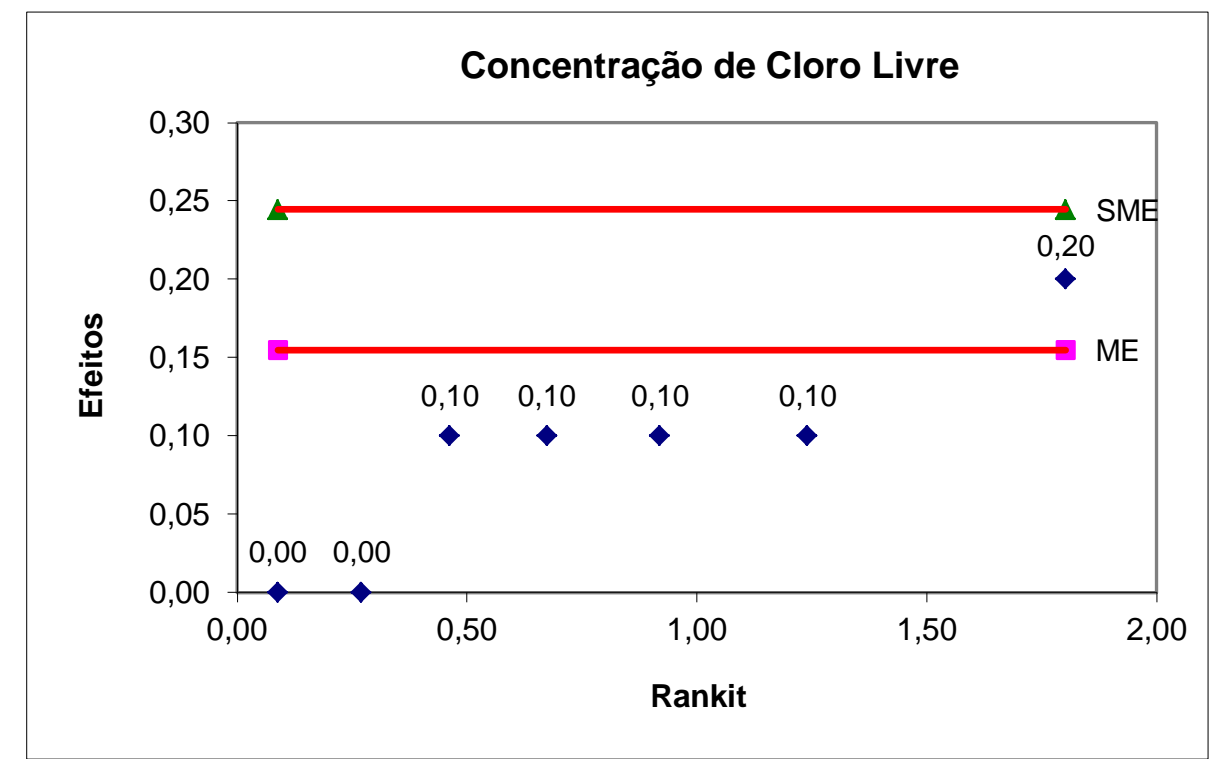

Figura 41: Gráfico de Rankit para Cloro Livre.

\subsubsection{Avaliação da alteração do Cloro Total}

Neste caso nota-se que o antiespumante (fator 6), da mesma forma que no exemplo anterior, é decisivo para inibição da concentração de Cloro Total no sistema. Em nível de mesma importância e intensidade, os fatores 4 (essência) e 5 (corante) são muito significativos para o aumento de Cloro Total no meio reacional.

Nas FIG. 42 e 43 são apresentados os resultados para Cloro Total (em $\left.\mathrm{mg} \cdot \mathrm{L}^{-1} \mathrm{de} \mathrm{Cl}\right)$. 


\begin{tabular}{|c|c|c|c|c|c|c|c|c|c|c|c|c|c|}
\hline \multicolumn{14}{|c|}{ Combinação de cada ensaio } \\
\hline & & 1 & 2 & \multicolumn{2}{|r|}{3} & \multicolumn{2}{|l|}{4} & \multicolumn{2}{|l|}{5} & 6 & \multicolumn{2}{|r|}{7} & 8 \\
\hline \multicolumn{2}{|l|}{1} & 1 & 1 & \multicolumn{2}{|r|}{1} & \multicolumn{2}{|l|}{1} & \multicolumn{2}{|l|}{-1} & -1 & \multicolumn{2}{|r|}{-1} & -1 \\
\hline \multicolumn{2}{|l|}{2} & 1 & 1 & \multicolumn{2}{|r|}{-1} & \multicolumn{2}{|l|}{-1} & \multicolumn{2}{|l|}{1} & 1 & \multicolumn{2}{|r|}{-1} & -1 \\
\hline 3 & & 1 & -1 & \multicolumn{2}{|r|}{1} & \multicolumn{2}{|l|}{-1} & \multicolumn{2}{|l|}{1} & -1 & \multicolumn{2}{|r|}{1} & -1 \\
\hline 4 & & 1 & 1 & \multicolumn{2}{|r|}{-1} & \multicolumn{2}{|l|}{-1} & \multicolumn{2}{|l|}{-1} & -1 & \multicolumn{2}{|r|}{1} & 1 \\
\hline 5 & & 1 & -1 & \multicolumn{2}{|r|}{1} & \multicolumn{2}{|l|}{-1} & \multicolumn{2}{|l|}{-1} & 1 & \multicolumn{2}{|r|}{-1} & 1 \\
\hline 6 & & 1 & -1 & \multicolumn{2}{|r|}{-1} & \multicolumn{2}{|l|}{1} & \multicolumn{2}{|l|}{1} & -1 & \multicolumn{2}{|r|}{-1} & 1 \\
\hline 7 & & 1 & -1 & \multicolumn{2}{|r|}{-1} & 1 & & -1 & & 1 & & 1 & -1 \\
\hline Resultad & dos & 1,90 & 1,10 & & 0,70 & 0,20 & & 0,40 & & 1,50 & & 1,10 & 1,00 \\
\hline $\begin{array}{l}\text { Teste para } \\
\text { Referência: }\end{array}$ & $\begin{array}{l}\text { verificaç } \\
\text { Vander } \mathrm{H}\end{array}$ & $\begin{array}{l}\text { ção de signi } \\
\text { leyden, e col., }\end{array}$ & $\begin{array}{l}\text { cância do } \\
\text { J. Pharm. B }\end{array}$ & $\begin{array}{l}\text { S efeitos } \\
\text { iomed. Anal }\end{array}$ & $\begin{array}{l}\text { Os cálculoș } \\
\text { Os }\end{array}$ & $\begin{array}{l}23-753 . \\
\text { para obte }\end{array}$ & tenção do & os valores & de ME e & e SME sã & io baseac & dos no algorit & tmo de Dong \\
\hline Fator & Efeitos & $\begin{array}{r}\text { Ordenamento } \\
\text { Efeitos }\end{array}$ & $\begin{array}{r}\text { Efeitos } \\
\text { Absolutos }\end{array}$ & $\begin{array}{r}\text { Ordenamento } \\
\text { Absoluto }\end{array}$ & $\begin{array}{r}\text { Quadrado do } \\
\text { Orden Abs }\end{array}$ & Ordem & & & & (Ф) & Rankit & $\begin{array}{c}\text { Orden Efeitos } \\
\text { Abs }\end{array}$ & \\
\hline 1 & $-0,02$ & $-0,23$ & 0,23 & $0,02^{\prime}$ & $\quad 0,00$ & 1 & 0,07143 & $-1,4652$ & 0 & 0,54 & 0,09 & 0,02 & $\begin{array}{ll}0,581 & 0,91853\end{array}$ \\
\hline 2 & 0,48 & $-0,02$ & $0,02^{\prime \prime}$ & $0,08^{\prime}$ & 0,01 & 2 & 0,21429 & $-0,7916$ & 0 & 0,61 & 0,27 & 0,08 & \\
\hline 3 & 0,08 & 0,08 & 0,08 & 0,23 & 0,05 & 3 & 0,35714 & $-0,3661$ & 0 & 0,68 & 0,46 & 0,23 & \\
\hline 4 & 0,58 & 0,38 & 0,38 & 0,38 & 0,14 & 4 & 0,5 & 0 & 0 & 0,75 & 0,67 & 0,38 & \\
\hline 5 & 0,58 & 0,48 & $0,48^{\prime}$ & $0,48^{\prime}$ & 0,23 & 5 & 0,64286 & 0,36611 & 0 & 0,82 & 0,92 & 0,48 & \\
\hline 6 & $-0,23$ & 0,58 & $0,58^{\prime \prime}$ & $0,58^{\prime \prime}$ & 0,33 & 6 & 0,78571 & $0,79164 \triangle$ & 1 & 0,89 & 1,24 & 0,58 & \\
\hline 7 & 0,38 & 0,58 & $0,58^{\prime}$ & $0,58^{\prime \prime}$ & 0,33 & 7 & 0,92857 & $1,46523]$ & 1 & 0,96 & 1,80 & 0,58 & $0,581 \quad 0,91853$ \\
\hline média & 0,26 & & soma & & 1,08 & & & $\begin{array}{r}\text { mediana } \\
s_{0}\end{array}$ & $\begin{array}{r}0,375 \\
0,56 \\
\end{array}$ & & 7 & IC, \% & 95 \\
\hline Erro Padrão " & 0,39 & & & & & & & $\begin{array}{rl}2,5^{*} s_{0} & \sqrt{]} \\
s_{1} & 0\end{array}$ & $\begin{array}{r}1,41 \\
, 24586\end{array}$ & $\begin{array}{l}\text { ME' } \\
\text { SME' }\end{array}$ & $\begin{array}{l}0,58136 \\
0,91853\end{array}$ & & $\begin{array}{r}0,05 \\
0,007\end{array}$ \\
\hline
\end{tabular}

Figura 42: Teste para verificação da significância dos efeitos para os valores da resposta da medição do Cloro Total.

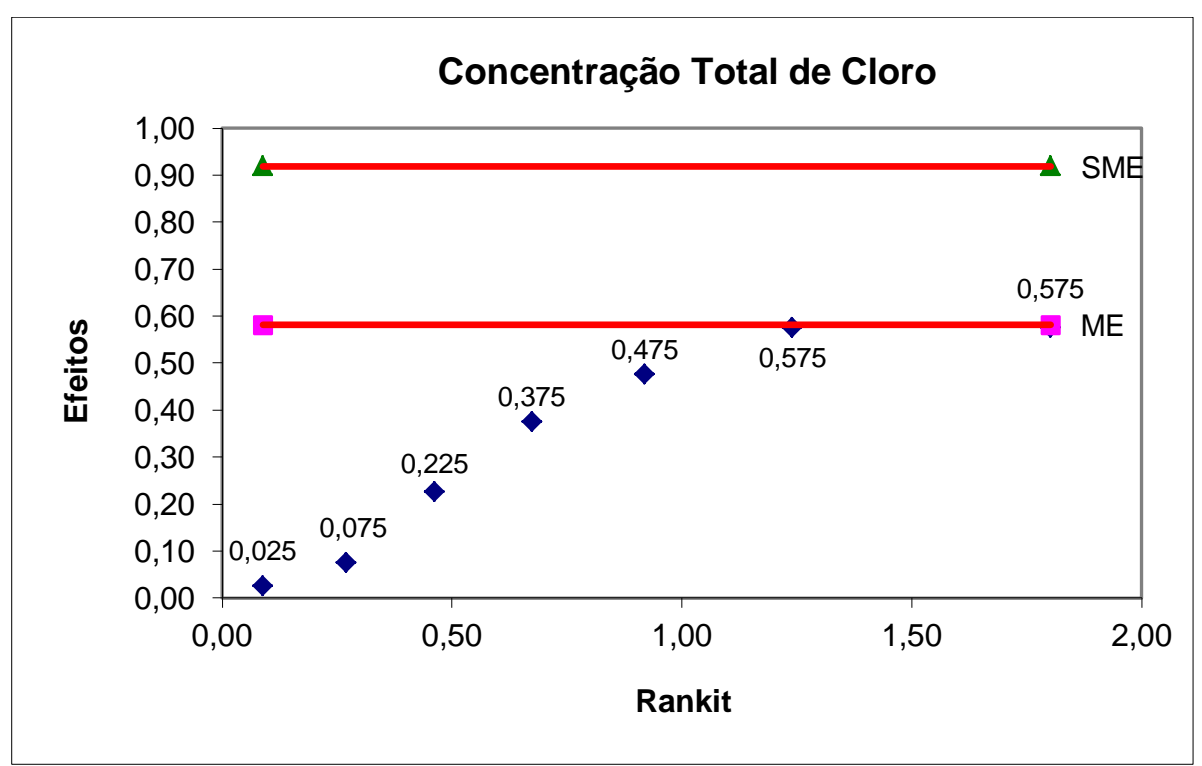

Figura 43: Gráfico de Rankit para Cloro Total. 
A TAB. 12 resume os efeitos de todos os fatores em relação aos parâmetros avaliados.

Tabela 12: Resumo dos efeitos para o planejamento fatorial realizado.

\begin{tabular}{l|c|c|c|c|c|c|c|c|c}
\hline \multicolumn{1}{c|}{ Fator } & $\mathbf{p H}$ & $\mathrm{NH}_{3}$ & $\mathrm{DQO}$ & $\mathrm{NTU}$ & $\begin{array}{c}\mathrm{Cl} \\
\text { Aminas }\end{array}$ & $\begin{array}{c}\text { M-Cloro } \\
\text { amina }\end{array}$ & $\begin{array}{c}\text { Cl } \\
\text { Livre }\end{array}$ & $\begin{array}{c}\text { Cl- } \\
\text { Total }\end{array}$ & Cor \\
\hline 1-NaDCC & - & --- & & -- & ++ & & & & ++ \\
\hline 2-NaHCO & $\begin{array}{c}++ \\
+\end{array}$ & -- & & & - & -- & -- & ++ & \\
\hline 3-Amido & & - & +++ & +++ & & ++ & ++ & & +++ \\
\hline 4-Essência & & & +++ & ++ & & & & +++ & ++ \\
\hline 5-Corante & & - & - & -- & & ++ & ++ & +++ & \\
\hline 6-Antiespumante & & +++ & --- & & + & --- & --- & --- & \\
\hline 7-Massa & & & & ++ & +++ & +++ & -- & + & ++ \\
\hline
\end{tabular}

OBS: Os sinais "+" ou "-" indicam fatores positivos e negativos para cada atributo avaliado. O número de vezes em que cada sinal aparece é relacionado à intensidade dos efeitos.

\subsubsection{Avaliação sensorial preliminar}

Como resultado preliminar coletou-se informações de 10 voluntários, escolhidos aleatoriamente, para classificar as 8 amostras do planejamento fatorial citado acima. Considerando uma escala entre 0 e 10, sendo intervalo 0 a 4 tido como insatisfatório (INS) e a faixa entre 5 e 10 reconhecida como satisfatória (SAT), os valores atribuídos pelos avaliadores estão representados na FIG. 44.

Nota-se que quão mais próximo da tonalidade amarela aumenta-se a tendência a repulsa por parte dos avaliadores. A tonalidade verde remete à impressão de tratamento. É importante ressaltar que neste teste também avaliouse o odor em cada um dos béqueres, portanto o veredito final levou em conta o conjunto visual e olfativo. 


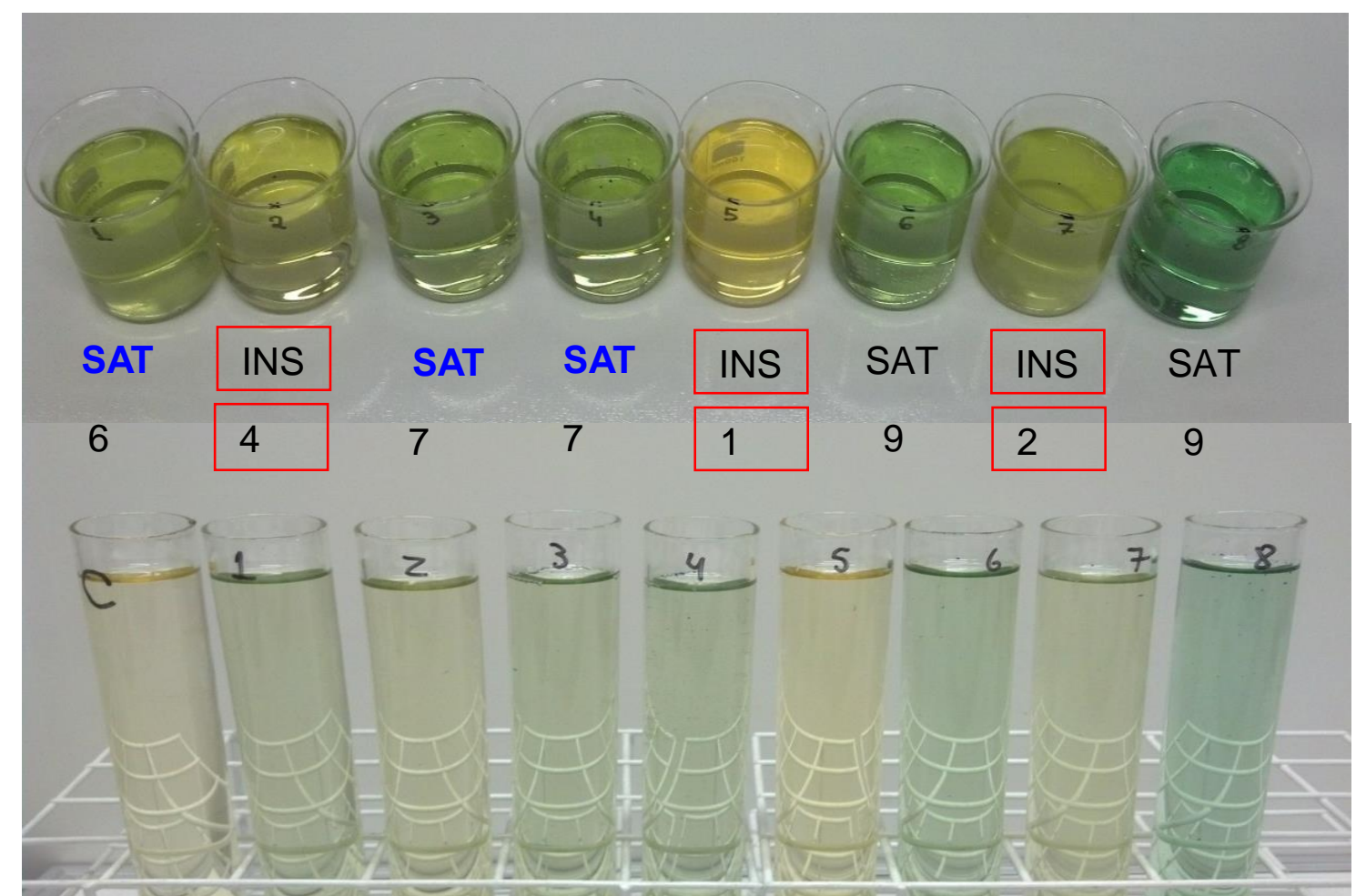

Figura 44: Resultado da avaliação sensorial preliminar.

Legenda: $\quad$ Os valores são as médias de notas atribuídas por 10 voluntários numa escala de 0 a 10.

\subsubsection{Testes com diferentes formulações}

Para avaliar a eficiência do método de tratamento da urina foram realizados alguns ensaios com 6 formulações diferentes. Em cada combinação apresentada verificou-se os aspectos sensoriais (odor e cor) e outros parâmetros físicos e químicos importantes.

Foi solicitado um teste em laboratório acreditado (independente) para averiguação dos principais parâmetros. 
Tabela 13: Resultados das diferentes formulações avaliadas.

\begin{tabular}{lcccccc}
\hline \multicolumn{1}{c}{ Componentes } & FM 1 & FM 2 & FM 3 & FM 4 & FM 5 & FM6 \\
\hline NaDCC & $1,00 \mathrm{~g}$ & $1,00 \mathrm{~g}$ & $0,50 \mathrm{~g}$ & $1,00 \mathrm{~g}$ & $1,0 \mathrm{~g}$ & $0,50 \mathrm{~g}$ \\
$\mathrm{NaHCO}_{3}$ & - & $0,50 \mathrm{~g}$ & $1,0 \mathrm{~g}$ & - & $0,50 \mathrm{~g}$ & $1,00 \mathrm{~g}$ \\
Amido & - & - & - & $0,60 \mathrm{~g}$ & $0,60 \mathrm{~g}$ & $0,60 \mathrm{~g}$ \\
Essência & $0,10 \mathrm{~g}$ & $0,10 \mathrm{~g}$ & $0,10 \mathrm{~g}$ & - & - & - \\
Corante verde & $0,01 \mathrm{~g}$ & $0,01 \mathrm{~g}$ & $0,01 \mathrm{~g}$ & $0,01 \mathrm{~g}$ & $0,01 \mathrm{~g}$ & $0,01 \mathrm{~g}$ \\
Antiespumante & $0,10 \mathrm{~g}$ & $0,10 \mathrm{~g}$ & $0,10 \mathrm{~g}$ & - & - & - \\
\hline Total & $1,21 \mathrm{~g}$ & $1,71 \mathrm{~g}$ & $1,61 \mathrm{~g}$ & $1,61 \mathrm{~g}$ & $2,11 \mathrm{~g}$ & $2,11 \mathrm{~g}$ \\
\hline
\end{tabular}

Tabela 14: Resultados dos testes para as 6 formulações e a amostra bruta (urina diluída).

\begin{tabular}{|c|c|c|c|c|c|c|c|c|}
\hline Parâmetro & Unidade & Bruta & FM 1 & FM 2 & FM 3 & FM 4 & FM 5 & FM 6 \\
\hline Amônia & $\mathrm{mg} / \mathrm{L}$ de $\mathrm{NH}_{3}$ & 272,00 & 119,50 & 136,50 & 153,00 & 170,20 & 187,80 & 189,80 \\
\hline N-Amoniacal & $\mathrm{mg} / \mathrm{L}$ de $\mathrm{N}$ & 223,04 & 97,99 & 111,93 & 125,46 & 139,56 & 154,00 & 155,64 \\
\hline Cloroaminas Total & $\mathrm{mg} / \mathrm{L}$ & $<0,1$ & 7,40 & 1,40 & 0,30 & 1,50 & 0,60 & 0,10 \\
\hline Monocloroamina & $\mathrm{mg} / \mathrm{L}$ de $\mathrm{Cl}$ & $<0,01$ & 0,59 & 0,19 & 0,09 & $<0,01$ & $<0,01$ & 0,09 \\
\hline Cor & $\begin{array}{c}\mathrm{mg} / \mathrm{L} \text { de } \\
\mathrm{PtCo}\end{array}$ & 850 & 304 & 325 & 303 & 506 & 401 & 418 \\
\hline Turbidez & UNT & 45,5 & 2,8 & 3,0 & 2,9 & 68,7 & 41,7 & 43,0 \\
\hline $\mathrm{pH}$ & - & 6,4 & 5,9 & 6,5 & 6,8 & 6,1 & 6,4 & 6,8 \\
\hline Cloro Livre & $\mathrm{mg} / \mathrm{L}$ de $\mathrm{Cl}$ & $<0,01$ & 0,00 & 0,00 & $<0,01$ & 0,00 & 0,00 & $<0,01$ \\
\hline Cloro Total & $\mathrm{mg} / \mathrm{L}$ de $\mathrm{Cl}$ & $<0,01$ & 7,4 & 1,4 & 0,30 & 1,50 & 0,60 & 0,10 \\
\hline Benzeno & $u g / L$ & $<1,00$ & $<1,00$ & $<1,00$ & $<1,00$ & $<1,00$ & $<1,00$ & $<1,00$ \\
\hline Tolueno & $u g / L$ & $<1,00$ & $<1,00$ & $<1,00$ & $<1,00$ & $<1,00$ & $<1,00$ & $<1,00$ \\
\hline Cálcio & $\mathrm{mg} / \mathrm{L}$ de $\mathrm{Ca}$ & 71,37 & 51,67 & 66,81 & 77,67 & 74,59 & 76,33 & 83,51 \\
\hline Sódio & $\mathrm{mg} / \mathrm{L}$ de $\mathrm{Na}$ & 716,93 & 568,26 & 923,22 & 904,33 & 1172,77 & 997,52 & 1125,22 \\
\hline DQO & $\mathrm{mg} / \mathrm{L}$ de $\mathrm{O}_{2}$ & 1795 & 2035 & 1970 & 1950 & 2180 & 2020 & 2150 \\
\hline
\end{tabular}




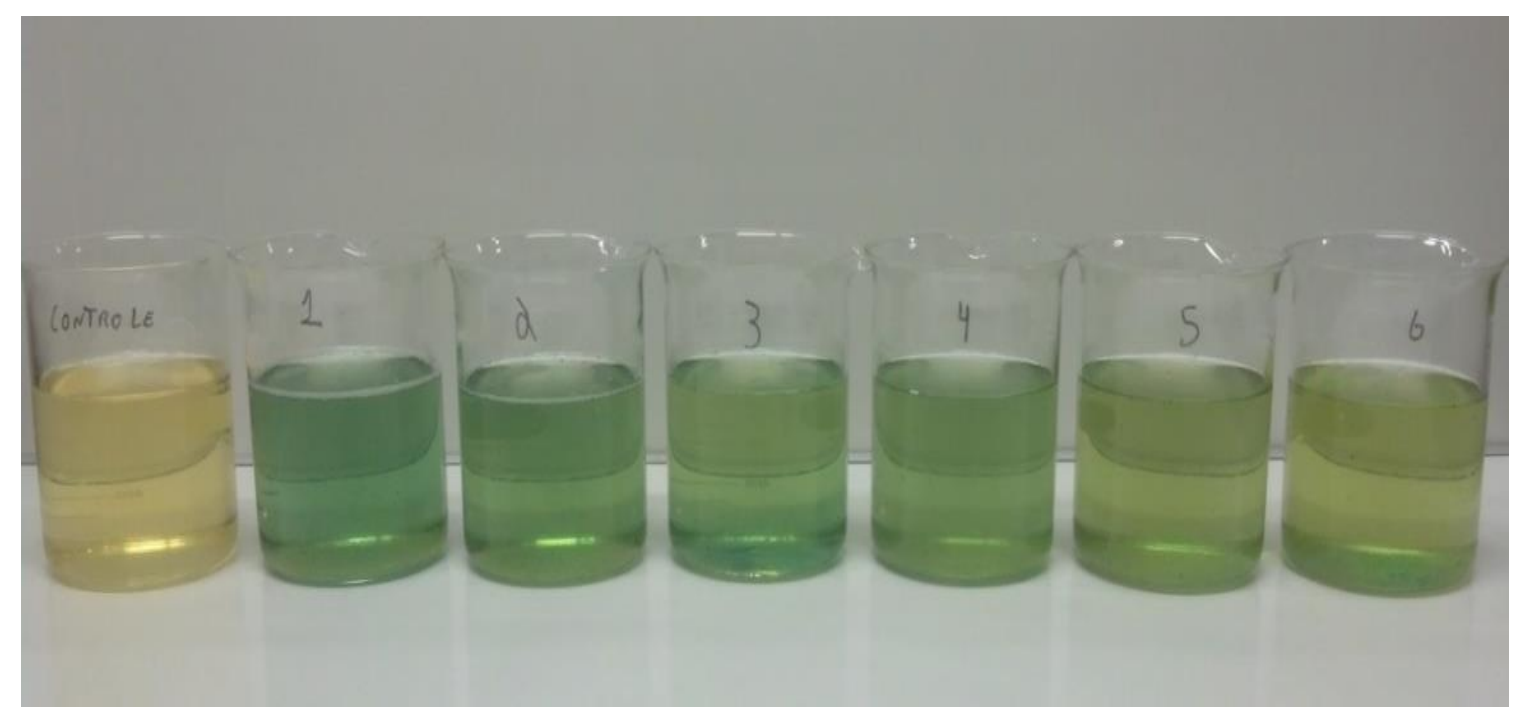

Figura 45: Avaliação dos béqueres imediatamente após a adição das massas.

A FIG. 45 ilustra os 6 béqueres contento as urinas diluídas imediatamente após adição das respectivas formulações. Nota-se uma menor formação de espuma nos béqueres de 4 a 6 , justamente os que apresentam antiespumante na composição da fórmula adicionada. Este fato é mais perceptível após certo tempo, como ilustrado nas FIG. 46 e 47.

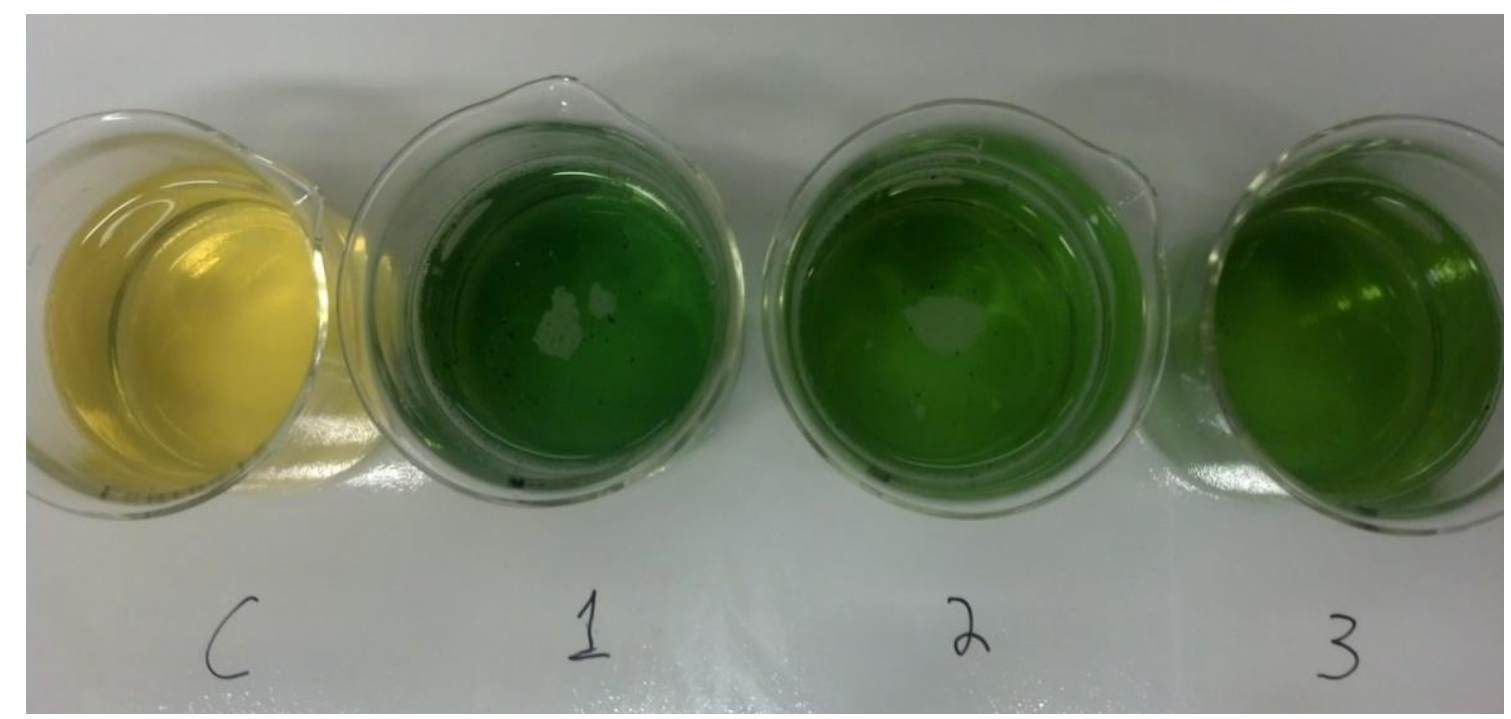

Figura 46: Avaliação dos béqueres imediatamente após 10 minutos da adição do produto. Visão superior dos Béqueres de 1 a 3 e do controle. 


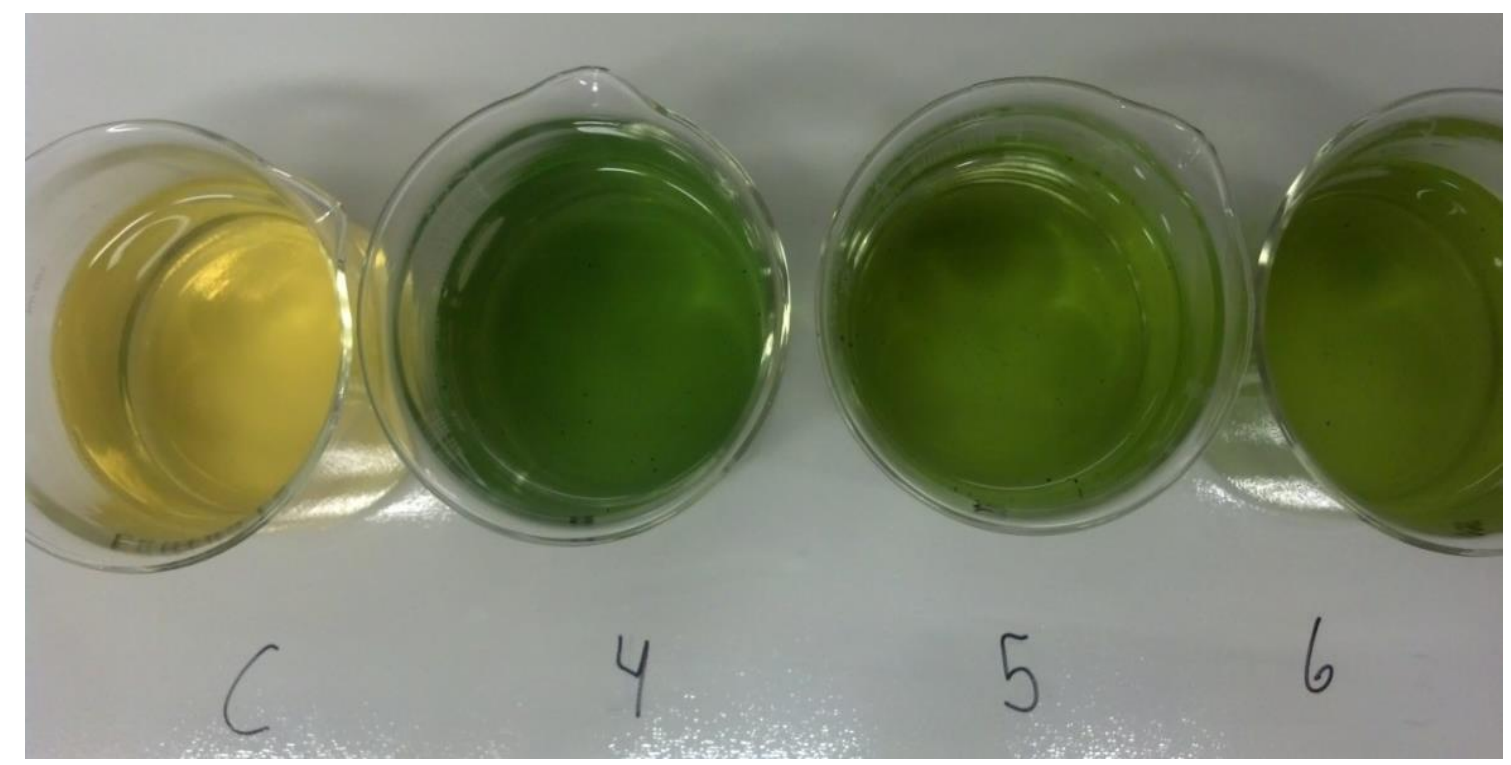

Figura 47: Avaliação dos béqueres imediatamente após 10 minutos da adição do produto. Visão superior dos Béqueres de 4 a 6 e do controle.

Nos testes ilustrados nas FIG. 48, 49 e 50, após 12 minutos, adicionouse um volume equivalente a uma carga de urina em cada béquer para simular uma maior concentração de urina no meio. Os béqueres identificados como 1/1carga; 2/1carga e 3/1carga, foram preparados paralelamente aos béqueres 1 , 2 e 3.

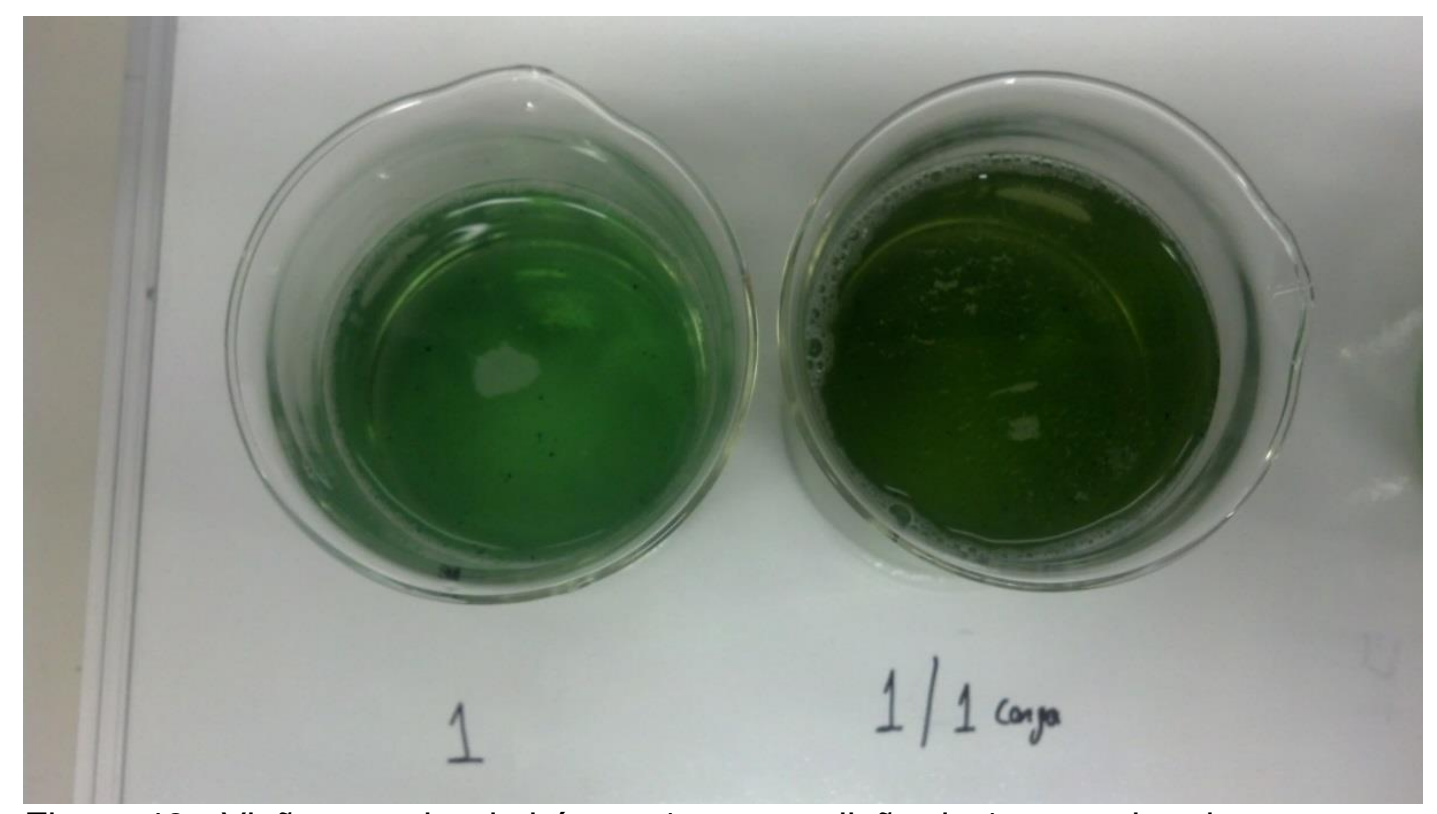

Figura 48: Visão superior do béquer 1 com a adição de 1 carga de urina. 


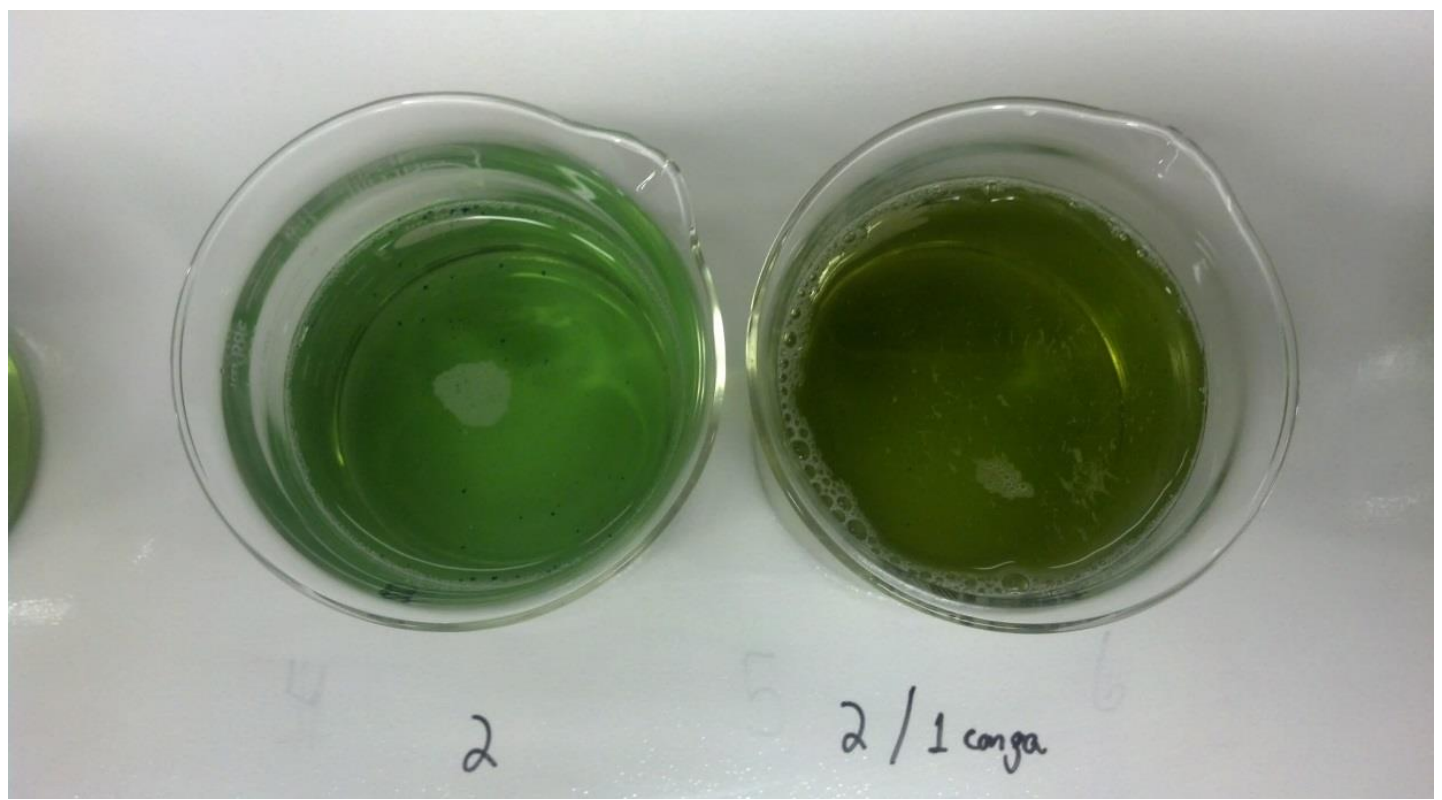

Figura 49: Visão superior do béquer 2 com a adição de 1 carga de urina.

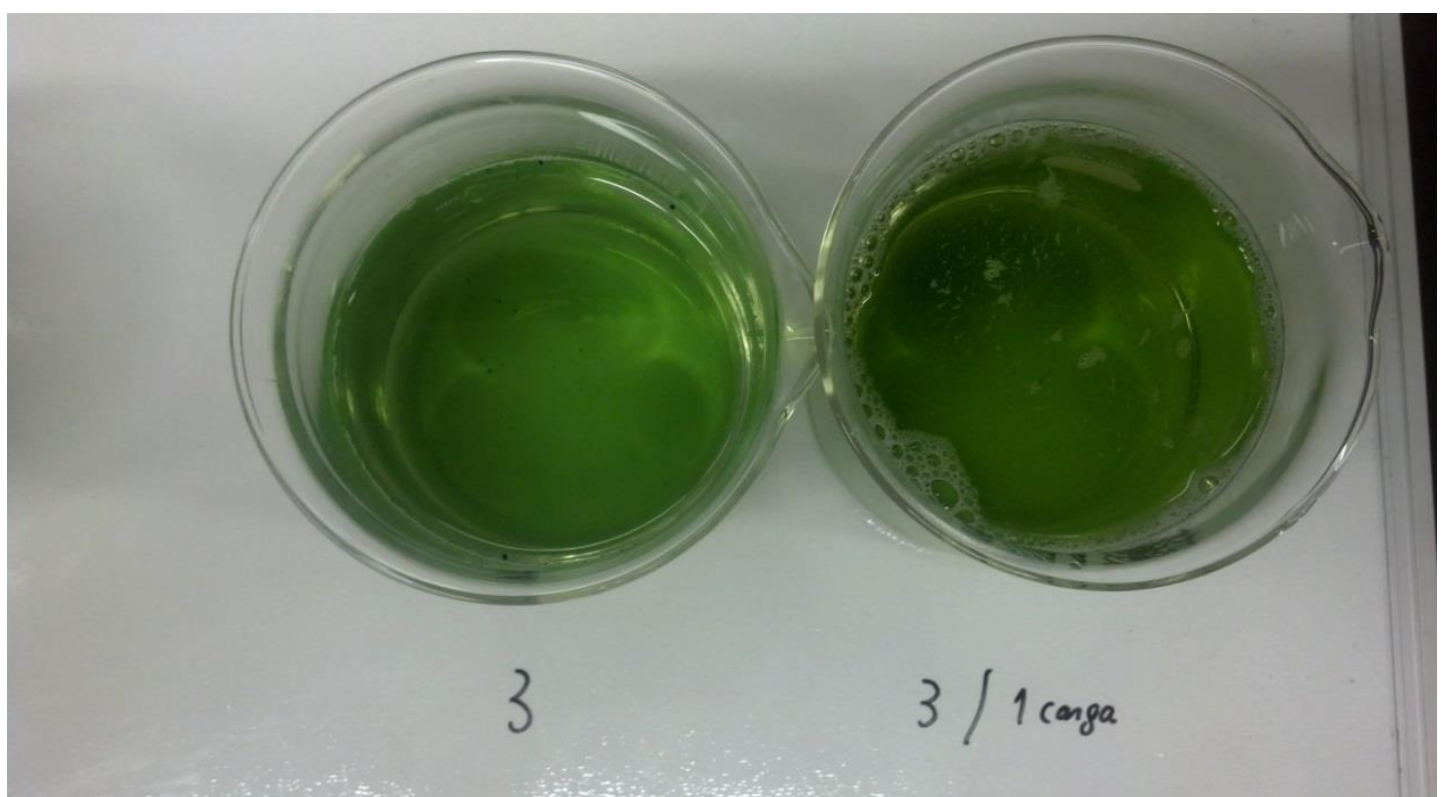

Figura 50: Visão superior do béquer com a adição de 1 carga de urina.

Em todos os casos observou-se um escurecimento da solução de urina e uma natural formação de espumas. A TAB. 15 apresenta os resultados deste teste. 
Tabela 15: Resultados dos testes com as fórmulas FM1, FM2 e FM3 e uma adição de carga de urina em cada caso.

\begin{tabular}{|l|c|c|c|c|c|c|c|}
\hline Parâmetro & Unidade & FM 1 & FM 2 & FM 3 & $\begin{array}{c}\text { FM 1 } \\
\text { 1 carga }\end{array}$ & $\begin{array}{c}\text { FM 2 } \\
\text { carga }\end{array}$ & $\begin{array}{c}\text { FM 3 } \\
\text { 1 carga }\end{array}$ \\
\hline Amônia & $\mathrm{mg} / \mathrm{L} \mathrm{de} \mathrm{NH3}$ & 119,50 & 136,50 & 153,00 & 286,50 & 321,50 & 210,00 \\
\hline N-Amoniacal & $\mathrm{mg} / \mathrm{L} \mathrm{de} \mathrm{N}$ & 97,99 & 111,93 & 125,46 & 234,93 & 263,63 & 172,20 \\
\hline Cor & $\mathrm{mg} / \mathrm{L}$ de PtCo & 304 & 325 & 303 & 443 & 445 & 720 \\
\hline Turbidez & UNT & 2,8 & 3,0 & 2,9 & 4,6 & 4,5 & 3,5 \\
\hline pH & - & 5,9 & 6,5 & 6,8 & 5,9 & 6,2 & 6,4 \\
\hline Cloro Livre & $\mathrm{mg} / \mathrm{L} \mathrm{de} \mathrm{Cl}$ & 0,00 & 0,00 & $<0,01$ & $<0,01$ & $<0,01$ & $<0,01$ \\
\hline Cloro Total & $\mathrm{mg} / \mathrm{L} \mathrm{de} \mathrm{Cl}$ & 7,4 & 1,4 & 0,30 & $<0,01$ & $<0,01$ & $<0,01$ \\
\hline DQO & $\mathrm{mg} / \mathrm{L} \mathrm{de} \mathrm{O}_{2}$ & 2035 & 1970 & 1950 & 3186 & 3155 & 2470 \\
\hline
\end{tabular}

\subsubsection{Testes sensoriais com 10 famílias}

As formulações escolhidas para este teste foram a FM1, FM2 e FM3 (teste anterior) justamente por apresentarem resultados mais baixos de alguns parâmetros como amônia, cor e turbidez. A metodologia aplicada nesta avaliação foi apresentada no item 5.5.

O modelo da ficha de avaliação disponibilizada às famílias pode ser visualizada no apêndice 2. Na ficha de avaliação sensorial há uma pergunta a respeito de qual item o entrevistado julga mais importante. Os atributos organolépticos são: cor, odor, espuma, transparência e presença de sólidos.

A média das respostas das 10 famílias, em ordem de importância, considerou a seguinte proporção: cor: 40\%; odor: 30\%; espuma: 15\%; transparência: 10\% e presença de sólidos: 5\%. Esses valores são fundamentais para atribuir importância às notas em cada característica a fim de se chegar a nota final (total geral).

Os resultados destes testes estão descritos nas TAB. 16 a 18. 
Tabela 16: Resultados dos testes com a formula FM1 (teste com 10 famílias).

\begin{tabular}{|c|c|c|c|c|c|c|c|}
\hline \multirow[b]{2}{*}{ Características } & \multirow{2}{*}{$\begin{array}{l}\text { Peso do } \\
\text { atributo }\end{array}$} & \multicolumn{6}{|c|}{ Notas } \\
\hline & & $\begin{array}{c}\text { Ótimo } \\
\text { (9 a 10) }\end{array}$ & $\begin{array}{c}\text { Muito bom } \\
(7 \text { a } 8)\end{array}$ & $\begin{array}{l}\text { Bom } \\
\text { (5 a } 6)\end{array}$ & $\begin{array}{c}\text { Ruim } \\
\text { (3 a 4) }\end{array}$ & $\begin{array}{c}\text { Péssimo } \\
(0 \text { a } 2)\end{array}$ & $\begin{array}{l}\text { Total } \\
\text { Geral }\end{array}$ \\
\hline Cor & $40 \%$ & $8^{10}$ & $2^{8}$ & - & - & - & \\
\hline Odor & $30 \%$ & $9^{10}$ & $1^{8}$ & - & - & - & \\
\hline Espuma & $15 \%$ & $6^{10}$ & $2^{8}$ & $2^{6}$ & - & - & 94,9 \\
\hline Transparência & $10 \%$ & $6^{10}$ & $3^{8}$ & $1^{6}$ & - & - & \\
\hline Sólidos & $5 \%$ & $9^{10}$ & $1^{8}$ & - & - & - & \\
\hline
\end{tabular}

Tabela 17: Resultados dos testes com a formula FM2 (teste com 10 famílias).

\begin{tabular}{|c|c|c|c|c|c|c|c|}
\hline \multirow[b]{2}{*}{ Características } & \multirow[b]{2}{*}{$\begin{array}{l}\text { Peso do } \\
\text { atributo }\end{array}$} & \multicolumn{6}{|c|}{ Notas } \\
\hline & & $\begin{array}{c}\text { Ótimo } \\
(9 \text { a 10) }\end{array}$ & $\begin{array}{c}\text { Muito } \\
\text { bom } \\
(7 \text { a } 8)\end{array}$ & $\begin{array}{l}\text { Bom } \\
(5 \text { a } 6)\end{array}$ & $\begin{array}{l}\text { Ruim } \\
(3 \text { a } 4)\end{array}$ & $\begin{array}{c}\text { Péssimo } \\
\left(\begin{array}{l}0 \text { a } 2)\end{array}\right.\end{array}$ & $\begin{array}{l}\text { Total } \\
\text { Geral }\end{array}$ \\
\hline Cor & $40 \%$ & $6^{10}$ & $4^{8}$ & - & - & - & \multirow{5}{*}{91,3} \\
\hline Odor & $30 \%$ & $7^{10}$ & $1^{7}, 1^{8}$ & $1^{6}$ & - & - & \\
\hline Espuma & $15 \%$ & $6^{10}$ & $2^{8}$ & $2^{6}$ & - & - & \\
\hline Transparência & $10 \%$ & $6^{10}, 1^{9}$ & $2^{8}$ & $1^{6}$ & - & - & \\
\hline Sólidos & $5 \%$ & $9^{10}$ & $1^{8}$ & - & - & - & \\
\hline
\end{tabular}

Tabela 18: Resultados dos testes com a formula FM3 (teste com 10 famílias).

\begin{tabular}{|c|c|c|c|c|c|c|c|}
\hline \multirow[b]{2}{*}{ Características } & \multirow{2}{*}{$\begin{array}{l}\text { Peso do } \\
\text { atributo }\end{array}$} & \multicolumn{6}{|c|}{ Notas } \\
\hline & & $\begin{array}{c}\text { Ótimo } \\
\text { (9 a 10) }\end{array}$ & $\begin{array}{c}\text { Muito bom } \\
\quad(7 \text { a } 8)\end{array}$ & $\begin{array}{c}\text { Bom } \\
(5 \text { a } 6)\end{array}$ & $\begin{array}{l}\text { Ruim } \\
\text { (3 a 4) }\end{array}$ & $\begin{array}{c}\text { Péssimo } \\
(0 \text { a 2) }\end{array}$ & $\begin{array}{l}\text { Total } \\
\text { Geral }\end{array}$ \\
\hline Cor & $40 \%$ & $5^{10}$ & $3^{8}$ & $2^{6}$ & - & - & \multirow{5}{*}{90,4} \\
\hline Odor & $30 \%$ & $8^{10}$ & $1^{8}$ & $1^{6}$ & - & - & \\
\hline Espuma & $15 \%$ & $7^{10}$ & $2^{8}$ & $1^{6}$ & - & - & \\
\hline Transparência & $10 \%$ & $6^{10}$ & $3^{8}$ & $1^{6}$ & - & - & \\
\hline Sólidos & $5 \%$ & $10^{10}$ & - & - & - & - & \\
\hline
\end{tabular}

Os voluntários tinham a opção de 2 pontuações em cada item de votação, por exemplo, quando se observou o valor " $5^{10 "}$ no campo "ótimo" para o atributo "cor", isso significa que 5 pessoas atribuíram a nota 10 para o item cor. Em outro exemplo têm-se os valores " $6{ }^{10}, 1^{9 "}$, o que pode ser entendido como 6 pessoas que conferiram a nota 10 ao item, e 1 pessoa que votou com a nota 9 . 
Após os testes observou-se que a FM1 foi a que apresentou a resposta mais satisfatória para público avaliado.

Na FIG. 51 pode-se observar um exemplo da forma como o teste foi realizado.
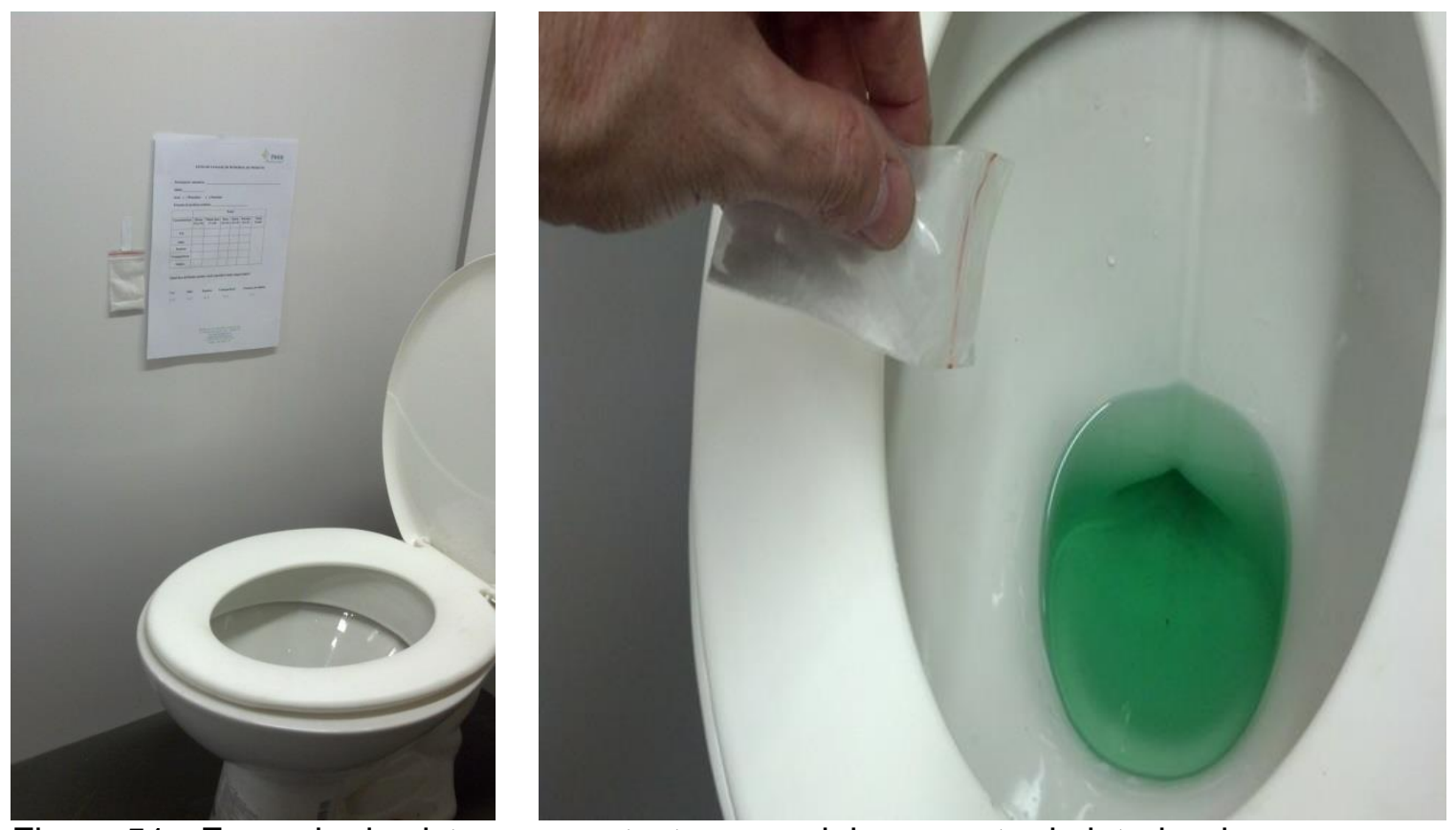

Figura 51: Exemplo do sistema para teste sensorial e aspecto do interior do vaso sanitário após a adição do produto.

\subsubsection{Testes com produtos a base de cloro disponíveis no} mercado.

Em pesquisa recente sobre os produtos clorados mais comuns utilizados no dia a dia com finalidade de limpeza e desinfecção, relacionou-se 3 deles. Na FIG. 52 identificam-se os produtos, cada qual com uma concentração de cloro indicada nos béqueres contendo solução de urina pronta para receber o produto. Entre estes, o que possui maior teor de cloro ativo, na forma de hipoclorito, é o número 1. 


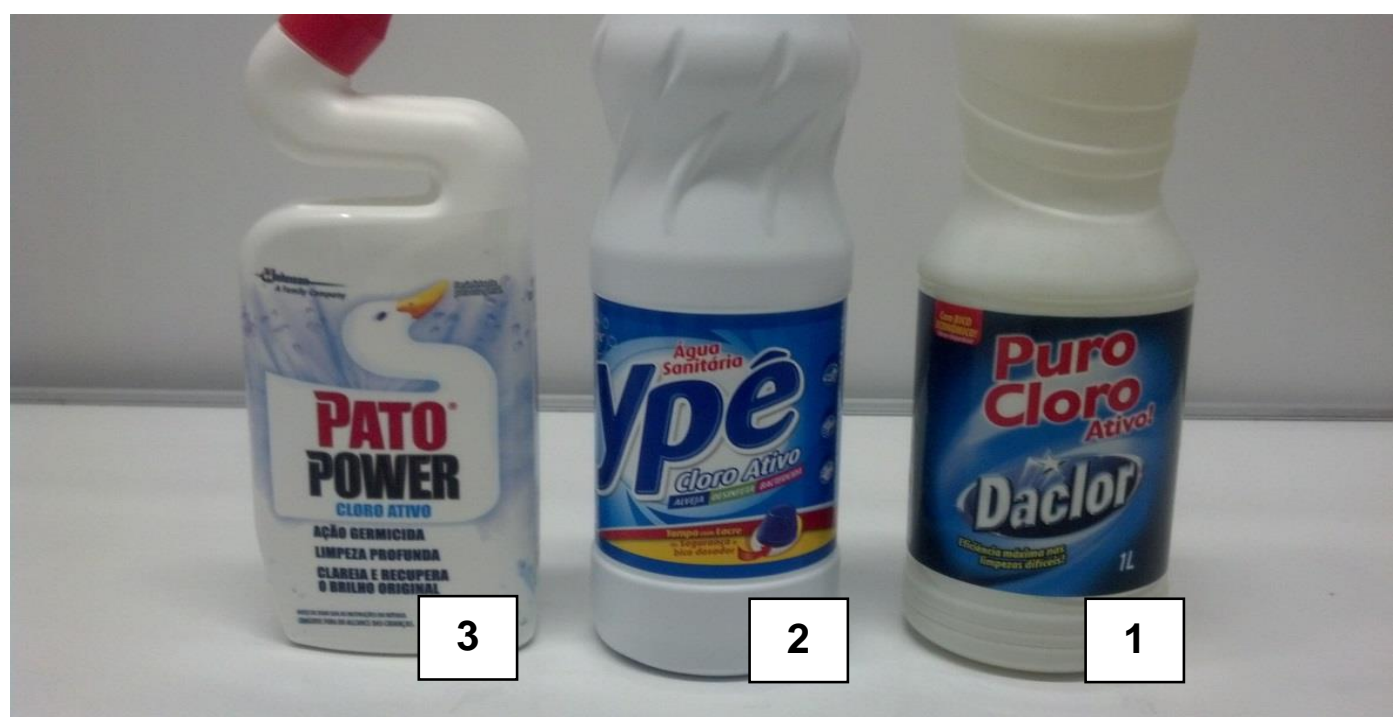

Figura 52: Produtos a base de cloro disponíveis em mercados.

Na FIG. 53 são apresentados os béqueres contendo urina diluída após 5 minutos da adição dos produtos. A quantidade adicionada em cada béquer respeitou as indicações dos rótulos dos produtos para aplicação em vaso sanitário. No caso do produto 3, por exemplo, pede-se para aplicar o produto diretamente no vaso sanitário em toda sua extensão com o bico dosador voltado para a saída de água. Simulou-se essa situação e a massa, neste caso, foi de $15 \mathrm{~g}$ do produto.

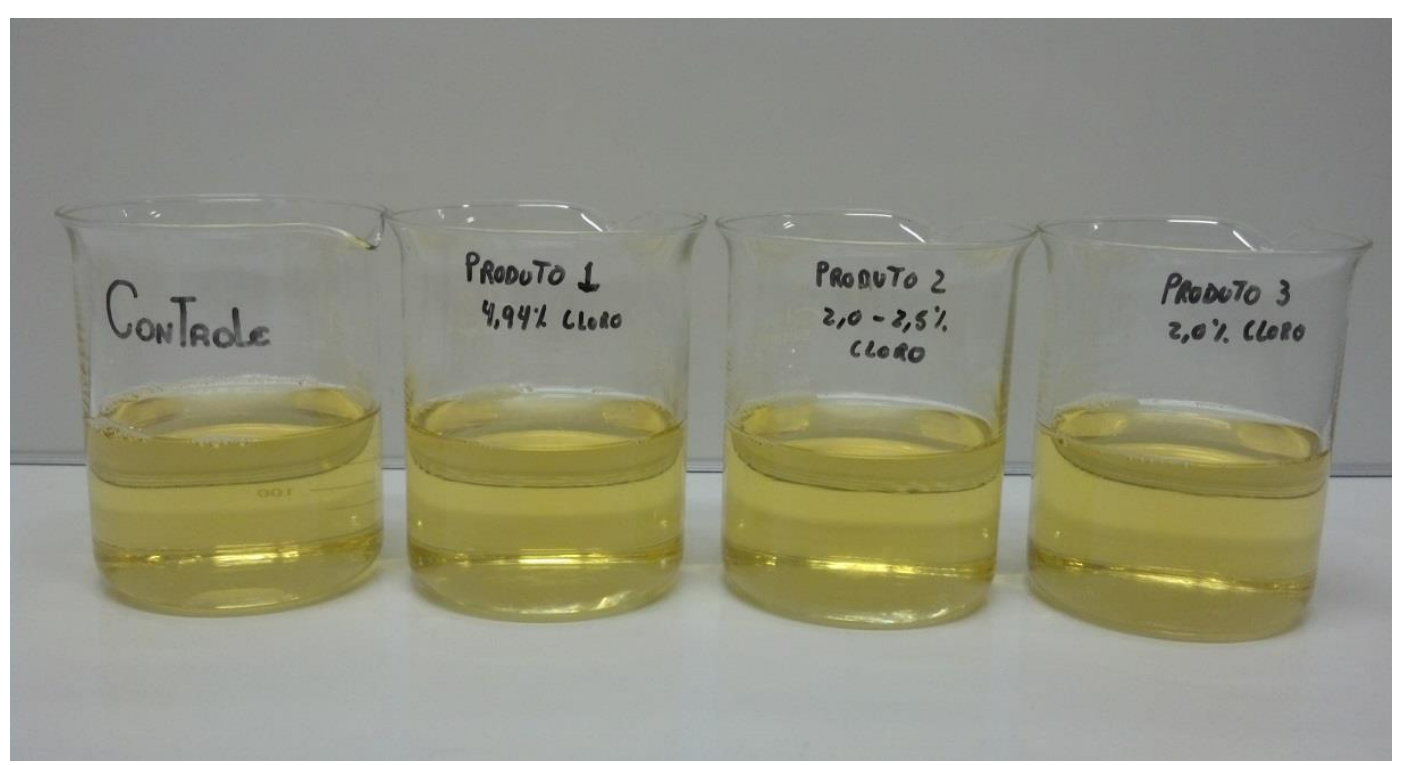

Figura 53: Imagem dos produtos e dos béqueres contendo urina diluída para teste. 
A TAB. 19 apresenta os resultados dos testes realizados com os três produtos.

Tabela 19: Resultados dos testes com os 3 produtos disponível no mercado.

\begin{tabular}{|l|c|c|c|c|c|}
\hline Parâmetro & Unidade & Controle & Produto1 & Produto2 & Produto3 \\
\hline Amônia & $\mathrm{mg} / \mathrm{L} \mathrm{de} \mathrm{NH}_{3}$ & 176,40 & 149,00 & 161,00 & 172,00 \\
\hline $\mathbf{p H}$ & - & 5,73 & 5,71 & 5,74 & 5,90 \\
\hline Cloro Livre & $\mathrm{mg} / \mathrm{L} \mathrm{de} \mathrm{Cl}$ & 0,10 & 0,20 & 0,10 & 0,2 \\
\hline Cloro Total & $\mathrm{mg} / \mathrm{L} \mathrm{de} \mathrm{Cl}$ & 0,10 & 3,10 & 2,20 & 0,20 \\
\hline Cloroaminas & $\mathrm{mg} / \mathrm{L}$ & $<0,10$ & 2,90 & 2,00 & $<0,10$ \\
\hline Monocloroaminas & $\mathrm{mg} / \mathrm{L} \mathrm{de} \mathrm{Cl}$ & 0,10 & 0,60 & 0,30 & 0,10 \\
\hline
\end{tabular}

Pelos resultados apresentados, nota-se que estes produtos são pouco eficientes para a eliminação de amônia em comparação ao produto Dicloroisocianurato de sódio ( $\mathrm{NaDCC}$ ). As massas adicionadas destes produtos em comparação ao cloro orgânico ( $\mathrm{NaDCC})$ foram cerca de 100 vezes maior.

\subsection{Testes de reatividade biológica}

A avaliação do produto no tocante à reatividade biológica, ação antimicrobiana, ação bactericida e o estudo da citotoxicidade das substâncias é de relevante importância para o conhecimento da dosagem correta dos componentes na formulação, e das eventuais interações nocivas pelo uso do produto em diferentes situações de aplicação e concentração no meio reacional.

Desta maneira foram testadas 2 formulações escolhidas em função da composição de melhor desempenho analítico e sensorial. Na formulação FM1 foi possível observar o comportamento do componente principal isolado (Dicloroisocianurato de Sódio) apenas em associação com o corante, composto coadjuvante comprovadamente inerte diante dos testes anteriormente realizados.

Já na formula FM2 avaliou-se uma composição que reuniu todos os compostos coadjuvantes em associação ao Dicloroisocianurato de Sódio. Os resultados para ambas podem ser observados na TAB. 20 . 
Tabela 20: Formulações para análises de reatividade biológica

\begin{tabular}{lcc}
\hline Componentes & FM 1 & FM 2 \\
\hline $\mathrm{NaDCC}$ & $1,00 \mathrm{~g}$ & $1,00 \mathrm{~g}$ \\
$\mathrm{NaHCO}_{3}$ & - & $0,50 \mathrm{~g}$ \\
Amido & - & $0,60 \mathrm{~g}$ \\
Essência & - & $0,10 \mathrm{~g}$ \\
Corante verde & $0,01 \mathrm{~g}$ & $0,01 \mathrm{~g}$ \\
Antiespumante & - & $0,10 \mathrm{~g}$ \\
\hline Total & $1,01 \mathrm{~g}$ & $2,31 \mathrm{~g}$ \\
\hline
\end{tabular}

\subsection{Análise de Citotoxicidade}

Neste teste foram usadas duas substâncias de referência, uma para controle negativo (284CN): pellets de PEAD (polietileno de alta densidade) e outra para positivo (284CP): luvas de látex natural. Em cada caso foi pesado cerca de 800 mg de amostra e preparado um extrato na concentração de 200 mg/L.

\subsubsection{Aplicação e preparação da substância teste}

Preparação: foram pesados 0,0050 g da substância teste FM1 e FM2. Em seguida foram adicionados $10 \mathrm{~mL}$ de meio de cultura para cada substância teste. A esterilização foi realizada por filtração em filtro de seringa.

A partir da concentração de $0,5 \mathrm{mg} / \mathrm{mL}(100 \%)$ foram preparadas as concentrações: 0,003\%, 0,03\%, 0,3\%, 3\%, 10\% e 32\%.

\subsubsection{Preparação do sistema teste}

Para a condução deste teste utilizou-se as células de ovário de hamster chinês da linhagem CHO-K1 (ATCC CCL-61). As células foram mantidas em cultura até serem utilizadas no teste.

$\mathrm{Na}$ TAB. 21 estão apresentados os valores de viabilidade celular e do desvio padrão encontrados para substâncias de referência e para a substância teste. 
Tabela 21: Valores de viabilidade celular obtidos para cada concentração dos extratos das substâncias de referência e da substância-teste.

\begin{tabular}{|c|c|c|c|c|c|c|c|}
\hline Concentração do extrato (\%) & 6,25 & 12,5 & 25 & 50 & 100 & - & - \\
\hline \multicolumn{8}{|c|}{ 284CN - PEAD } \\
\hline Viabilidade Celular (\%) & 102,7 & 101,7 & 102,4 & 100,7 & 101.9 & - & - \\
\hline Desvio Padrão & 3,7 & 4,5 & 8,3 & 6,3 & 5,9 & - & - \\
\hline \multicolumn{8}{|c|}{ 284CP - Luva de Látex natural } \\
\hline Viabilidade Celular (\%) & 0 & 0 & 1,3 & 0,9 & 2,8 & - & - \\
\hline Desvio Padrão & 0,028 & 0,025 & 0,045 & 0,032 & 0,015 & - & - \\
\hline Concentração do extrato (\%) & 0,003 & 0,03 & 0,3 & 3 & 10 & 32 & 100 \\
\hline \multicolumn{8}{|c|}{ Substância teste FM1 } \\
\hline Viabilidade Celular (\%) & 98,5 & 99,6 & 102,6 & 102,7 & 102,3 & 65 & 2,2 \\
\hline Desvio Padrão & 1,7 & 2,3 & 3,6 & 4,5 & 1,7 & 12,8 & 3,6 \\
\hline \multicolumn{8}{|c|}{ Substância teste FM2 } \\
\hline Viabilidade Celular (\%) & 102,9 & 99,6 & 104,1 & 106,6 & 107,9 & 99,7 & 1,6 \\
\hline Desvio Padrão & 4,8 & 3,6 & 5,2 & 5,2 & 4,8 & 6,4 & 3,6 \\
\hline
\end{tabular}

Na FIG. 54 é possível observar o gráfico da porcentagem (\%) de viabilidade celular das substâncias de referência.

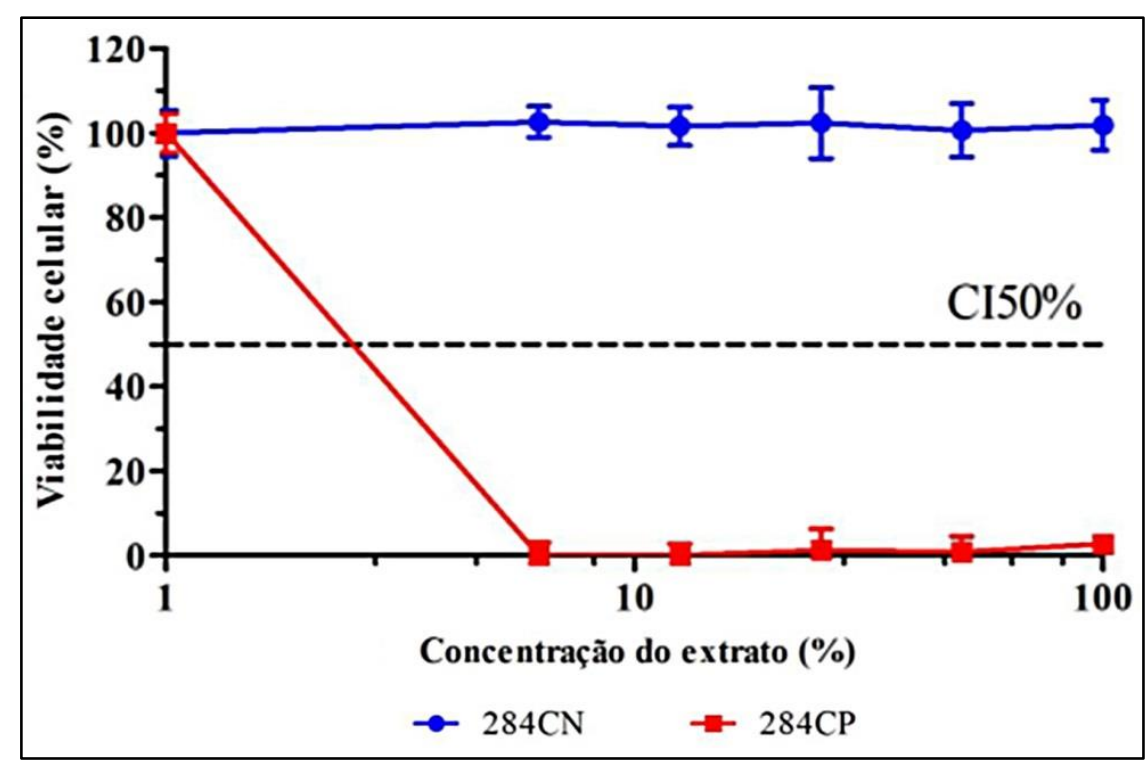

Figura 54: Porcentagem de viabilidade celular das substâncias de referência $284 \mathrm{CN}$ (controle negativo) e 284CP (controle positivo). 
Na FIG. 55 é possível observar o gráfico da porcentagem (\%) de viabilidade celular das substâncias teste FM1 e FM2.

Para as concentrações testadas, o valor de $\mathrm{Cl} 50 \%$ para a substância teste FM1 corresponde a $51,76 \%$ e para a substância teste FM2 58,88\%.

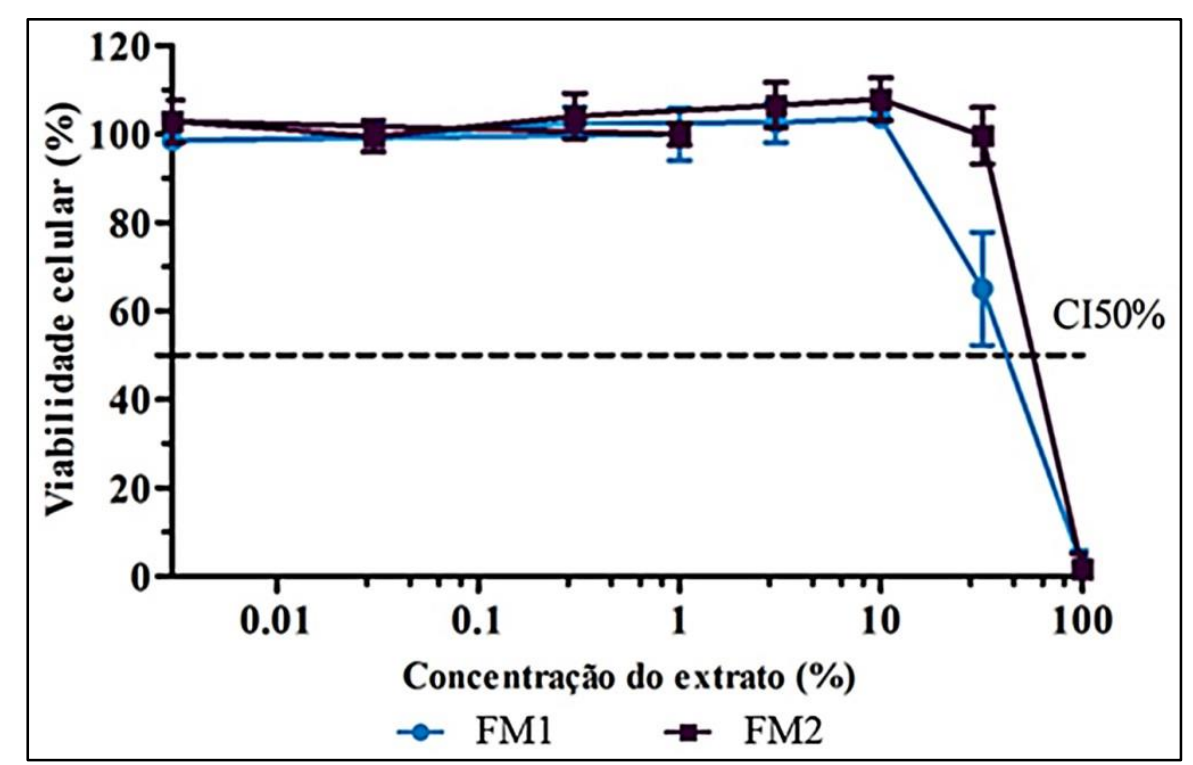

Figura 55: Porcentagem de viabilidade celular das substâncias teste FM1 e FM2.

$\mathrm{Na}$ FIG. 56 verifica-se que, as células $\mathrm{CHO}-\mathrm{K} 1$ após a exposição à substância teste FM1 na concentração de 0,003\% (FIG. 56D) não apresentaram alteração na morfologia, quando comparadas as células antes da exposição (FIG. 56C) e ao controle de células antes e após a exposição (FIG. 56A e 56B) à substância teste.

Contrariamente, as células que foram expostas à substância teste FM1 na concentração de 100\% (FIG. 56F) apresentaram alteração na morfologia quando comparadas as células antes da exposição (FIG. 56E). 


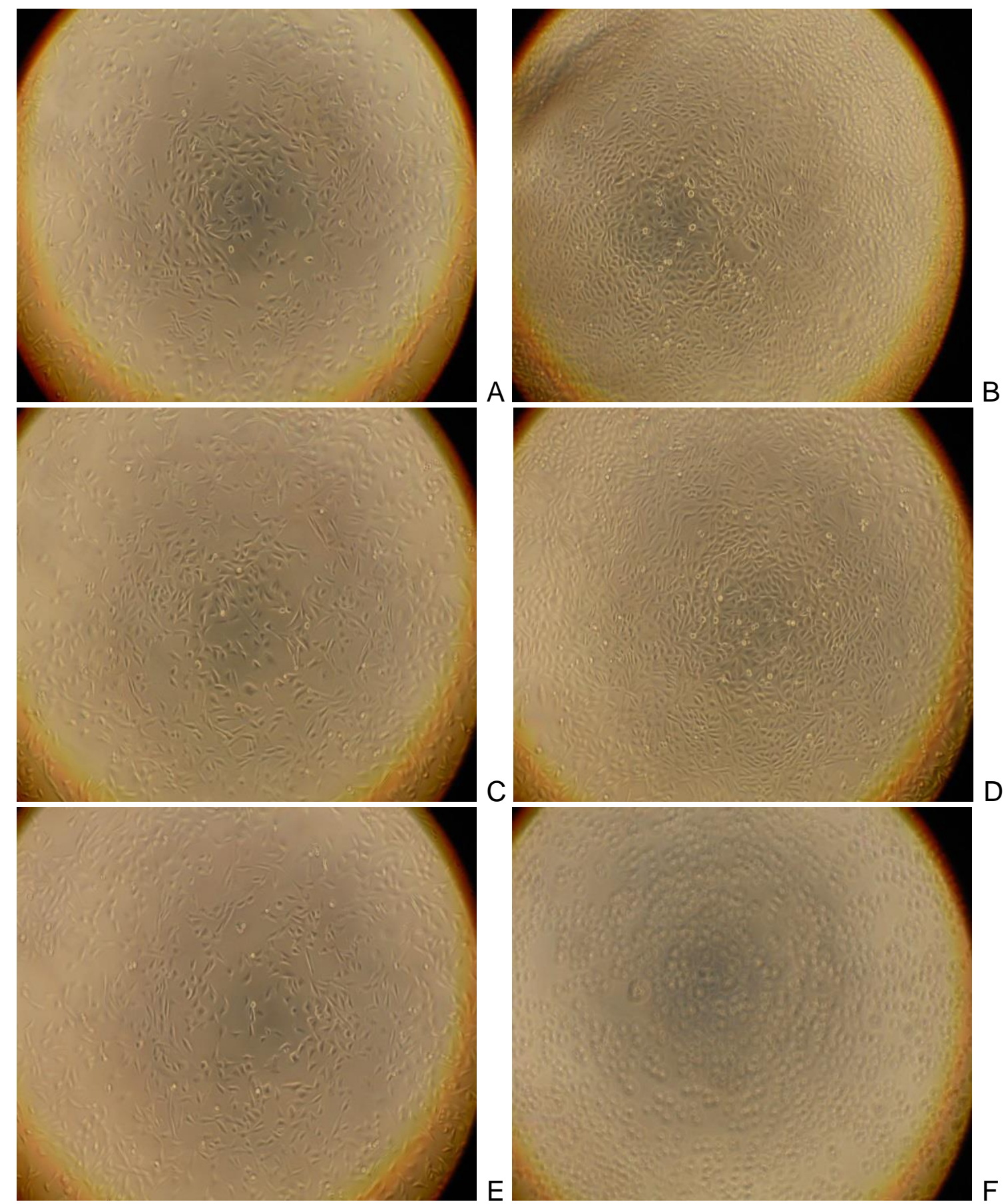

Figura 56: Fotomicrografia das células $\mathrm{CHO}-\mathrm{K} 1$ expostas à substância teste FM1 .

\begin{tabular}{|c|c|}
\hline Legenda: & $\begin{array}{l}\text { controle de células antes da exposição à substância teste }(A) \text {; controle de células após a } \\
\text { exposição à substância teste (B); células antes da exposição à substância teste FM1 na } \\
\text { concentração de } 0,003 \% \text { (C); células após a exposição à substância teste FM1 na } \\
\text { concentração de } 0,003 \% \text { (D); células antes da exposição à substância teste FM1 na } \\
\text { concentração de } 100 \% \text { (E); células após a exposição à substância teste FM1 na concentração }\end{array}$ \\
\hline
\end{tabular}


$\mathrm{Na}$ FIG. 57 verifica-se que, as células CHO-K1 após a exposição à substância teste FM2 na concentração de 0,003\% (FIG. 57D) não apresentaram alteração na morfologia, quando comparadas as células antes da exposição (FIG. $57 \mathrm{C}$ ) e ao controle de células antes e após a exposição (FIG. 57A e 57B) à substância teste.

Contrariamente, as células que foram expostas à substância teste FM2 na concentração de 100\% (FIG. 57F) apresentaram alteração na morfologia quando comparadas as células antes da exposição (FIG. 57E). 


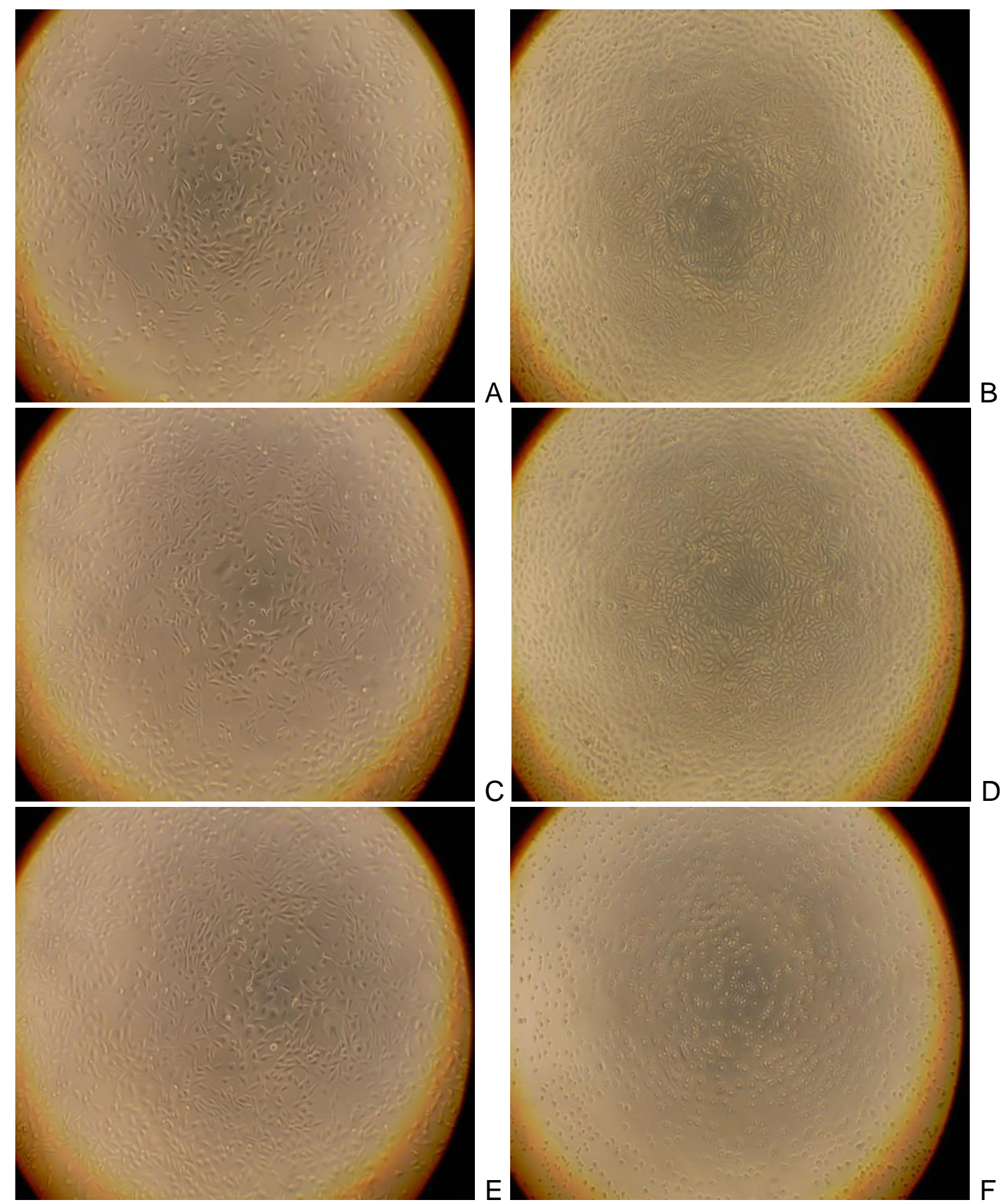

Figura 57: Fotomicrografia das células $\mathrm{CHO}-\mathrm{K} 1$ expostas à substância teste FM2.
Legenda: $\quad$ controle de células antes da exposição à substância teste $(A)$; controle de células após a exposição à substância teste (B); células antes da exposição à substância teste FM2 na concentração de $0,003 \%$ (C); células após a exposição à substância teste FM2 na concentração de $0,003 \%$ (D); células antes da exposição à substância teste FM2 na concentração de 100\% (E); células após a exposição à substância teste FM2 na concentração de $100 \%(F)$.


$\mathrm{Na}$ FIG. 58 verifica-se que, as células $\mathrm{CHO}-\mathrm{K} 1$ após a exposição à substância de referência $284 \mathrm{CN}$ na concentração de 6,25\% (FIG. 58D) não apresentaram alteração na morfologia, quando comparadas as células antes da exposição (FIG. 58C) e ao controle de células antes e após a exposição (FIG. 58A e 64B) substância de referência $284 \mathrm{CN}$.

Assim como, as células que foram expostas à substância de referência $284 \mathrm{CN}$ na concentração de $100 \%$ (FIG. 58F) não apresentaram alteração na morfologia quando comparadas as células antes da exposição (FIG. 58E). 


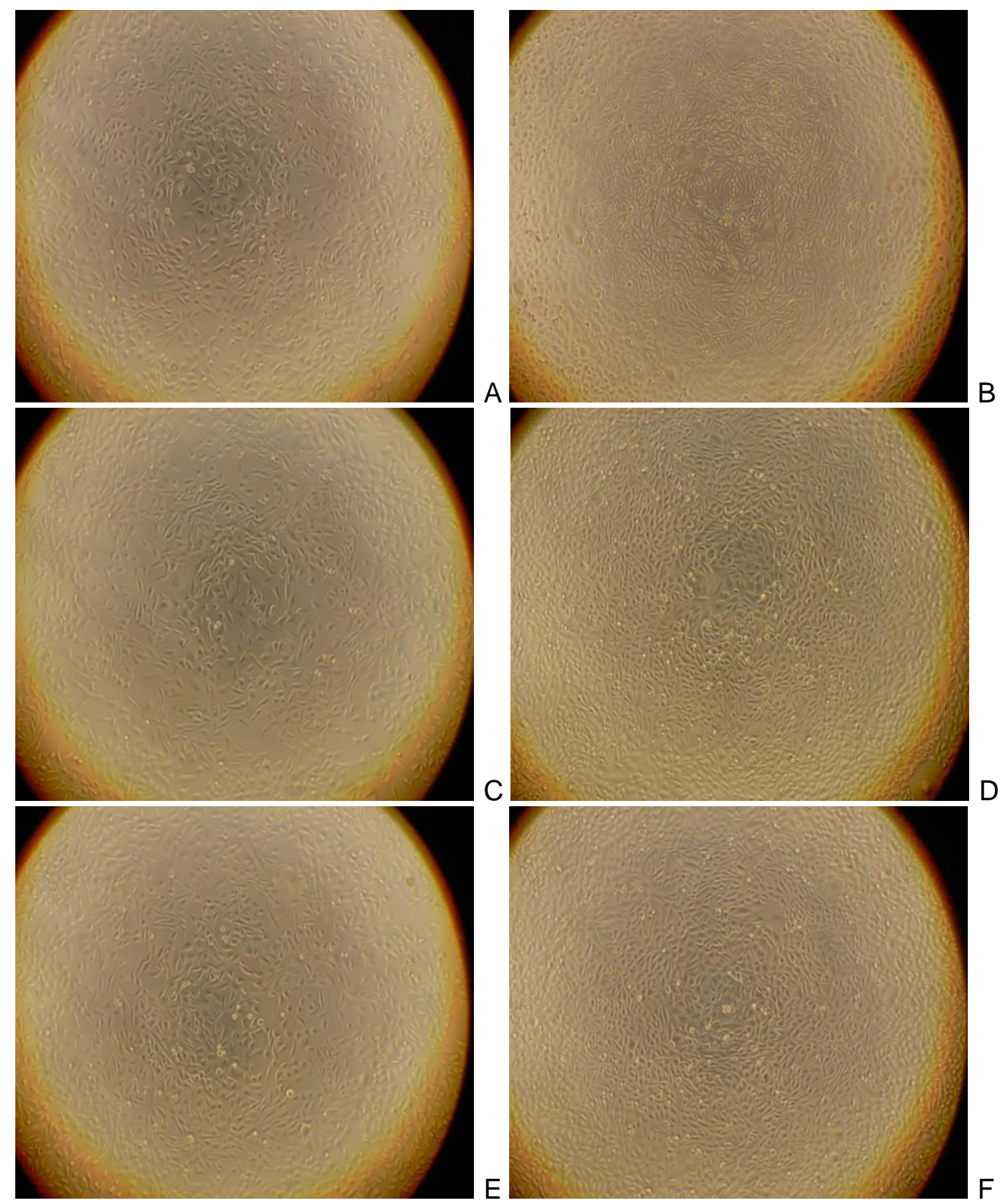

Figura 58: Fotomicrografia das células $\mathrm{CHO}-\mathrm{K} 1$ expostas à substância de referência $284 \mathrm{CN}$.

$\begin{array}{ll}\text { Legenda: } & \text { controle de células antes da exposição à substância de referência (A); controle de células após } \\ & \text { a exposição à substância de referência } 284 \mathrm{CN} \text { (B); células antes da exposição à substância de } \\ & \text { referência } 284 \mathrm{CN} \text { na concentração de } 6,25 \% \text { (C); células após a exposição à substância de } \\ & \text { referência } 284 \mathrm{CN} \text { na concentracão de } 6,25 \% \text { (D); células antes da exposição à substância de } \\ & \text { referência } 284 \mathrm{CN} \text { na concentração de } 100 \% \text { (E); células após a exposição à substância de } \\ & \text { referência } 284 C N \text { na concentração de } 100 \% \text { (F). }\end{array}$


$\mathrm{Na}$ FIG. 59 verifica-se que, as células $\mathrm{CHO}-\mathrm{K} 1$ após a exposição à substância de referência $284 \mathrm{CP}$ na concentração de 6,25\% (FIG. 59D) não apresentaram alteração na morfologia, quando comparadas as células antes da exposição (FIG. 59C) e ao controle de células antes e após a exposição (FIG. 59A e 59B) substância de referência 284CP.

Contrariamente, as células que foram expostas à substância de referência 284CP na concentração de 100\% (FIG. 59F) apresentaram alteração na morfologia quando comparadas as células antes da exposição (FIG. 59E). 

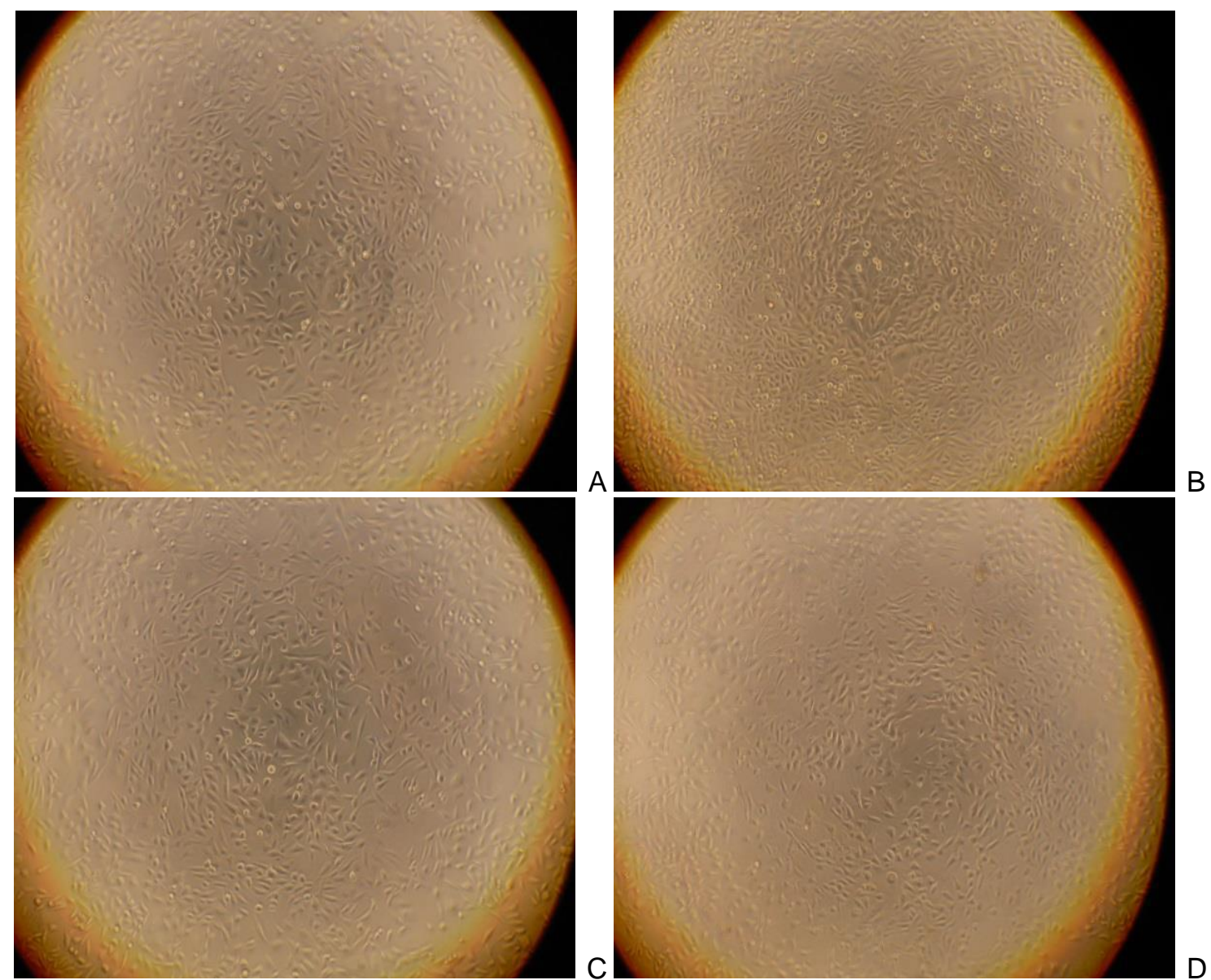

B
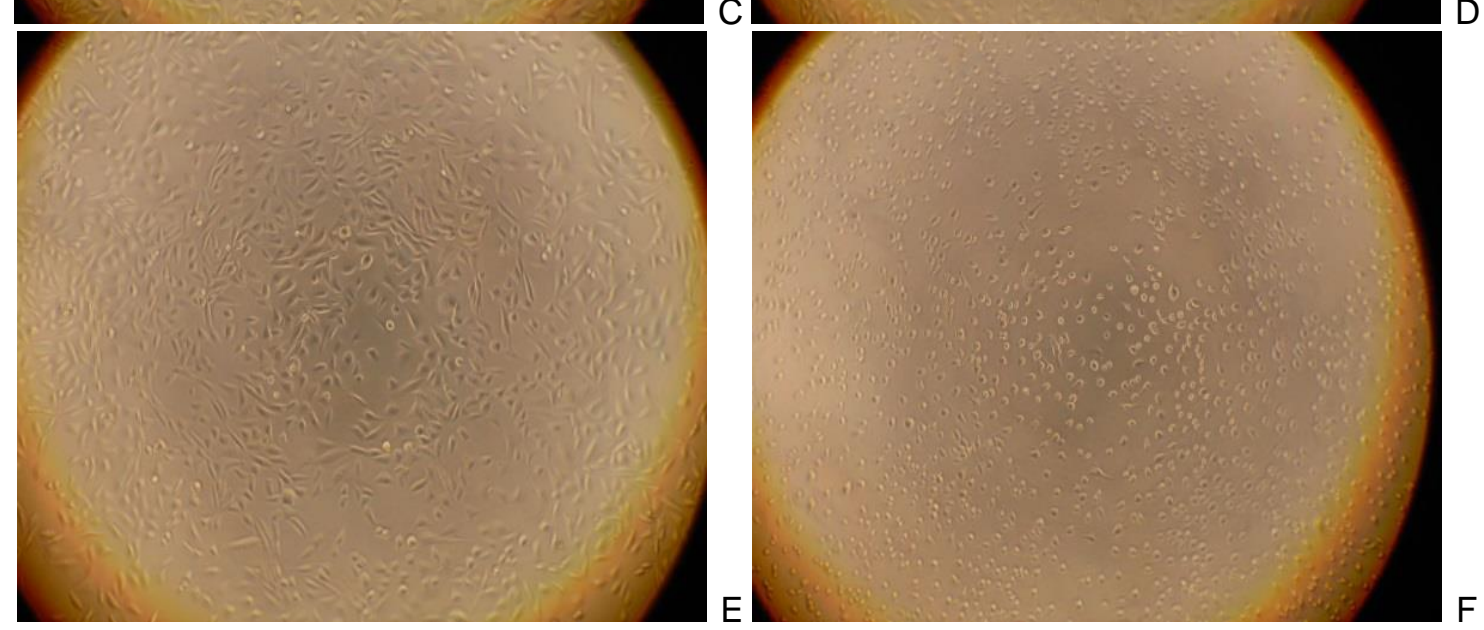

Figura 59: Fotomicrografia das células $\mathrm{CHO}-\mathrm{K} 1$ expostas à substância de referência 284CP.

Legenda: controle de células antes da exposição à substância de referência $(\mathrm{A})$; controle de células após a exposição à substância de referência 284CP (B); células antes da exposição à substância de referência 284CP na concentração de 6,25\% (C); células após a exposição à substância de referência $284 \mathrm{CP}$ na concentração de 6,25\% (D); células antes da exposição à substância de referência 284CP na concentração de 100\% (E); células após a exposição à substância de referência $284 \mathrm{CP}$ na concentração de $100 \%$ (F). 


\subsubsection{Resultados dos testes de Citotoxicidade}

As substâncias teste FM1 e FM2 apresentaram viabilidade celular maior que $50 \%$ nas concentrações de $0,003 \%, 0,03 \%, 0,3 \%, 3 \%, 10 \%$ e $32 \%$.

Os valores de $\mathrm{Cl} 50 \%$ nas concentrações testadas para a substância teste FM1 e FM2 corresponderam respectivamente a $51,76 \%$ e $58,88 \%$.

\subsection{Avaliação da atividade bactericida}

Neste teste foi verificada a eficácia da atividade bactericida do produto frente a alguns micro-organismos

\subsubsection{Aplicação e preparação da sustância teste}

As amostras foram preparadas em água destilada.

\subsubsection{Aplicação e preparação do sistema teste}

Para condução deste teste utilizou-se os seguintes micro-organismos:

- - Escherichia coli (ATCC ํo 8739);

- - Staphylococcus aureus (ATCC № 6538);

- - Pseudomonas aeruginosa (ATCC no 15442);

- - Salmonella choleraesuis (ATCC no 10708).

O teste foi conduzido conforme a metodologia POT 017 - Procedimento INCQS - no 65.3210.007 - Método de diluição de uso.

\subsubsection{Resultados do teste de atividade bactericida}

A TAB. 22 apresenta o número de resultados positivos obtidos para os micro-organismos testados. 
Tabela 22: Número de cilindros com resultados positivos para os micro-organismos testados.

\begin{tabular}{|c|c|c|c|}
\hline Micro-organismo (s) & no ATCC & $\begin{array}{c}n^{\circ} \text { de cilindros } \\
\text { testados }\end{array}$ & $\begin{array}{c}n^{\circ} \text { de cilindros } \\
\text { positivos }\end{array}$ \\
\hline Escherichia coli & 8739 & 60 & 0 \\
\hline Staphylococcus aureus & 6538 & 60 & 0 \\
\hline Pseudomonas aeruginosa & 15442 & 60 & 0 \\
\hline Salmonella choleraesuis & 10708 & 60 & 0 \\
\hline
\end{tabular}

As amostras FM1 e FM2 foram consideradas eficazes frente aos microorganismos testados.

\subsection{Avaliação da atividade Antimicrobiana}

Neste teste foi avaliada a atividade Antimicrobiana - Bacteriostática e Fungistática das amostras.

\subsubsection{Aplicação e preparação das substâncias teste}

Foram pesados 0,8 $\mathrm{g}$ de cada substância teste. Em seguida essas amostras foram acondicionadas em microtubos.

\subsubsection{Aplicação e preparação do sistema teste}

Para a condução deste teste utilizou-se os micro-organismos Pseudomonas aeruginosa (ATCC no 9027) e Escherichia coli (ATCC no 8739).

Foram utilizados os meios de cultura Tryptic Soy Agar e Sabouraud Dextrose Agar, em placa de ágar com orifício.

O método utilizado foi o plaqueamento em superfície. O teste foi conduzido conforme a metodologia INCQS 65.3210.006 - Método para Avaliação das Atividades Bacteriostática e Fungistática de saneantes e substâncias preservativas. 


\subsubsection{Resultados dos testes de Atividade Antimicrobiana}

$\mathrm{Na}$ FIG. 60 verifica-se a o halo de inibição de $39 \mathrm{~mm}$ provocados pela amostra FM1, para o micro-organismo Pseudomonas aeruginosa (FIG. 60A) e Escherichia coli (FIG. 60B).
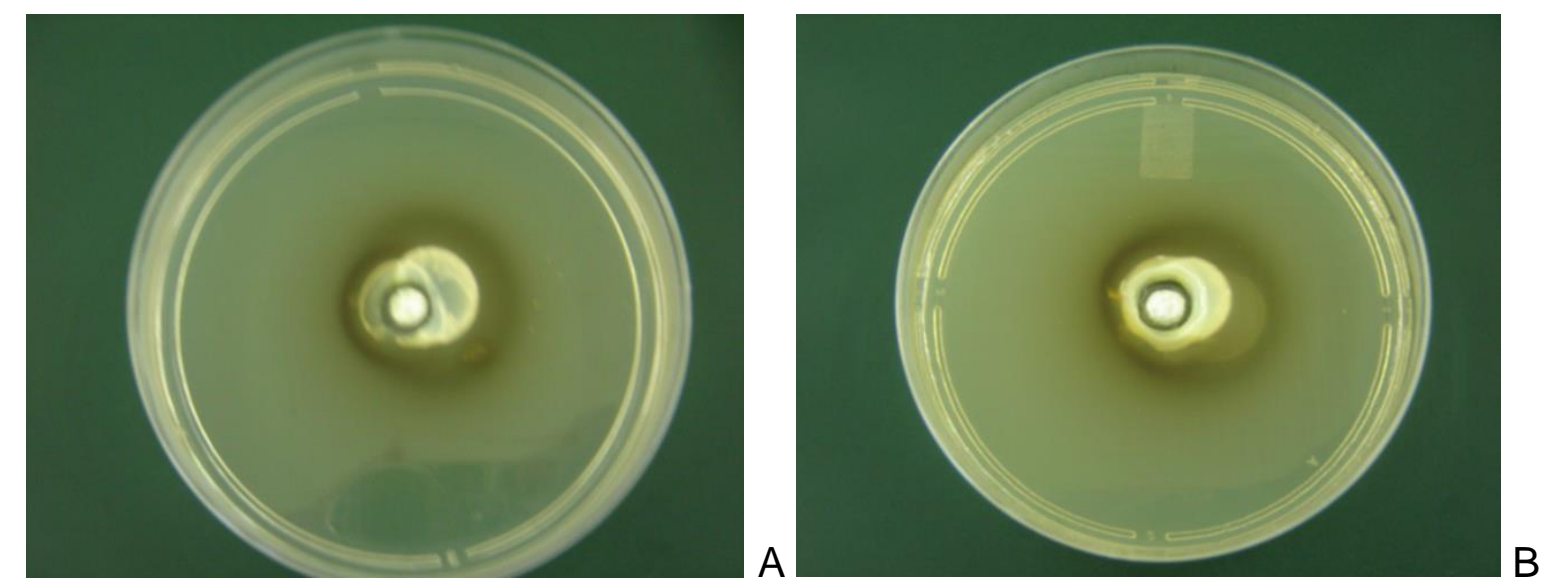

Figura 60: Halo de inibição provocado pela amostra FM1 para os micro-organismos Pseudomonas aeruginosa (67A) e Escherichia coli (67B).

Na FIG. 61 verifica-se a o halo de inibição de $39 \mathrm{~mm}$ provocados pela amostra FM2, para o micro-organismo Pseudomonas aeruginosa (FIG. 61A) e Escherichia coli (FIG. 61B).
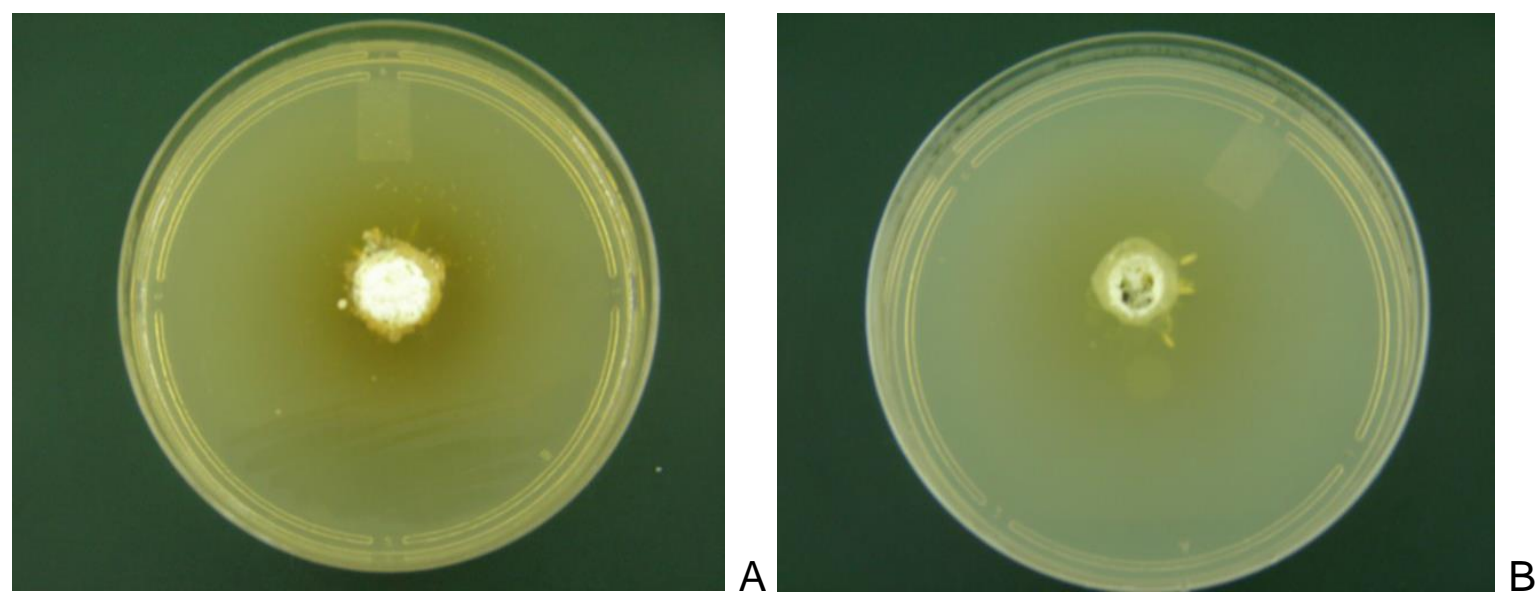

Figura 61: Halo de inibição provocado pela amostra FM2 para os micro-organismos Pseudomonas aeruginosa (68A) e Escherichia coli (68B).

As amostras FM1 e FM2 apresentaram resultados que indicam atividade antimicrobiana frente aos micro-organismos testados. 


\section{CONCLUSÕES}

Os resultados apontam que o Dicloroisocianurato de Sódio, NaDCC, é eficiente para a o tratamento da urina humana em bacias sanitárias, considerando-se os objetivos deste trabalho.

O Planejamento Fatorial realizado indicou que os resultados de concentração de amônia sofrem grande influência da presença do NaDCC, o que já era esperado; no entanto, observou-se que alguns agentes coadjuvantes na fórmula, como por exemplo o antiespumante, contribui para a não diminuição desta concentração, sendo este um ponto negativo ao processo. Sendo assim, para uma melhor combinação da formulação é importante ter em vista uma composição com menor presença deste componente.

Da mesma maneira, observou-se no teste de $\mathrm{pH}$, que o $\mathrm{NaHCO}_{3}$ é o componente mais significativo para alteração do $\mathrm{pH}$ do meio, sendo os demais fatores pouco influentes neste processo. Em uma perspectiva de enquadrar o pH do meio na faixa entre 6 e 9, apontada no Decreto Estadual Paulista (Art. 19A), é possível otimizar a formulação de maneira a adequar o efluente final.

Outros fatores como antiespumante, essência, corante e amido devem ser muito bem observados para o desenvolvimento das formulações, pois afetam diretamente parâmetros importantes como Cloroaminas, Cloro (livre e total) e cor.

As 6 formulações estudadas confirmam, com poucas exceções, os efeitos apresentados no planejamento fatorial, fundamentalmente no que se refere ao uso do produto NaDCC como componente inibidor de amônia no ambiente contendo urina humana, 0 que consequentemente reduz significativamente o odor do meio.

De acordo com os testes realizados, em comparação a outros produtos disponíveis no mercado contendo cloro, o NaDCC mostra-se muito mais eficiente para redução da concentração de amônia em sistemas contendo urina.

A pesquisa realizada mostra que o $\mathrm{NaDCC}$, além se ser eficiente ao objetivo proposto, apresenta como características, em função da praticidade no 
manuseio, medição, transporte e armazenamento; maior solubilidade em água, maior período de validade, menor risco (corrosividade), modernidade do produto (tecnologia de embalagens com uso como produto efervescente) e, sobretudo a menor probabilidade de formação de subprodutos, entre eles os Trihalometanos (THMs), cujo grau de toxidade é altíssimo.

Essas características são vantagens para uso no dia a dia, em residência e/ou indústrias, em processo de desinfecção de água, equipamentos/utensílios, embalagens, ambientes.

Os testes de reatividade biológica indicaram que o produto apresenta viabilidade celular acima de $50 \%$ nas concentrações testadas $(0,003 \%, 0,03 \%$, $3 \%, 10 \%$ e $32 \%$, o que indica uma excelente margem de segurança para trabalhos dentro das formulações apresentadas.

Em relação a atividade bactericida, o produto foi considerado eficaz frente aos micro-organismos Escherichia coli, Pseudomonas Aeruginosa, Salmonella Choleraesuis e Staphylococcus Aureus. Da mesma forma, frente aos micro-organismos Escherichia coli e Pseudomonas Aeruginosa, o produto apresentou atividade antimicrobiana. 


\section{CONSIDERAÇÕES FINAIS/TRABALHOS FUTUROS}

\subsection{Conformação do produto em formato de pastilhas}

A continuidade deste projeto prevê a conformação dos componentes estudados em um formato de pastilhas a ser aplicada diretamente no vaso sanitário, por uma questão de praticidade no manuseio e segurança, esse formato é visto como mais indicado.

Neste caso, entende-se que haverá necessidade de um estudo da cinética de dissolução dos componentes para avaliar o comportamento frente ao meio (solução de urina no vaso sanitário). As FIG. 62 e 63 apresentam um sistema adequando para este estudo.

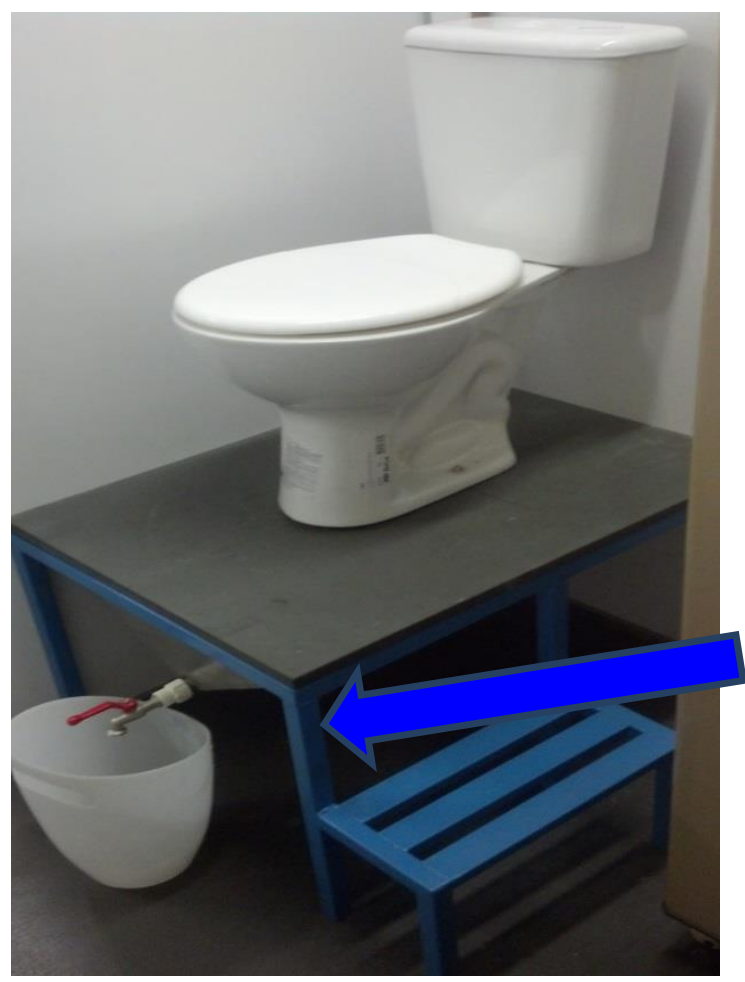

Válvula para coleta de amostras

Figura 62: Sistema de coleta de efluentes do vaso sanitário. 


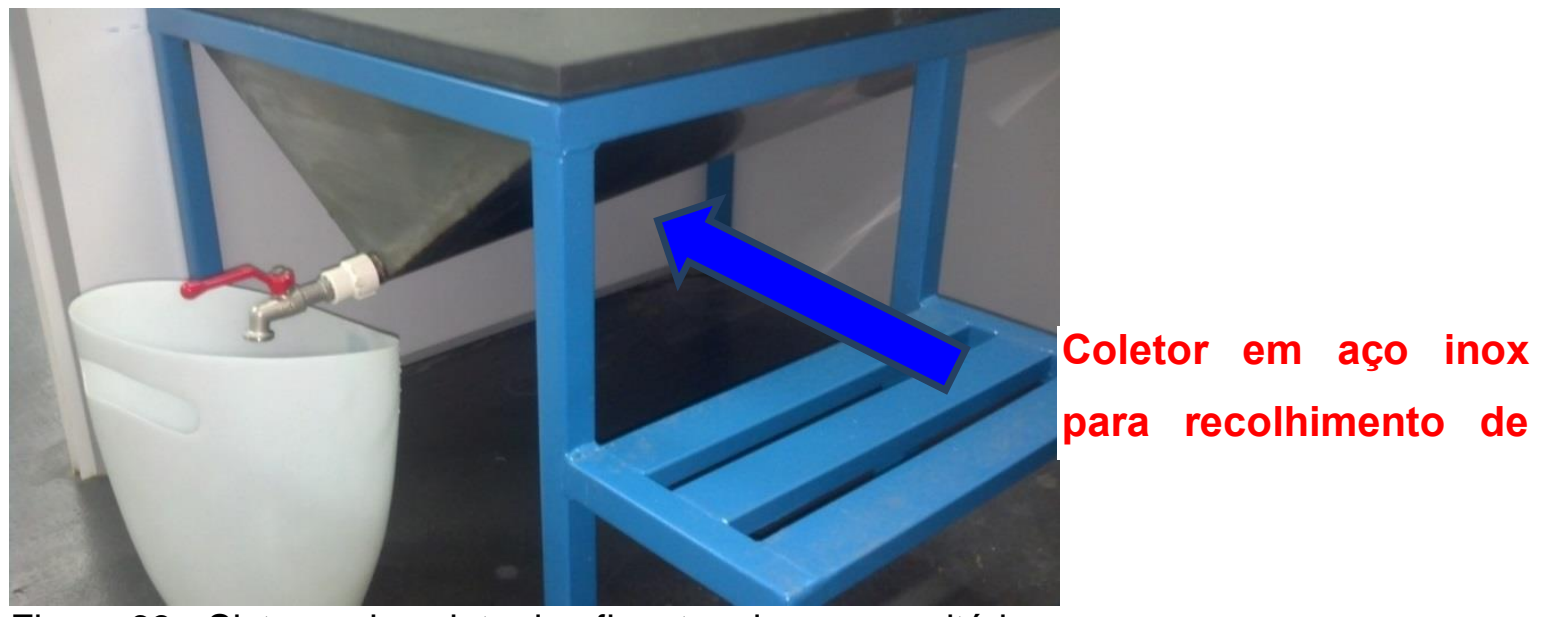

Figura 63: Sistema de coleta de efluentes do vaso sanitário.

Na FIG. 64 é mostrada uma prensa hidráulica para compactação do produto (pó) e formação das pastilhas, como no exemplo da FIG. 65.

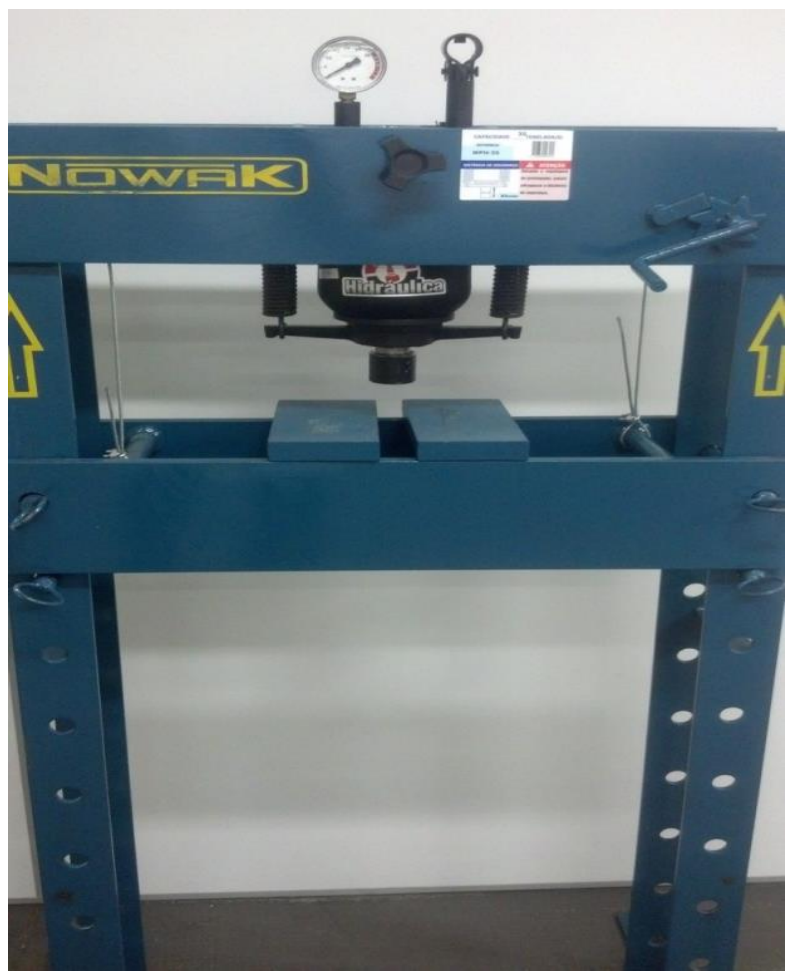

Figura 64: Prensa Hidráulica para compactação das pastilhas.

Considera-se ainda a realização de análises de THMs (Trihalometanos) nas amostras testadas, bem como testes de genotoxicidade do produto isolado (NaDCC) e das formulações desenvolvidas. 


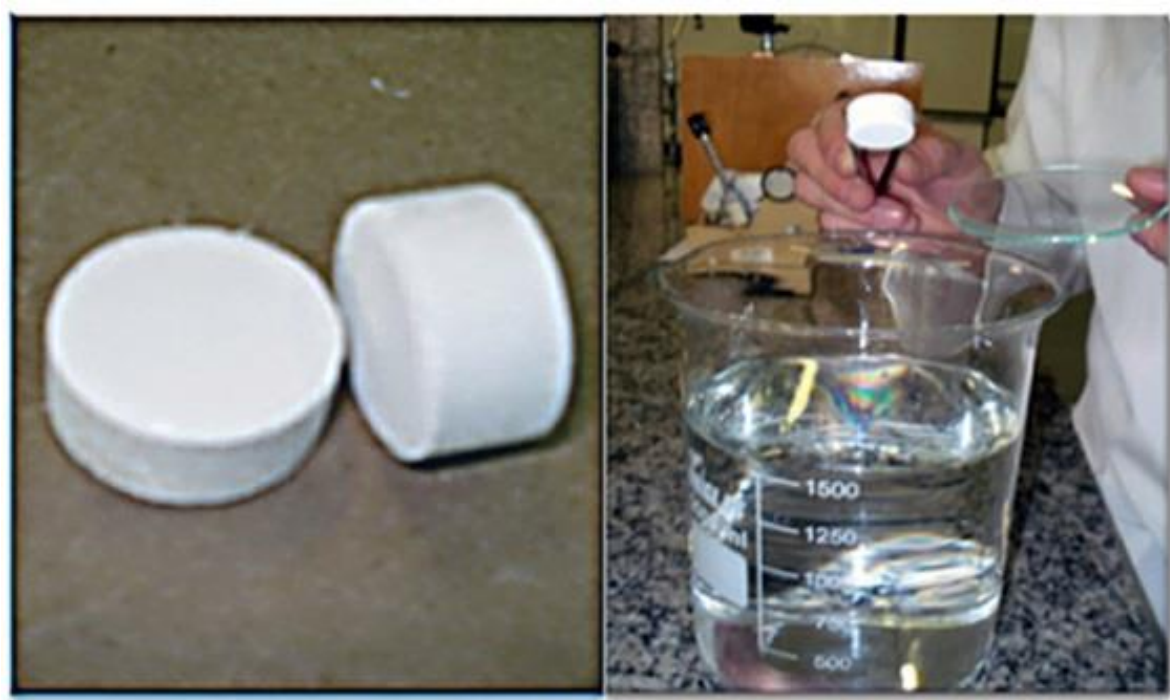

Figura 65: Modelo das pastilhas produzidas. 


\section{REFERÊNCIAS BIBLIOGRÁFICAS}

ABDEL-RAHMAN, M. S. The presence of trihalomethanes in soft drinks. Journal of Applied Toxicology, v.2, n.3, p.165-166, 1982.

ABICLOR. Setor cloro-soda. Disponível em: <http://www.quimica.com.br/pquimica/ quimica-2/cloro-soda-setor-pede-energia-com-preco-menor/>Acesso em 15 junho de 2013.

ABIPLA. Consumo e faturamento de produtos de limpeza. Disponível em: <http://www.abipla.org.br/novo/anuario.aspx>. Acesso 15 junho 2013.

ACNielsen. Produtos a base de cloro. Disponível em: <http://www.freedom.inf.br/revista/ hc33/destsazo_holsehold_sesforco.asp>. Acesso em 15 junho 2013.

ANDRADE, N.J.; MACÊDO, J. A.B. Higienização na indústria de alimentos. São Paulo.: Varela, 1996. p.182.

ANDRADE, M. H. S. Estudo e Otimização da Fluidodinâmica do Anólito de Celas de Cloro-Soda com Tecnologia de Diafragma, Tese de Doutorado, Universidade Federal de Campina Grande, Brasil, 2006.

ASSOCIAÇÃO BRASILEIRA DE NORMAS TÉCNICAS. Sistemas prediais de esgoto sanitário: Projeto e execução. Rio de Janeiro: ABNT, 1999. (NBR 8160). Disponível em: $<$ http://www.grupoanpla.com.br/Infraestrutura/arquivos/nbr/Sistemas_Prediais_de_Esgoto _Sanitario_-_Projeto_e_Execucao_NBR_08160_-_1999.pdf> Acesso em: 20 mai. 2013.

ASSOCIAÇÃO BRASILEIRA DE NORMAS TÉCNICAS. Aparelhos sanitários de material cerâmico: Dimensões padronizadas: Procedimento. Rio de Janeiro: ABNT, 2004. (NBR 15099).

BALSTER, R. L., BORZELLECA. J. F. Behavioral toxicity of trihalomethane contaminants of drinking water in mice. Environmental Health Perspectives, v.46, p.127-136, 1982.

BARROS, N.B.; SCARMINIO, I.S.; BRUNS, R.E. Como fazer experimentos: Pesquisa e desenvolvimento na ciência e na indústria. 4.ed. Bookman.: Porto Alegre, 2010.

BAYER, Pesquisa de Opinião Pública: Preferência entre dois agentes descontaminantes usados para água de consumo. Higiene Alimentar, v.13, n.63, 9p., Jul/Agosto 1999.

BELLAR, T.A., LICHTENBERG, J. J., KRONER, R. C. The ocurrence of organohalides in chlorinated drinking waters. Journal American Water Works Association, v.66, n.12; p.703-706, Dec. 1974.

BOX, G.; E. P. et al. Statistics for experimenters. Design, Innovation and Discovery. 2.d. New York, 2005.

BUN, W. W., HAAS, B. B., DEANE, E. R. et al. Formation of trihalomethanes by chlorination of surface water, Environmental Letters, v.10, n.3, p.205-213, 1975. 
BRASIL. Leis, decretos, etc... Portaria n 36, de 19 de janeiro de 1990, Normas e padrão de potabilidade da água destinada ao consumo humano. Diário Oficial [da República Federativa do Brasil], Brasilia, v.128, n.16, p.1651-1654, 23 jan. 1990. Secção 1.

BRASIL. Leis, decretos, etc... Portaria n 1469, de 29 de dezembro de 2000, Estabelece os procedimentos e responsabilidades relativos ao controle e vigilância da qualidade da água para consumo humano e seu padrão de potabilidade e dá outras providências. Diário Oficial [da República Federativa do Brasil], Brasilia, n.14E, 19 jan. 2001. Secção 1.

BRASIL. Ministério das Cidades. Instituto de Planejamento Econômico e Social. Sistema Nacional de Informações sobre Saneamento (SNIS). Diagnóstico dos serviços de água e esgotos 200, 2 v. Brasília: Secretaria Especial de Desenvolvimento Urbano da Presidência da República (SEDU-PR), 2007.

BRASIL. MINISTÉRIO DA SAÚDE. AGÊNCIA NACIONAL DE VIGILÂNCIA SANITÁRIA. Regulamento Técnico para Produtos com ação Antimicrobiana. Brasília: ANVISA, 2007. (RDC, n. 14). Disponível em: <http://portal.anvisa.gov.br/wps/wcm/connect/ a450e9004ba03d47b973bbaf8fded4db/RDC+14_2007.pdf?MOD=AJPERES>. Acesso em: 05 mai. 2013.

BRASIL. MINISTÉRIO DA SAÚDE. AGÊNCIA NACIONAL DE VIGILÂNCIA SANITÁRIA. Autoriza a inclusão da substância ácido dicloroisocianúrico e seus sais de sódio e potássio para desinfecção de água para consumo humano. [s.I.: s.n.]: ANVISA, 1999. (RDC, n.150).

BRASIL. MINISTÉRIO DA SAÚDE. AGÊNCIA NACIONAL DE VIGILÂNCIA SANITÁRIA. Aprova o regulamento técnico para produtos destinados à desinfecção de água para 0 consumo humano e de produtos algicidas e fungicidas para piscinas. [s.I.: s.n.]: ANVISA, 1999. (RDC, n.152).

BRASIL. MINISTÉRIO DA SAÚDE. Portaria o 2914 de 12 de dezembro de 2011. Dispõe sobre os procedimentos de controle e de vigilância da qualidade da água para consumo humano e seu padrão de potabilidade.

BRASIL. MINISTÉRIO DO DESENVOLVIMENTO URBANO E MEIO AMBIENTE. Resolução n. 357. [s.I.: s.n.]: CONAMA, 2005. p. 58-63. (D.O.U. n. 053). Disponível em: <http://www.mma.gov.br/port/conama/res/res05/res35705.pdf>. Acesso em: 10 mai. 2013.

BRASIL. MINISTÉRIO DO DESENVOLVIMENTO URBANO E MEIO AMBIENTE. Resolução n. 430. [s.l.: s.n.]: CONAMA, 2011. p. 89. (D.O.U. n. 092). Disponível em: <http://www.mma.gov.br/port/conama/legiabre.cfm?codlegi=646> Acesso em: 12 mai. 2013.

BRASIL. INSTITUTO BRASILEIRO DE GEOGRAFIA E ESTATÍSTICA. Mulheres mais escolarizadas são mães mais tarde e têm menos filhos. [s.I.: s.n.]: IBGE, 2010. Disponível em: <http://saladeimprensa.ibge.gov.br/noticias?view=noticia\&id=1\&busca=1\&idnoticia= 1717> Acesso em: 14 mai. 2013.

BRIENT, T. F.; BOMMARAJU, T. V.; HINE, F. Handbook of Chlor-Alkali Tecnology, V.I, New York, Springer, 2005.

BUENO, F.B.A. et al. apud. Avaliação de Técnicas para Tratamento da Urina Humana. $23^{\circ}$ Congresso Brasileiro de Engenharia Sanitária e Ambiental. 2005. São Carlos, SP.

CARSWELL, J. K., CLARK, M. R., DORSEY, P. et al. Ozone, chlorine dioxide and chloramines as alternatives to chlorine for disinfection of drinking water. In: 
CONFERENCE ON WATER CHLORINATION: Environmental Impact and Health Effects, 2, 1977, Gatlinburg. Anai. Gatlinburg: Office of Research and Development U. S. Environmental Protection Agency - EPA, 1977. p.1-84.

CERVESIA. Dióxido de cloro. Disponível em: <http://www.cervesia.com.br/cip-limpeza-edesinfeccao/146-a-utilizacao-de-dioxido-de-cloro-na-industria-de-bebidas.html>. Acesso 15 junho 2013.

CETESB. Técnicas de Abastecimento e Tratamento de Águas. Volume II. CETESB/ASCETESB. 2aㅡ ed. 1988.

CLEARON. Acid Granular Cyanuric: technical product bulletin. New York.: Clearon Corp, 1997. p. 22.

CHOPRA, S.; PATIL, G.V.; MOTWANI, S.K. apud. Release Modulating Hydrophilic Matrix Systems of Losartan Potassium: Optimization of Formulations Using Statistical Experimental Desgin. European Journal of Pharmaceutics and Biopharmaceutics 60, 2007. p. 73-82.

DAE. DEPARTAMENTO DE ÁGUA E ESGOTO DE JUNDiAí. Decreto Municipal n. 24.162. Jundiaí.: São Paulo, 2012. Disponível em: <http://www.daejundiai.com.br/daesite/ biblio.nsf/V03.01/legislacao_municipal/\$file/Decreto24162-2012.pdf> Acesso em: 02 jun 2013.

DECA. PRODUTOS SANITÁRIOS. Disponível em http://www.deca.com.br/. Acesso em: 05 dez 2012.

DYCHDALA, G.R. Chlorine and chlorine compounds. In: BLOCH, S. S. (Ed.) Disinfection, sterilization and preservation, 2. ed. Philadelfia, Lea \& Febiger, 1977. p. 167-195.

FERNANDES, E.; GLÓRIA, A. M. S.; GUIMARÃES, B. A. O Setor de Soda-Cloro no Brasil e no Mundo, BNDES Setorial, 2009, 29, 279-320.

FERREIRA FILHO, S. S., Remoção de compostos orgânicos precursores de subprodutos da desinfecção e seu impacto na formação de trihalometanos em águas de abastecimento. Revista Engenharia Sanitária e Ambiental, v.6, n.1 e 2, p.53-60, Jan/Junho 2001.

FREEDOM. Água sanitária. Disponível em:<http://www.freedom.inf.br/revista/hc61/ alvejantesAguaSanitaria.asp>.Acesso 15 junho 2013.

FURLANETTO, S. et al. Study of Formulation Variables Influencing the Drug Release Rate from Matrix Tablets by Experimental Design. European Journal of Pharmaceutics and Biopharmaceutics 62, 2005, p. 77-84.

GENCO, Fichas de dados de segurança de materiais - Hipoclorito de cálcio. SÃO PAULO: Genco Química Industrial Ltda. 7p. Setembro/1998.

GRAY, N. F. Calidad del agua potable. Zaragoza: Acribia, 1994. 365p.

GONÇALVES, R. F. (Coord.). Uso racional da água em edificações. ed. Rio de Janeiro: Prosab/Abes, 2006.

HIDROALL, HCL60 - Ácido tricloro isocianúrico. CAMPINAS; HidroAll Ltda. 19p., Setembro/2000a. 
HIDROALL, HCL90 E HCL56 - Dicloroisocianurato de sódio. CAMPINAS: HidroAll Ltda. 19p., Dezembro/2000b.

JOHNSON, J. D., JENSEN, J. THM and toxicity formation - routes, rates and precursores. In: AWWA Seminar Proceedings Strategies for the Control of Trihalomethanes, 1983, Las Vegas. Anais.... Las Vegas: American Waters Works Association - AWWA, 1983. p.1-21.

MACÊDO, J. A. B., Determinação de Trihalometanos em Águas de Abastecimento Público e Indústria de Alimentos. Viçosa, MG. 90p. Dissertação (Doutorado em Ciência e Tecnologia de Alimentos) - Universidade Federal de Viçosa, 1997.

MACÊDO, J.A.B. Águas \& Águas. Belo Horizonte.: Ortfofarma, 2000. p. 505.

MACÊDO, J. A. B., Subprodutos do Processo de Desinfecção de Água pelo Uso de Derivados Clorados (Disinfection byproducts - DBP). Juiz de Fora: Macedo, 67p. 2001.

MACÊDO, J. A. B.; BARRA, M.M. Derivados Clorados de origem orgânica uma solução para o processo de desinfecção de água potável e para desinfecção de industrias. VI Simpósio Ítalo Brasileiro de Engenharia Sanitária e Ambiental. Vitória, 2002.

MAcNEAL, T. P., HOLLIFIELD, H. C., DIACHENKO, G. W., Survey of trihalomethanes and other volatile chemical contaminants in processed foods by purge-and-trap capillary gas chromatography with mass selective detection. Journal of AOAC International, v.78, n.2, p.391-397, 1995.

MARTINELLO, T. et al. Optimization of Poorly Compactable Drug Tablets Manufactured by Direct Compression Using the Mixture Experimental Design. International Journal of Pharmaceutics 322, 2006. p. 87-95.

MARRIOT, N.G. Principles of food mi-crobiology. New York. : Chapman \& Hall, 1995. p. 421.

MELNICK, R. L. Toxicology and Carcinogenesis studies or Bromodicholoromethane. Washington, D.C.:US. Departament of Health and Human services, 1987. 182p.

MELNICK, R. L. Toxicology and carcinogenesis studies or tribromethane (bromofórmio). Washington, D.C.: U.S. Departament of Health and Human Services, 1989. 194p.

THE MERCK IDEX, 14ed. Editor Merck Research Laboratories, 2006.

TOMINAGA, M. Y., MIDIO, A. F. Expoxição humana a trihalometanos presentes em água tratada. Revista de Saúde Pública, v.33, n.4, p.413-421, Agosto 1999.

McPHERSON, L. L. Understanding ORP"S role in the disinfection process. WATER/ Engineering \& Management, v.11, p.29-31, Nov. 1993.

MEYER, S.T. O uso do cloro na desinfecção de águas, a formação de trihalometanos e os riscos potenciais à saúde pública. Caderno Saúde Pública, 1994. v. 10. n. 1. p. 99-110.

MORAIS, L.C. Caracterização do lodo de esgoto calcinado e sua utilização como agente filtrante no tratamento de água de abastecimento. 2009. Tese (Pós-Doutorado) Departamento de Engenharia Química EPUSP, São Paulo.

MORAIS, L.C. Caracterização em escala de laboratório, do produto proveniente da calcinação do lodo de esgoto resultante do tratamento de águas residuárias. 2006. Tese (Doutorado) - Escola Politécnica-USP. p.120. 
NAES, T.; FAEGESTAD, E.M.; CORNELL, J. A. Comparison of Methods for Analyzing data Froma a Three Component Mixture Experiment in the Presence of Variation Created by two Process Variables. Chemometrics and Intelligent Laboratory Systems 41, 1998. p. 221-235.

NASCIMENTO, F.; D'artagnan,G. Dicloroisocianurato de sódio, derivado clorado de origem orgânica uma solução economicamente viável para o processo de desinfecção de água potável. Estudo de caso BA USA-Sistema integrado Paraguassu Milagres. In: 230 Congresso Brasileiro de Engenharia Sanitária e Ambiental, 18-23 setembro 2005, Campo Grande, MS.

NASCIMENTO, M.S.; SILVA, N. apud. Tratamentos químicos na sanitização de morango (Fragaria vesca L). Braz. J. Food Technol, 2010. v.13. n.1. p.11-17.

NETO, B.B.; SCARMINIO, I.S.; BRUNS, R.E. Como Fazer Experimentos: Pesquisa e Desenvolvimento na Ciência e na Indústria. 4 ed. Porto Alegre, Bookman, 2010.

NORIEGA, P. et al. apud. Optimization of Pothomorphe umbellata (L.) Miquel formulações tópicas utilizando deliniamento experimental. International Journal of Pharmaceutics, 2008. v. 353. p. 149-159.

NSF. NSF Certified Products - Public Water Supply Treatment Chemicals. Capturado em 09/04/2002. Online. Disponível na Internet em http:/www.nsf.org/Certified/PwsChemicals/ Listings .asp? Company $=34810 \&$ Standard $=060$

ORGANIZAÇÃO DAS NAÇÕES UNIDAS. Millennium Project. Investing in development: a practical plan to achieve the Millennium Development Goals. New York: 2005.

OKAMURA, E.K. apud. Economia de água em bacias sanitárias. Curso de Graduação Faculdade de Engenharia Elétrica e de Computação/ UNICAMP. Revista Ciência do Ambiente On-Line, 2006. v. 2. n.1.

OXYCHEM. ACL 90EUP Chloraniting Composition. Dallas: Occidental Chemical Corporation. 20p., 2001.

PERUZZO, T.M.; CANTO, E.L. abut. Coleção base: Química. São Paulo. Moderna, 1999.

PROSAB. Programa de Pesquisas em Saneamento Básico. Edital 05. Conservação de água e energia em sistemas prediais e públicos de abastecimento de água. Ricardo Franci Gonçalves (coordenador). Rio de Janeiro: ABES, 2009.

RODRIGUES, L. C. S. Avaliação da eficiência de dispositivos economizadores de água em edifícios residenciais em Vitória-ES. Dissertação (Mestrado) - Programa de PósGraduação em Engenharia Ambiental da Universidade Federal do Espírito Santo, Vitória, 2005.

ROOK, J., EVANS, S., Renoval of trihalomethane precursores from surface waters using weak base resins. Journal American Water Works Association, v.9, n.71, p.520-524, 1979.

SÃO PAULO (Estado). Decreto n. 8468, de 8 de setembro de 1976. Aprova o Regulamento da Lei n. 997, de 31 de maio de 1976, que dispõe sobre a Prevenção e Controle da Poluição do Meio Ambiente. Disponível em <http://www.cgu.unicamp.br/ residuos/doctos/Decreto_8468_1976.pdf>. Acesso em: 22 mai 2013. 
SAMPAIO PEREIRA, A. M., Detecção espectrofotométrica de trihalometanos em águas de abastecimento público. Porto Alegre: UFRGS, 1989. 141p. Dissertação (Mestrado em Engenharia Civil). Universidade Federal do Rio Grande do Sul, 1989.

SANTOS FILHO, D. F. S. Tecnologia de tratamento de água. São Paulo : Nobel, 1985. p. 251.

SAVITZ, A. W. The Triple Bottom Line: How Today's Best-Run Companies are Achieving Economic, Social, and Environmental Success. San Franscisco, CA, Jossey-Bass/Wiley, 2006.

SHIN, S. et al. Time-Oriented Experimental Design Method to Optimize Hydrophilic Matrix Formulations With Gelation Kinetics and Drug Release Profiles. International Journal of Pharmaceutics, 2011. v. 407. p. 53-62.

SILVA, N. et al. Ocorrência de Escherichia Coli O157:H7 em vegetais e resistência aos agentes de desinfecção de verduras. Cienc. Tecnol. Aliment, 2003. v. 23. n. 2. p. 167173.

SYMONS, J. M., STEVENS, A. A., CLARK, R. M. et al., Treatment techniques for controlling trihalomethanes in drinking water. Cincinnati: U.S. Environmental Protection Agency, 1981. 289p.

TCHOBANOGLOUS, G.; BURTON, F.L. Wastewater engineering: treatment, disposal and reuse. 3. ed. New York.: McGraw Hill, 1991. p.1335.

UNDP. Human development report, beyond scarcity: Power, poverty and the global water crisis. [s.l.], 2006.

YOON, J., JENSEN, J. N. Chlorine transfer from inorganic monochloramine in chlorinated wastewater. Water Environment Research, v.67, n.5., p.842-847. July/Aug. 1995.

ZANCHETA, P.G. Recuperação e tratamento da urina humana para uso agrícola. 2007. Dissertação (Mestrado) - Universidade Federal do Espírito Santo, Vitória. p. 83. 


\section{ANEXOS}

\section{APÊNDICE 1}

\section{TERMO DE CONCORDÂNCIA}

Eu

RG.

Endereço , n

Cidade , Estado

Telefone

Declaro para os devidos fins, que participarei voluntariamente dos testes referentes ao desenvolvimento de um produto saneante para minimizar o consumo de água em descargas de urina em vasos sanitários, conforme descrito no projeto de pesquisa conduzida pelo aluno Antonio César Teixeira de Toledo que realiza mestrado no IPEN-SP - instituto de pesquisas energéticas e nucleares. Os testes serão feitos com o produto em minha residência com a adição diretamente ao vaso sanitário após a micção.

Estou ciente que meu nome e os resultados do mesmo poderão ser publicados para consultas em internet e outros meios de divulgação. (assinatura do voluntário)

Nome do Voluntário:

Antonio César Teixeria de Toledo (Responsável pela Pesquisa)

Data e Local: 
APÊNDICE 2

FICHA DE AVALIAÇÃO SENSORIAL DE PRODUTO

Participante voluntário:

Idade:

Sexo: ( ) Masculino ( ) Feminino

Fórmula do produto avaliado: ( ) FM1 - ( ) FM2 - ( ) FM3

\begin{tabular}{|c|c|c|c|c|c|c|}
\hline & \multicolumn{5}{|c|}{ Notas } \\
\hline Características & $\begin{array}{c}\text { Ótimo } \\
(9 \text { a 10) }\end{array}$ & $\begin{array}{c}\text { Muito bom } \\
\text { (7 a 8) }\end{array}$ & $\begin{array}{c}\text { Bom } \\
\text { (5 a 6) }\end{array}$ & $\begin{array}{c}\text { Ruim } \\
\text { (3 a 4) }\end{array}$ & $\begin{array}{c}\text { Péssimo } \\
\text { (0 a 2) }\end{array}$ & $\begin{array}{c}\text { Total } \\
\text { Geral }\end{array}$ \\
\hline ODOR & & & & & \\
\hline Espuma & & & & & \\
\hline Transparência & & & & & \\
\hline Sólidos & & & & & \\
\hline
\end{tabular}

Qual dos atributos acima você considera mais importante?

$\begin{array}{ccccc}\text { Cor } & \text { Odor } & \text { Espuma } & \text { Transparência } & \text { Presença de Sólidos } \\ \text { ( ) } & (\text { ) } & (\text { ) } & (\text { ) } & \text { ( ) }\end{array}$

